\title{
Addendum to the Post-Closure Permit Application for the Bear Creek Hydrogeologic Regime at the Y-12 Plant: Walk-In Pits
}

APRIL 1995

Prepared for

MARTIN MARIETTA ENERGY SYSTEMS, INC.

Oak Ridge, Tennessee

Prepared by

Geraghty \& Miller, Inc.

97 Midway Lane

Oak Ridge, Tennessee 37830

(615) $481-3000$

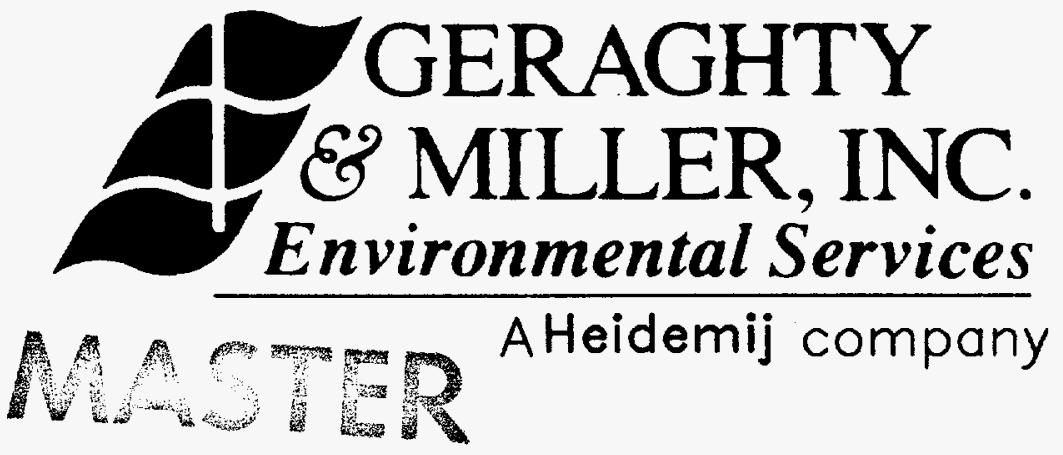




\section{DISCLAMIER}

Portions of this document may be illegible in electronic image products. Images are produced from the best available original document. 


\author{
ADDENDUM TO THE \\ POST-CLOSURE PERMIT APPLICATION \\ FOR THE BEAR CREEK HYDROGEOLOGIC REGIME \\ AT THE Y-12 PLANT: \\ WALK-IN PITS
}

\author{
Document Prepared by \\ GERAGHTY \& MILLER, INC. \\ 97 Midway Lane \\ Oak Ridge, Tennessee 37830 \\ under Subcontract 12Y-ALV96C
}

for the

\title{
U.S. Department of Energy
}

Office of Environmental Restoration and Waste Management under budget and reporting code EW20

Oak Ridge Y-12 Plant

Oak Ridge, Tennessee 37831-8169 managed by

MARTIN MARIETTA ENERGY SYSTEMS, INC.

for the U.S. DEPARTMENT OF ENERGY

Under Contract No. DE-AC05-84OR21400 


\section{FORWARD}

In June 1987, the Resource Conservation and Recovery Act (RCRA) Closure/Post-Closure Plan for the Bear Creek Burial Grounds (BCBG) was submitted to the Tennessee Department of Environment and Conservation (TDEC) (formerly known as the Tennessee Department of Health and Environment) for review and approval. The TDEC modified and issued the approved plan on September 30, 1987. Subsequently, this plan was modified again and approved as the Revised RCRA Closure Plan for the Bear Creek Burial Grounds (Martin Marietta Energy Systems, Inc. 1988).

The revised Closure Plan was initially intended to apply to A Area, C-West, B Area, and the Walk-In Pits (WIPs) of the BCBG. However, a strategy was developed to include the B Area [a solid waste management unit (SWMU)] with the WIPs so that both areas would be closed under one cap. The plan was presented to the State of Tennessee on March 8, 1990, and the Department of Energy was requested to review other unique alternatives to close the site. Therefore, in November 1992, the Closure Plan for B Area and the WIPs was prepared separately from that of the other sites associated with the BCBG and was presented in a RCRA Closure Plan (Martin Marietta Energy Systems, Inc. 1992).

In January 1993, the Closure Plan was revised (Martin Marietta Energy Systems, Inc. 1993a) to include inspection and maintenance criteria and to reflect that future monitoring and remediation would be conducted as part of the ongoing Comprehensive Environmental Response, Compensation, and Liability Act activities at the Oak Ridge Y12 Plant. The Closure Plan revision issued April 1993 (Martin Marietta Energy Systems, Inc. 1993b) was intended to reflect the placement of the Kerr Hollow Quarry debris at the WIPs, revise the closure dates, and acknowledge that the disposition of a monitoring well within the closure site could not be verified. 
In June 1994, a Post-Closure Permit Application (PCPA) for the BCBG was submitted to the TDEC (Geraghty \& Miller, Inc. 1994). This PCPA was to include the WIPs; however, at the time of submittal, closure of the WIPs had not been certified.

This addendum contains information on the WIPs to accompany the BCBG PCPA. The purpose of this document is to supplement the information provided in the BCBG PCPA. This document is not intended to be a stand-alone document. Only additional information regarding the WIPs is included in the sections of this document, which correspond to sections of the PCPA submitted in June 1994. 


\section{CONTENTS}

Page

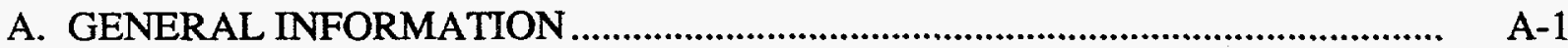

A.1 FACILITY DESCRIPTION...................................................................... A-1

A.1.1 Waste Disposal Units ..................................................................... A-1

A.1.2 Waste Disposal History ....................................................................... A-1

A.2 WASTE CHARACTERIZATION........................................................ A-2

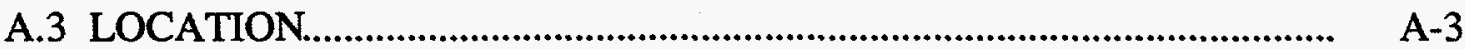

A.4 SECURITY PROCEDURES ........................................................................ A-3

A.5 INSPECTION SCHEDULE ...................................................................... A-3

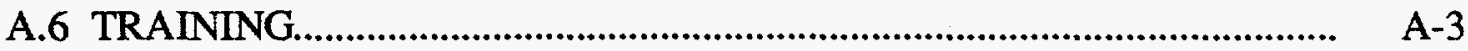

A.7 CLOSURE AND POST-CLOSURE PLAN ……........................................ A-3

A.8 NOTICES REQUIRED FOR DISPOSAL FACILITIES.............................. A-4

A.9 CLOSURE AND POST-CLOSURE COST ESTIMATES.............................. A-4

A.10 TOPOGRAPHIC MAP .................................................................... A-4

A.11 LIABILITY INSURANCE ............................................................. A-4

A.12 POST-CLOSURE CONTACT.......................................................... A-4

B. GROUNDWATER INFORMATION.......................................................... B-1

B.1 SUMMARY OF INTERIM STATUS DATA ............................................ B-1

B.1.1 Monitor-Well Network.................................................................. B-1

B.1.2 Groundwater Sampling and Analysis.......................................... B-1

B.2 HYDROGEOLOGIC FRAMEWORK …............................................ B-1

B.2.1 Regional Geology......................................................................... B-1

B.2.2 Stratigraphic Units......................................................................... B-1

B.2.3 Structural Relationships............................................................ B-1 
B.2.4 Surface-Water System............................................................... B-1

B.2.5 Groundwater System................................................................. B-2

B.3 POST-CLOSURE WASTE-MANAGEMENT AREA.................................. B- B-2

B.4 CONTAMINANT PLUME DESCRIPTION............................................... B-. B-2

B.4.1 Appendix IX Sampling Results ................................................... B-2

B.4.2 Distribution of Contaminants.................................................... B-2

B.4.3 Rate of Migration of Contaminants in Groundwater..................... B-2

B.5 GROUNDWATER PROTECTION........................................................... B-2

B.5.1 General Groundwater Monitoring Requirements........................... . B-3

C. CERTIFICATION .......................................................................................... C-1

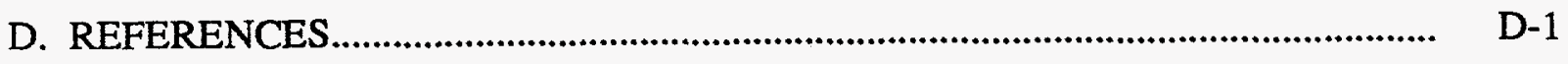

\section{APPENDICES}

A. RCRA Closure/Post-Closure Plan for the Bear Creek Burial Grounds B Area and Walk-In Pits

A.1 Revised RCRA Closure Plan

A.2 Post-Closure Plan

A.3 Closure Certification Letter

B. Well-Construction Diagrams

C. Applicable Standard Practice Procedures for the Groundwater Protection Program

C.1 Well Plugging and Abandonment Procedure

C. 2 Well Inspection Procedure

C.3 Well Depth Measurement Procedure

D. Sampling and Environmental Support Department Operating Procedure Groundwater Sampling 


\section{PLATES}

\section{A-1 Department of Energy Oak Ridge Reservation}

\section{A-2 Walk-In Pits and Burial Grounds Hazardous-Waste Disposal Unit}

\section{A-3 Survey Plat of the Walk-In Pits}

\section{DISCLAIMER}

This report was prepared as an account of work sponsored by an agency of the United States Government. Neither the United States Government nor any agency thereof, nor any of their employees, makes any warranty, express or implied, or assumes any legal liability or responsibility for the accuracy, completeness, or usefulness of any information, apparatus, product, or process disclosed, or represents that its use would not infringe privately owned rights. Reference herein to any specific commercial product, process, or service by trade name, trademark, manufacturer, or otherwise does not necessarily constitute or imply its endorsement, recommendation, or favoring by the United States Government or any agency thereof. The views and opinions of authors expressed herein do not necessarily state or reflect those of the United States Government or any agency thereof. 


\section{ACRONYMS}

BCBG

dpm

DOE

HWDU

KHQ

PCPA

RCRA

TDEC

WIPs
Bear Creek Burial Grounds

disintegrations per minute

U.S. Department of Energy

Hazardous-Waste Disposal Unit

Kerr Hollow Quarry

Post-Closure Permit Application

Resource Conservation and Recovery Act

Tennessee Department of Environment and Conservation

Walk-In Pits 


\section{A. GENERAL INFORMATION}

\section{A.1 FACILITY DESCRIPTION}

The Walk-In Pits (WIPs) are located adjacent to the Bear Creek Burial Grounds (BCBG) B Area (Plates A-1 and A-2). The B Area consists of a series of trenches located in the center of the BCBG Hazardous Waste Disposal Unit (HWDU). The WIPs are located on the flank of a hill (Plate A-2) and are referred to as the North and South Pits.

\section{A.1.1 Waste Disposal Units}

When the Resource Conservation and Recovery Act (RCRA) Part A permit application was submitted, disposal areas in the BCBG that received hazardous waste after November 19, 1980, were given interim status. These included the WIPs (Martin Marietta Energy System, Inc. 1988). The WIPs are sloped-entrance trenches to allow for entry and controlled placement of waste into the pits. The B Area was included in the closure of the WIPs due to the configuration of the waste sites and their proximity to one another. The WIPs and B Area were closed in 1994 under one RCRA closure plan. Closure certification was received from TDEC on February 28, 1995 (Appendix A.3). The Closure Plan for the BCBG B Area and WIPs is presented in Appendix A.1.

\section{A.1.2 Waste Disposal History}

The BCBG WIPs were first used in 1966 for the disposal of uranium and thorium saw fines and other shock-sensitive materials. From 1968 until 1980, the area was also used for above-grade burial of acids, bases, and organics.

Packaging of these wastes included drums, cardboard boxes, and buckets. The explosion hazard of the waste buried in the WIPs limited the type of closure used. Therefore, the selected closure method differed from the closure method (i.e., concrete 
cover versus vegetative cover) used at other parts of the BCBG HWDU. B Area received depleted uranium, uranium oxides, and minor amounts of debris and inorganic salts.

\section{A.2 WASTE CHARACTERIZATION}

Wastes disposed of in the WIPs were left in place because attempts to remove these materials would pose potential harm to human health and the environment. The waste inventory in the WIPs includes:

- solid waste (such as wood, metal, paper, glass, and debris) contaminated with depleted uranium chips, metals, and oxides;

- uranium and thorium saw fines;

- shock-sensitive acids, bases, and organics; and

- Wastes from Kerr Hollow Quarry (KHQ).

$\mathrm{KHQ}$ waste is considered a non-hazardous residue from treatment operations at the quarry. The KHQ waste is contaminated with low levels of uranium (Martin Marietta Energy Systems, Inc. 1993b). Radiological surveys of the material from KHQ indicate contamination at an average activity of 20,000 and 40,000 disintegrations per minute (dpm) with a maximum of 7.1 million dpm. The KHQ waste was placed in dumpsters and B-25 boxes and overpacked in concrete vaults. The KHQ debris deposited at the WIPs consisted of (Lockwood Greene Technologies, Inc. 1994):

- shredded carbon and stainless steel;

- heterogeneous mixture of mud, rock, shredded plastic bags, and organic material such as wood and leaves;

- small lead pipes;

- possibly as much as 4 pounds of asbestos;

- uranium and uranium alloys;

- zirconium metal and metal shavings;

- crystals of white phosphorus; and

- 9 to 13 millimeter glass vials containing unknown material. 


\section{A.3 LOCATION}

The WIPs are located in the BCBG HWDU adjacent to B Area. The BCBG HWDU is located on the slopes of Pine Ridge and in the Bear Creek Valley (Plate A-2).

\section{A.4 SECURITY PROCEDURES}

After capping, the access roads in the vicinity of the WIPs were routed such that no road crosses any portion of the WIPs. Traffic is restricted from leaving the roadways by an existing 6 foot (ft) high, chain-link fence and gates between the roadways and the disposal areas. The area is routinely patrolled by security personnel.

\section{A.5 INSPECTION SCHEDULE}

In addition to inspections described in the Post Closure Permit Application (PCPA) for the BCBG (Geraghty \& Miller, Inc. 1994), the post-closure inspection program for the WIPs will focus on: settlement/subsidence in the cap and growth of unwanted vegetation. Inspections of the cap will be conducted quarterly, along with other components of the BCBG cap. Details of inspection are provided in the Post Closure Plan in Appendix A.2.

\section{A.6 TRAINING}

Refer to the PCPA for the BCBG (Geraghty \& Miller, Inc. 1994).

\section{A.7 CLOSURE AND POST-CLOSURE PLAN}

The Closure Plan for the BCBG B Area and WIPs is presented in Appendix A.1 (Geraghty \& Miller, Inc. 1993b). The Post-Closure Plan for the WIPs is presented in Appendix A.2. The purpose of the Post-Closure Plan is to identify and describe the activities that will be performed during the post-closure care period. This plan will be implemented and will continue throughout the post-closure care period. 


\section{A.8 NOTICES REQUIRED FOR DISPOSAL FACILITIES}

After closure of the WIPs, the U.S. Department of Energy (DOE) submitted to the Anderson County, Tennessee Zoning Authority a survey plat of the WIPs prepared and certified by a professional land surveyor licensed in the State of Tennessee (Plate A-3). A record of the types and quantity of waste disposed at the site was also submitted based upon the best available knowledge and records.

\section{A.9 CLOSURE AND POST-CLOSURE COST ESTIMATES}

Refer to the PCPA for the BCBG (Geraghty \& Miller, Inc. 1994).

\section{A.10 TOPOGRAPHIC MAP}

A topographic map of the WIPs is provided on Plate A-2.

\section{A.11 LIABILITY INSURANCE}

Refer to the PCPA for the BCBG (Geraghty \& Miller, Inc. 1994).

\section{A.12 POST-CLOSURE CONTACT}

Refer to the PCPA for the BCBG (Geraghty \& Miller, Inc. 1994). 


\section{B. GROUNDWATER INFORMATION}

\section{B.1 SUMMARY OF INTERIM STATUS DATA}

The BCBG HWDU, including the WIPs, was granted interim status under RCRA in December 1984. A summary of interim status data is presented in Section B.1 of the PCPA for BCBG (Geraghty \& Miller, Inc. 1994). This summary includes references to Appendices B, C, and D.

\section{B.1.1 Monitor-Well Network}

Refer to the PCPA for the BCBG (Geraghty \& Miller, Inc. 1994).

\section{B.1.2 Groundwater Sampling and Analysis}

Refer to the PCPA for the BCBG (Geraghty \& Miller, Inc. 1994).

\section{B.2 HYDROGEOLOGIC FRAMEWORK}

\section{B.2.1 Regional Geology}

Refer to the PCPA for the BCBG (Geraghty \& Miller, Inc. 1994).

\section{B.2.2 Stratigraphic Units}

Refer to the PCPA for the BCBG (Geraghty \& Miller, Inc. 1994).

\section{B.2.3 Structural Relationships}

Refer to the PCPA for the BCBG (Geraghty \& Miller, Inc. 1994).

\section{B.2.4 Surface-Water System}

Refer to the PCPA for the BCBG (Geraghty \& Miller, Inc. 1994). 


\section{B.2.5 Groundwater System}

Refer to the PCPA for the BCBG (Geraghty \& Miller, Inc. 1994).

\section{B.3 POST-CLOSURE WASTE-MANAGEMENT AREA}

A topographic map of the BCBG HWDU, including the WIPs, is provided on Plate A-2. The DOE Oak Ridge Reservation property line is illustrated on Plate A-1.

\section{B.4 CONTAMINANT PLUME DESCRIPTION}

Refer to the PCPA for the BCBG (Geraghty \& Miller, Inc. 1994).

\section{B.4.1 Appendix IX Sampling Results}

Refer to the PCPA for the BCBG (Geraghty \& Miller, Inc. 1994).

\section{B.4.2 Distribution of Contaminants}

Refer to the PCPA for the BCBG (Geraghty \& Miller, Inc. 1994).

\section{B.4.3 Rate of Migration of Contaminants in Groundwater}

Refer to the PCPA for the BCBG (Geraghty \& Miller, Inc. 1994).

\section{B.5 GROUNDWATER PROTECTION}

Because the WIPs are located within the BCBG HWDU, all groundwater monitoring for the WIPs will be conducted in accordance with the terms specified in Section B.5 of the PCPA for the BCBG (Geraghty \& Miller, Inc. 1994). 


\section{B.5.1 General Groundwater Monitoring Requirements}

All corrective action monitoring activities for the WIPs are described in Section B.5.1 of the PCPA for the BCBG (Geraghty \& Miller, Inc. 1994) and will be conducted upon issuance of a post-closure permit for the BCBG. 


\section{CERTIFICATION}

Ref: $1200-1-11-.07(2)(a) 10$

I certify under penalty of law that this document and all attachments were prepared under my direction and supervision in accordance with a system designed to ensure that qualified personnel properly gather and evaluate the information submitted. Based on my inquiry of the person or persons who manage the system and of those persons directly responsible for gathering the information, the information submitted is to the best of my knowledge and belief, true, accurate, and complete. I am aware that there are significant penalties for submitting false information, including the possibility of fine and imprisonment for knowing violations.

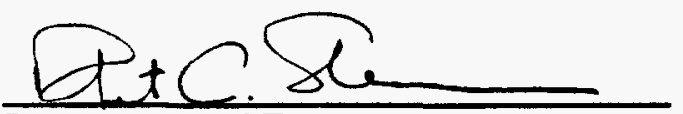

Deparment of Energy

Owner and Operator

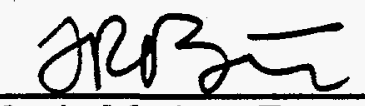

Martin Marietta Energy Systems, Inc. Co-Operator
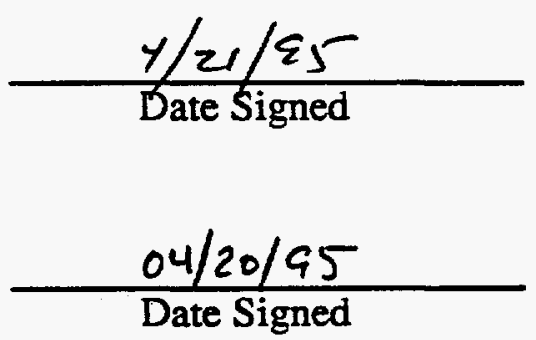

The Department of Energy and its operating contractor, Martin Marietta Energy Systems, Inc., have jointly signed this application as the operator of the permitted facility. The Department has determined that dual signatures best reflect the actual apportionment of responsibility under which the Department's RCRA responsibilities are for policy, programmatic, funding and scheduling decisions, as well as general oversight, and the contractor's RCRA responsibilities are for day-to-day operations, including but not limited to the following responsibilities: waste analysis and handling, monitoring, recordkeeping, reporting, and contingency planning. For purposes of the certification required by Tennessee Rule 1200-1-11-.07(2)(a)10, the Department's and Martin Marietta Energy Systems, Inc.'s, representatives certify, to the best of their knowledge and belief, the truth, accuracy and completeness of the application for their respective areas of responsibility.

This statement is attached hereto for the purpose of clarifying the roles and responsibilities of DOE and Energy Systems with respect to the permitted facility and it shall not be construed as altering or limiting the certification. 


\section{REFERENCES}

Geraghty \& Miller, Inc. 1994. Post-Closure Permit Application for the Bear Creek Hydrogeologic Regime at the Oak Ridge Y-12 Plant: Burial Grounds. Prepared for Martin Marietta Energy Systems, Inc. (Y/ER/SUB/91-ALV96/3, Rev. 2), June 1994.

Lockwood Greene Technologies, Inc. 1994. Summary Report, Bear Creek Burial Grounds "B" and the Walk-In Pits Closure Project. (Y/ER/02148). June 29, 1994.

Martin Marietta Energy Systems, Inc. 1988. Revised RCRA Closure Plan for the Bear Creek Burial Grounds. (Y/TS-395). February 29, 1988.

Martin Marietta Energy Systems, Inc. 1992. RCRA Closure Plan for the Bear Creek Burial Grounds B Area and Walk-In Pits at the Oak Ridge Y-12 Plant, Oak Ridge, Tennessee. DOE/OR/01-1100D1.

Martin Marietta Energy Systems, Inc. 1993a. RCRA Closure Plan for the Bear Creek Burial Grounds B Area and Walk-In Pits at the Oak Ridge Y-12 Plant, Oak Ridge, Tennessee. DOE/OR/01-1100D2.

Martin Marietta Energy Systems, Inc. 1993b. RCRA Closure Plan for the Bear Creek Burial Grounds B Area and Walk-In Pits at the Oak Ridge Y-12 Plant, Oak Ridge, Tennessee. (DOE/OR/01-1100\&D3 and Y/ER-539D3). April 1993. 
APPENDIX A

RCRA CLOSURE/POST-CLOSURE PLAN

FOR THE BEAR CREEK BURIAL GROUNDS

B AREA AND WALK-IN PITS

A.1 Revised RCRA Closure Plan

A. 2 Post-Closure Plan

A.3 Closure Certification Letter 
A.1 Revised RCRA Closure Plan 
LtT.FER/J-Y-93/022

Mast OFfaCE $80 \times 2000$

OAX RIOGE. TENMESSEE 37031

April 8, 1993

\author{
Ms. Sherry L. Lankford, Y-12 Program Manager \\ Environmental Restoration Division \\ DOE Oak Ridge Field Office \\ Post Office Box 2001
}

Oak Ridge, Tennessee 37830

Dear Ms. Lankford:

Transmittal of Revised Closure Plan for Bear Creek Burial Grounds B Area and Walk-In Pits at the Oak Ridge Y-12 Plant, Oak Ridge, Tennessee

Enclosed for your review and submittal to the Environmental Protection Agency and the Tennessee Department of Environment and Conservation are seven copies of:

DOE/ORJ01-1100\&D3 Revised Closure Plan for the Bear Creek Burial Grounds B Area and Walk-In Pits at the Oak Ridge Y-12 Plant, Oak Ridge. Tennessee.

The closure plan for the Bear Creek Burial Grounds (BCBG) B Area and Walk-In Pits (WIP) has been revised to reflect the disposition of the Kerr Hollow Quarry (KHQ) debris at the WIP unit, to revise the closure dates based on the current schedule, and to include the fact that well GW33 is inaccessible and can not be plugged. The design drawings are in the process of being modified to extend the geotextile fabric, geonet, geomembrane, and cover system over the KHQ debris.

The KHQ debris proposed for consolidation at the WIP consists of shredded carbon and stainless steels, a heterogenous mixture of mud. rock, shredded plastic bags, organics such as wood and leaves, minor lead pipes. possible as much as four pounds ot asbestos, uranium and uranium alloys. zirconium metal and metal shavings, crystals of white phosphorus, live ammunition, 9 and $17 \mathrm{ml}$ glass vials containing unknown material, and small sections of pipe or tubing with sealed or crimped ends that may contain unreacted material. Radiological surveys of the material indicate contamination at an average activity between 20,000 and $40,000 \mathrm{dpm}$ with a maximum of 7.1 million dpm.

The shredded debris represents a residue from the treatment in the quarry. The technology-based standard for nonwastewaters specified in the Land Disposal Resolution (LDR) (40 CFR 268.42) for all forms of DOO3 waste is deactivation. Appendix VI further defines acceptable deactivation technologies hased on the character of the D003 waste such as water reactive, reactive sulfide, expiosive, or other reactives. The DOO3 components of the KHQ waste are water reactives and other reactives. One of the water reactive treatment technologies listed in Appendix VI is controlled reaction with water. Shredding the material under water and subsequent rough handling of the debris met this technology-based standard. Small vials or other forms of waste may have survived this process. Based on visual of servations, KHQ operations estimates that less than one percent of the total treated waste volume remains potentially reactive. Based on this process knowledge, the treatment residue should be considered nonreactive and therefore not subject to LDR. However, due to the heterogeneous and physical nature of the waste, confirmatory sampling is difficult, and test procedures for reactive waste are undefined. Therefore characterization by sampling is unreliable for this waste stream. 
The proposal to consolidate the KHQ debris within the WIP also meets the seven criteria outlined in the recently promulgated Resource Conservation and Recovery Act (RCRA) regulations under Subpart $S$ for Corrective Action Management Units (CAMUs). The CAMU criteria and justification are outlined as follows:

1. The CAMU shall facilitate the implementation or reliable, effective, protective, and costeffective remedies;

Placement of the KHQ debris in the regulated unit of the BCBG B Area/WIP is protective of human heaith and the environment as the regulated unit will be subject to post closure care. It is also much more cost-effective than the design and operation of a facility to separate and react the one percent of the material that may remain reactive.

2. Waste management activities associated with the CAMU shall not create unacceptable risks to humans or to the environment resuiting from exposure to hazardous waste or hazardous constituents;

Movement of the debris and placement under the WIP cap does not create risk to humans or to the environment other than those associated with normal construction activities. These risk are lower than the risk associated with the building and operation of a tacility to separate and react the potentially harmful material.

3. The CAMU shall contain uncontaminated areas of the facility, only if including such areas for the purpose of managing remediation wastes is more protective than management of such wastes at contaminated areas of the facility;

The placement of the debris under the BCBG Area B WIP cap does not extend the limits of the already contaminated BCBG.

4. Areas within the CAMU where wastes remain in place after closure of the CAMU shall be managed and contained so to minimize future releases, to the extent practicable;

A potential hazardous component in the KHQ debris is D003 reactive material. The debris will be boxed and under the cap material such that future releases are mitigated.

5. The CAMU shall expedite the timing of remedial activity implementation, when appropriate and practicable;

The earliest completion time for building and operating a facility for separating and deactivating the material in the debris is December 1995. By dispositioning the KHQ waste at the WIP the KHQ closure can be completed this year.

6. The CAMU shall enable the use, when appropriate, of treatment technologies (including innovative technologies) to enhance the long-term effectiveness of remedial actions by reducing the toxicity, mobility, or volume of wastes that will remain in place after closure of the CAMU; 
The KHQ debris has undergone an innovative treatment by shredding under water. Should future technologies be developed for the treatment of the WIP waste that treatment would atso be appropriate to the KHQ debris.

7. The CAMU shall, to the extent practicable, minimize the land area of the facility upon which wastes will remain in place after closure of the CAMU;

The KHQ debris will be placed under the limits of the cap already proposed for the WIP, and no additional land will have to be disturbed. Movement of the debris from the KHQ site will minimize the area of land which will need to be restricted at the KHQ.

In summary, the proposed revisions in the enclosed closure plan are necessary to expedite a safe costeffective, and environmentally sound closure strategy. Obtaining State approval of this revised plan is requested by April 30, 1993, in order to meet critical path schedule items for the WIP closure. If you have any questions, please call me at 576-5706 or Jerome Miller at 574-3680.

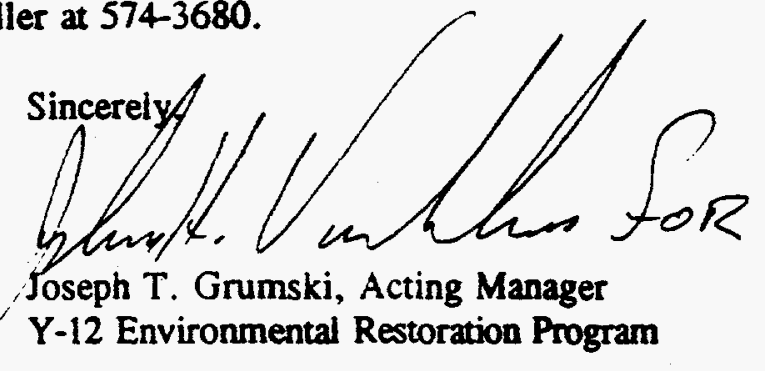

JTG:jmc

Enclosure

cilenc: E. T. Collins

C. D. Goins

J. E. Heiskell

R. M. Hill

C. C. Hill

J. Q. Miller

M. Mitchell

T. P. Perry

J. Powell, DOE-OR

J. K. Siberell

C. M, Smith

J. E. Stone

J. Kanderian

R. Oglesby, DOE-OR

File-ER Document Management Center-RC

File-Y-12 ER Program-NoRC 
I acknowledge receipt of the enclosed report and agree to transmit the appropriate number of copies to EPA and TDEC.

Sherry L. Lankford, Y-12 Program Manager

Date of Signature

DOE-OR Environmental Restoration Division 
RCRA Closure Plan for the Bear Creek Burial Grounds B Area and Walk-In Pits at the Oak Ridge Y-12 Plant, Oak Ridge, Tennessee

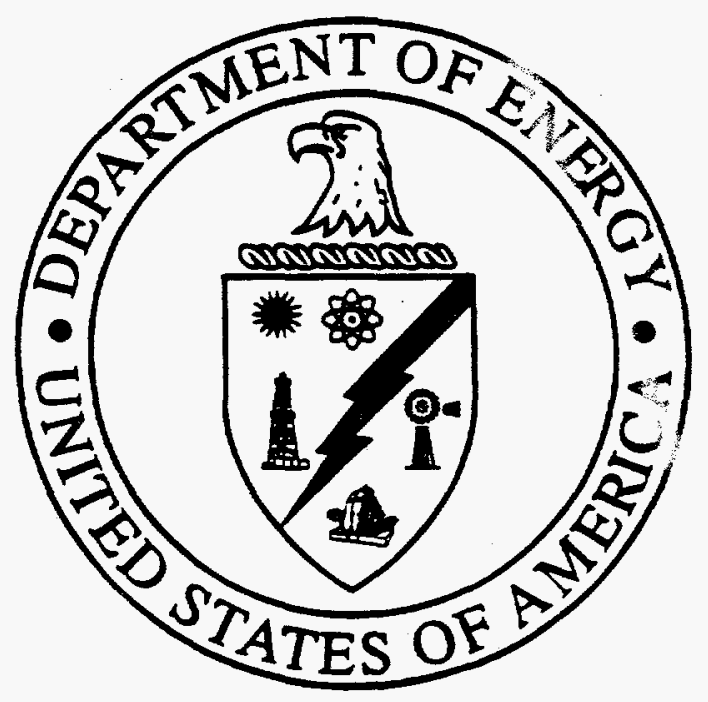


Energy Systems Environmental Restoration Program

Y-12 Environmental Restoration Program

RCRA Closure Plan for the Bear Creek

Burial Grounds B Area and Walk-In Pits

at the Oak Ridge Y-12 Plant, Oak Ridge, Tennessee

Date Issued-April 1993

Prepared for

U.S. Department of Energy

Office of Environmental Restoration and Waste Management under budget and reporting code EW 20

Prepared by the

OAK RIDGE Y-12 PLANT

managed by

MARTIN MARIETTA ENERGY SYSTEMS, INC.

for the

U.S. DEPARTMENT OF ENERGY

under contract DE-AC05-84OR21400 


\section{CONTENTS}

FOREWORD $\ldots \ldots \ldots \ldots \ldots \ldots \ldots \ldots \ldots \ldots \ldots \ldots \ldots \ldots \ldots \ldots \ldots \ldots \ldots \ldots$ iii

INTRODUCTION $\ldots \ldots \ldots \ldots \ldots \ldots \ldots \ldots \ldots \ldots \ldots \ldots \ldots \ldots \ldots \ldots \ldots \ldots$

CLOSURE PERFORMANCE STANDARDS $\ldots \ldots \ldots \ldots \ldots \ldots \ldots \ldots \ldots, 4$

WASTE INVENTORY $\ldots \ldots \ldots \ldots \ldots \ldots \ldots \ldots \ldots \ldots \ldots \ldots, 4$

EQUIPMENT DECONTAMINATION $\ldots \ldots \ldots \ldots \ldots \ldots \ldots \ldots \ldots \ldots, 5$

DESIGN ELEMENTS OF CLOSURE $\ldots \ldots \ldots \ldots \ldots \ldots \ldots \ldots \ldots \ldots$

INSTALLATION PROCEDURES $\ldots \ldots \ldots \ldots \ldots \ldots \ldots \ldots \ldots \ldots \ldots \ldots \ldots$

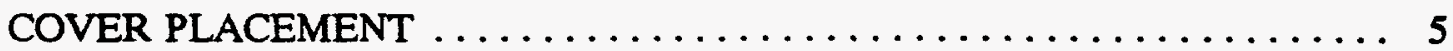

DRAINAGE AND EROSION $\ldots \ldots \ldots \ldots \ldots \ldots \ldots \ldots \ldots \ldots \ldots \ldots, 7$

ADDITIONAL CLOSURE ACTIVTTIES $\ldots \ldots \ldots \ldots \ldots \ldots \ldots \ldots \ldots \ldots$

CONSTRUCTION QUALITY ASSURANCE $\ldots \ldots \ldots \ldots \ldots \ldots \ldots \ldots \ldots, 8$

CONSTRUCTION DRAWINGS $\ldots \ldots \ldots \ldots \ldots \ldots \ldots \ldots \ldots \ldots \ldots, \mathbf{8}$

TRAFFIC CONTROL $\ldots \ldots \ldots \ldots \ldots \ldots \ldots \ldots \ldots \ldots \ldots \ldots, 9$

CLOSURE SCHEDULE ........................... 9

NOTICE TO LOCAL LAND AUTHORITY $\ldots \ldots \ldots \ldots \ldots \ldots \ldots \ldots, \mathbf{9}$

NOTICE IN DEED TO PROPERTY $\ldots \ldots \ldots \ldots \ldots \ldots \ldots \ldots \ldots, 10$

CLOSURE CERTIFICATION $\ldots \ldots \ldots \ldots \ldots \ldots \ldots \ldots \ldots \ldots \ldots \ldots \ldots \ldots \ldots \ldots \ldots$

OTHER ACTIVITIES $\ldots \ldots \ldots \ldots \ldots \ldots \ldots \ldots \ldots \ldots \ldots \ldots \ldots \ldots \ldots$

INSPECTION AND MAINTENANCE PLAN $\ldots \ldots \ldots \ldots \ldots \ldots \ldots \ldots, 10$

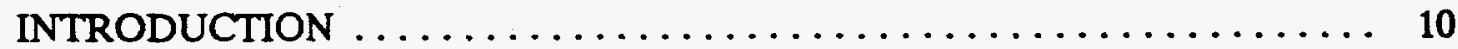

POTENTIAL POSTCLOSURE PROBLEMS $\ldots \ldots \ldots \ldots \ldots \ldots \ldots \ldots, 10$

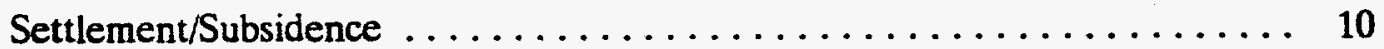

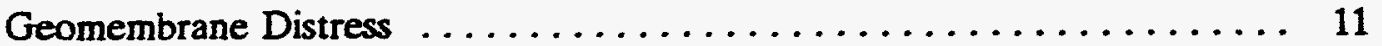

Uncontrolled Storm Runoff $\ldots \ldots \ldots \ldots \ldots \ldots \ldots \ldots \ldots \ldots \ldots \ldots$

POSTCLOSURE INSPECTION $\ldots \ldots \ldots \ldots \ldots \ldots \ldots \ldots \ldots \ldots \ldots, 11$

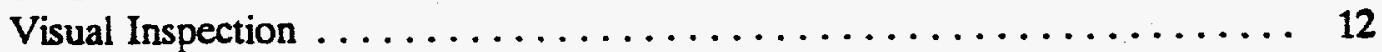

Subsidence Monitoring $\ldots \ldots \ldots \ldots \ldots \ldots \ldots \ldots \ldots \ldots \ldots \ldots, 12$

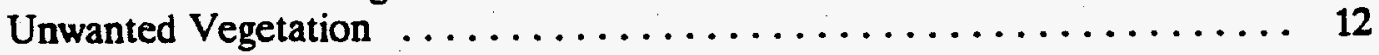




\section{FOREWORD}

In June 1987, the RCRA Closure/Postclosure Plan for the Bear Creek Burial Grounds (BCBG) was submitted to the Tennessee Department of Environment and Conservation (TDEC) (then known as the Tennessee Department of Health and Environment) for review and approval. TDEC modified and issued the plan approved on September 30, 1987. Subsequently, this plan was modified again and approved as Y/TS-395, Revised RCRA Clavere Plan for the Bear Creek Burial Grounds (February 29, 1988).

Y/TS-395 was initially intended to apply to A Area, C-West, B Area, and the Walk-In Pits of BCBG. However, a concept was developed to include the B Area (non-RCRA regulated) in the Walk-In Pits so that both areas would be closed under one cap. This approach included a tremendous amount of site preparation with an underlying stabilization base of $16 \mathrm{ft}$ of sand for blast protection. The plan was presented to the state of Tennessee on March 8, 1990, and the Department of Energy was requested to review other unique aiternatives to close the site. Therefore, the closure plan for B Area and the Walk-In Pits was prepared separately from that of the other burial grounds and was presented in DOE/OR/O1$1100 \& D 1$.

In January 1993, the Closure Plan (DOE/OR/01-1100\&D2) was revised to include inspection and maintenance criteria and to reflect that future monitoring and remediation would be conducted as part of the ongoing Comprehensive Environmental Response, Compensation, and Liability Act activities at the Oak Ridge Y-12 Plant.

This Closure Plan revision (DOE/OR/01-1100\&D3) is intended to reflect the placement of the Kerr Hollow Quarry debris at the Walk-In Pits, revise the closure dates, and acknowledge that the disposition of a monitoring well within the closure site cannot be verified. 


\section{INTRODUCTION}

The Bear Creek Burial Grounds (BCBG) are located on the southwest flank of Pine Ridge -1.5 miles west of the Oak Ridge Y-12 Plant in Bear Creek Valley. This facility consists of several contiguous disposal sites identified as Burial Grounds A, B, C, and D (see Figs. 1 and 2). Each burial site consists of a series of trenches used for disposal of solid wastes and, in some cases, liquid wastes. Trench bottoms are reported to be a maximum of $20 \mathrm{ft}$ below the original grade.

The first disposal trench in BCBG was excavated in August 1955 for the disposal of solid wastes. In July 1959, the Y-12 Plant was authorized by the Atomic Energy Commission to begin using this facility for the disposal of certain types of liquid wastes. Since that time, several types of wastes have been disposed of in the various burial ground areas, including the following (not listed in order of generated volume):

- ferrous metals and uranium,

- oils and coolants,

- salts,

- debris,

- solvents,

- ethylenediamine tetraacetic acid (EDTA),

- asbestos,

- material contaminated with radioisotopes, and

- mop water.

The actual quantity and identity of materials is uncertain, and other materials may have been disposed of that are not listed in any inventory. The largest volume of material disposed in BCBG consists of uranium-contaminated industrial trash (paper, wood, steel, glass, and rubble).

When RCRA Part A permit applications were submitted, trenches and disposal areas in BCBG that received hazardous waste after November 19,1980, were designated and given interim status. These RCRA trenches are identified in Fig. 2.

The B Area and the Walk-In Pits are located adjacent to each other in BCBG. The B Area consists of a series of trenches located on the crest of a hill in the center the BCBG. The Walk-In Pits are located on the side of this hill on the north and south sides of B Area (there are "north" and "south" Walk-In Pits).

The B Area was first used in 1962 for the disposal of depleted uranium chips, metals, and oxides. Because the chips were pyrophoric, chip fires were common. For a period of time in 1968 , chips were deliberately burned upon delivery in order to prevent unpredicted and unattended fires later. This practice was stopped soon after it was initiated, and unoxidized chips may remain in the covered trenches at present. 


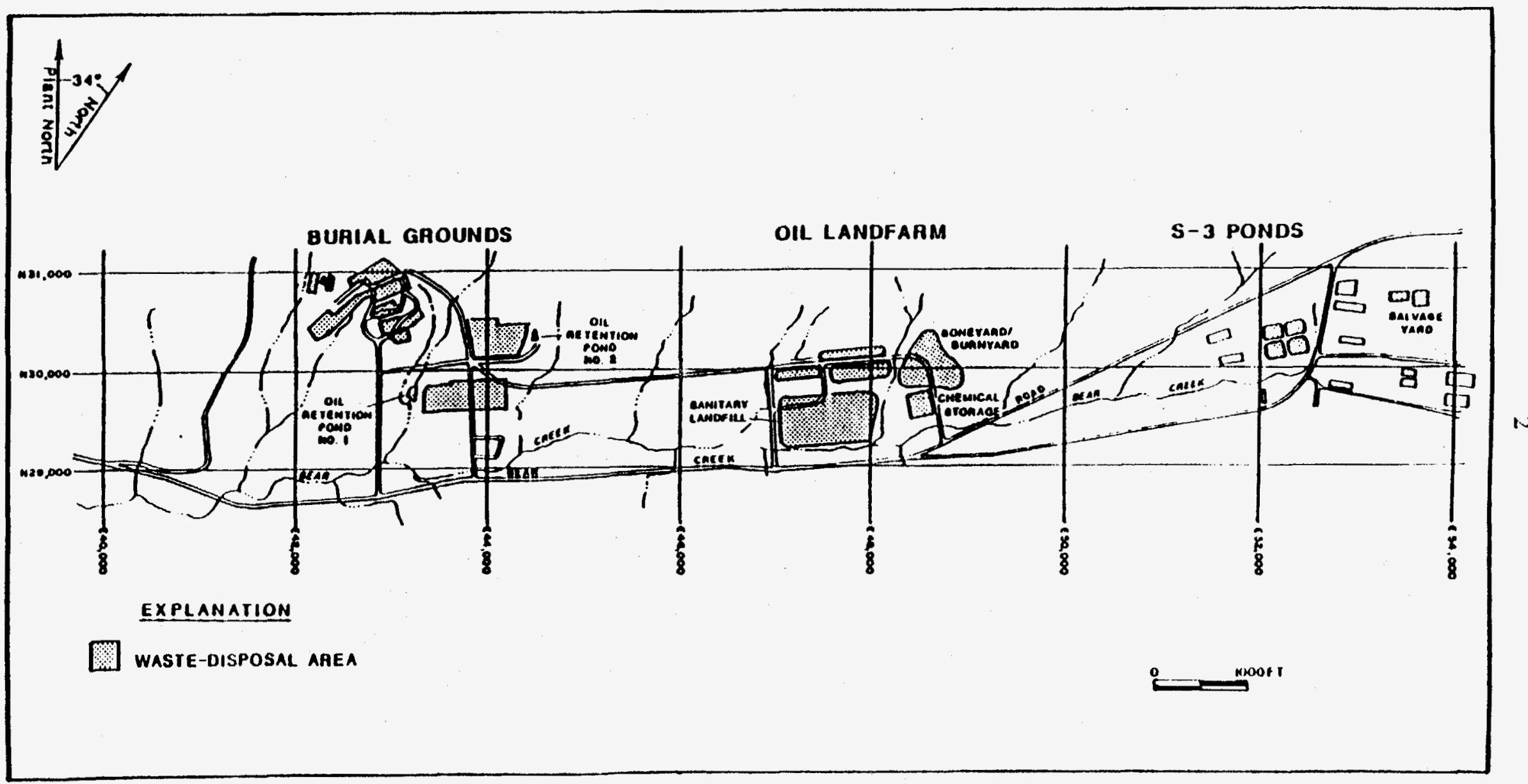

Fig. 1. Bear Creek Valley Waste Disposal Area. 


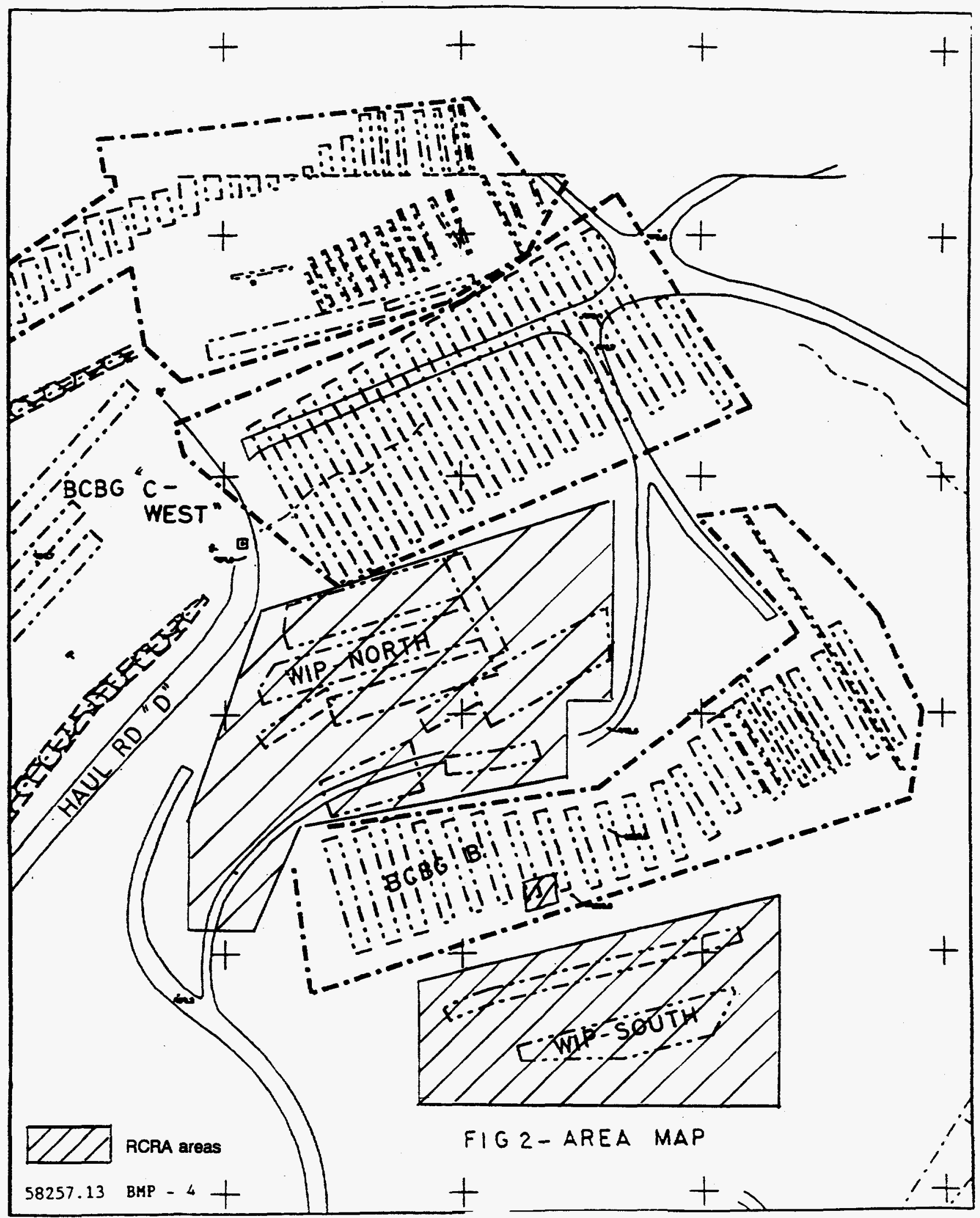

Fig. 2 Map of BCBG area showing B Area and Walk-In Pits. Hatched areas are RCRA; other areas are CERCLA only. 
The Walk-In Pits were first used in 1966 for the disposal of uranium and thorium saw fines and other shock-sensitive metals. From 1968 until 1980, the area was also used for the above-grade burial of acids, bases, and organics. Packaging of these wastes included drums, cardboard boxes, and buckets. The explosion hazard of the waste buried in the Walk-In Pits limits the types of closure activities which may be safely undertaken and is the main cause for changes in closure activities from those at the other parts of BCBG (such as A Area and CWest).

The Kerr Hollow Quarry debris is to be dispositioned under the BCBG B Area/WIP cap and is considered a nonhazardous residue from treatment operations at the quarry. The waste is contaminated with low levels of uranium.

\section{CLOSURE PERFORMANCE STANDARDS}

At closure, the BCBG B Area, the Walk-In Pits, and the Kerr Hollow Quarry debris will be covered with an engineered cap designed and constructed to minimize migration of liquids, promote drainage around the capped areas, and minimize erosion, subsidence, and maintenance. They will be closed in place in a manner that will reduce the need for postclosure maintenance. As a result of this closure, the potential for additional releases to the receiving stream and the groundwater will be reduced and controlled. Detailed descriptions of closure procedures are provided in the following sections.

Prior to construction, 10 of 11 groundwater sampling wells within the perimeter of the cap will be plugged and abandoned. One well, GW-033, cannot be investigated to verify its disposition, as it is located on the boundary of the north Walk-In Pit. Based on the known depth and construction of the well and the geology of the subsurface strata, there is very low potential for the well to act as a conduit for contaminants into groundwater or to present a health and safety concern.

\section{WASTE INVENTORY}

The waste inventory in the B Area and the Walk-In Pits includes solid waste (such as wood, metal, paper, glass, and debris) contaminated with depleted uranium chips, metals, and oxides; uranium and thorium saw fines and other shock-sensitive metals; and acids, bases, and organics. These materials will remain in place because attempts to remove these materials would pose potential harm to health and environment.

The Kerr Hollow Quarry debris (a nonhazardous treatment residue) to be dispositioned at the Walk-In Pits consists of shredded carbon and stainless steels; a heterogeneous mixture of mud, rock, shredded plastic bags, and organics such as wood and leaves; small lead pipes; possibly as much as $4 \mathrm{lb}$ of asbestos; uranium and uranium alloys; zirconium metal and metal shavings; crystals of white phosphorus; live ammunition; 9- and 17-mL glass vials containing unknown material; and small sections of pipe or tubing with sealed or crimped ends that may contain unreacted material. This waste was placed in dumpsters and B-25 boxes and overpacked in concrete vaults. The amount of potentially reactive material is relatively small. 
The waste is a treatment residue and is nonhazardous solid waste, based on knowledge of the constituents.

\section{EQUIPMIENT DECONTAMINATION}

Because of the manner in which the B Area and the Walk-In Pits will be closed, equipment decontamination will not be required as part of closure. Wastes were covered with soil after disposal. When a trench was filled, an additional 2- to 3-ft layer of clean soil was added to cover the trench. Equipment should not come into contact with wastes or contaminated material. During construction, recontouring fill will be pushed in front of the equipment over the site such that the equipment will be in contact only with clean soil. If, however, the equipment is contaminated, it will be decontaminated by first scraping off soil remaining on the equipment. Soil residues will be placed beneath the cap. The equipment will then be triple steam cleaned. Personnel will wear protective clothing. Wash and rinse water will be collected. Verification sampling is not proposed for the equipment. However, it will be visually inspected to ensure that no visible residue from the excavation remains. If the equipment is contaminated, radiation monitoring will be performed before the equipment exits the controlled/exclusion area.

\section{DESIGN ELEMENTS OF CLOSURE}

The site (a hilltop and steep side slopes) will be cleared (i.e., trees/brush cut close to the surface in order not to disturb the wastes) and backfilled with clean clay to form a continuous relatively smooth contour (Fig. 3). Because of site topography, the thickness of this clay layer will vary. The Walk-In Pits (a north and south area) contain explosive hazards and will have clay fill placed and compacted in accordance with safety restrictions. A gas- collection vent system will be installed by placing slotted pipes across the hilltop and side slopes. A geotextile fabric and geonet will overlay the site to act as a gas-collection system and to connect to the gas vents. A flexible, synthetic geomembrane liner will be placed on top of the geotextile fabric and geogrid. This geomembrane will be secured by concrete, soil, and rip-rap anchor along its edges and by a mortar-filled fabric envelope over the entire surface. Gas vents will be constructed through the geomembrane layer.

\section{INSTALLATION PROCEDURES}

The construction of the engineered multilayered cap is described below.

\section{COVER PLACEMENT}

\section{Recontouring Fill}

A minimum of $2 \mathrm{ft}$ of soil will be placed over the Walk-In Pits as blast shielding for construction personnel. The explosion potential of the waste materials is very small, and the 2-ft layer is being placed as a precautionary measure. Extensive safety analysis and 


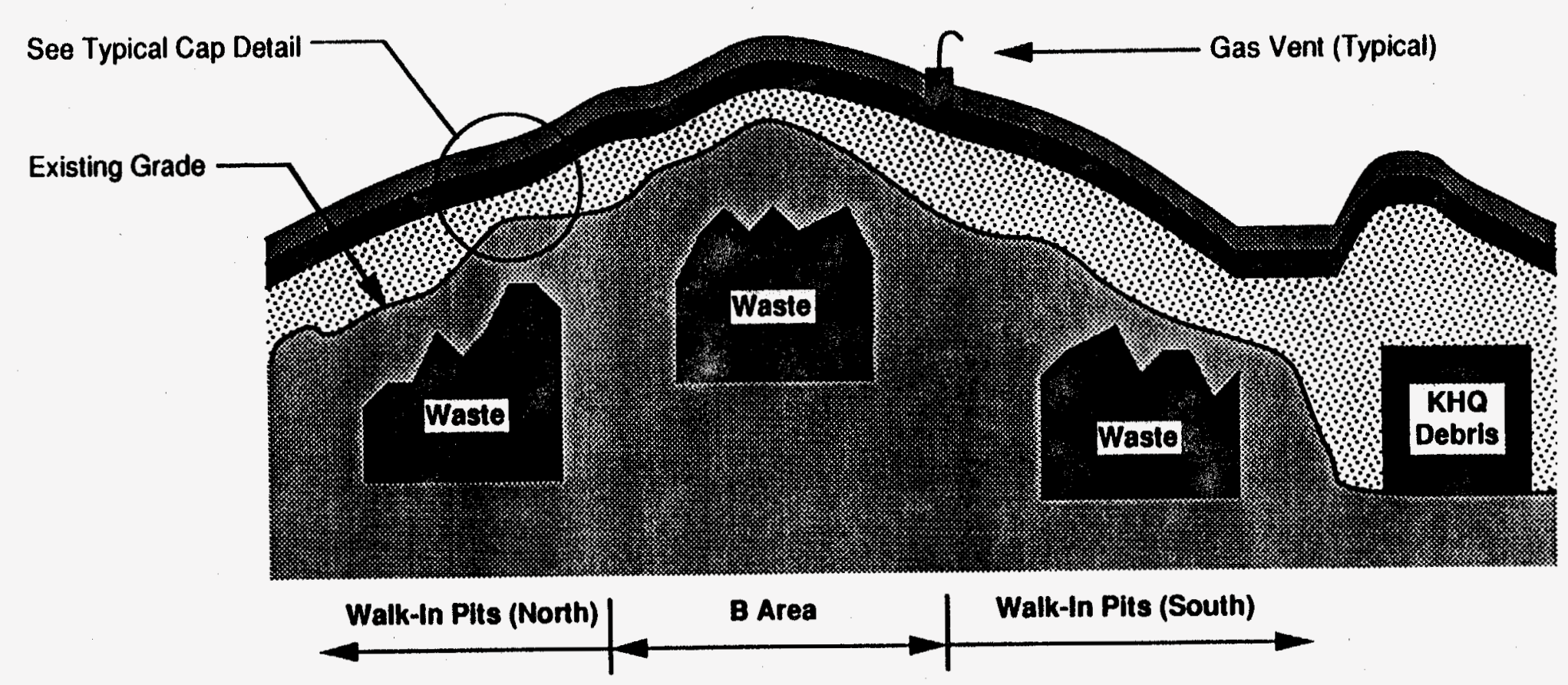

\section{Bear Creak Burial Ground}

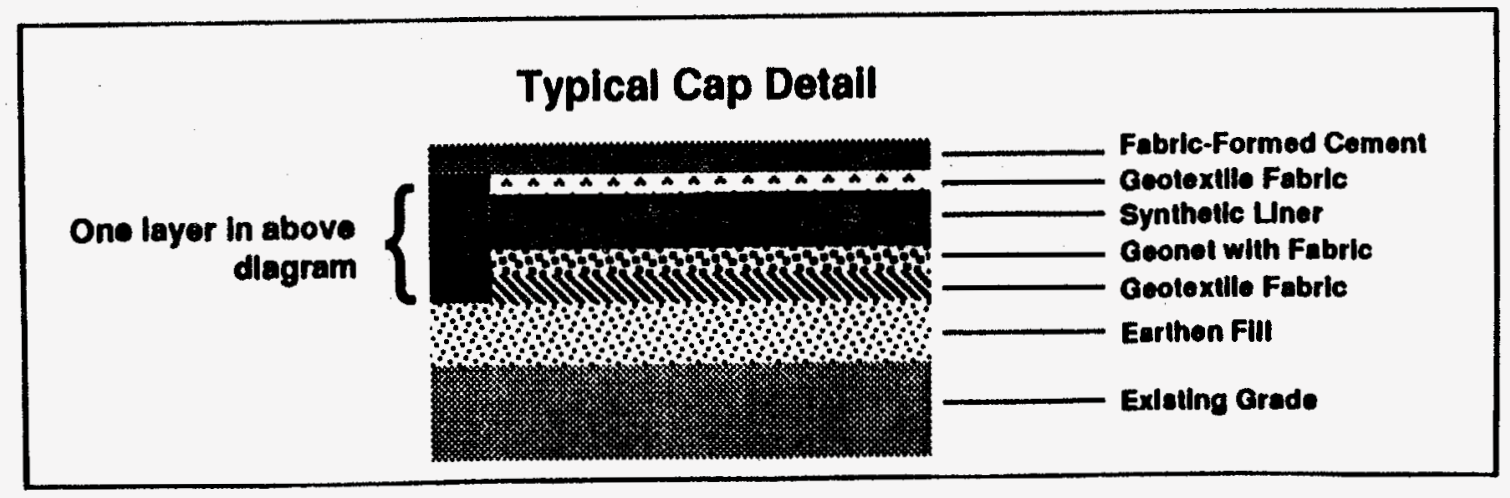

Fig. 3. Cross-section of $B$ Area and Walt-In Pits. 
documentation have been conducted on this project. B Area will also be covered with a minimum of $2 \mathrm{ft}$ of soil.

The site will receive additional soil fill to recontour the uneven terrain. The existing site has areas of very steep slopes, benches, depressions, and other topographic features that would preclude the placement of a flexible geomembrane liner. The site recontouring will produce a smooth, continuous topography without depressions or humps. The fill will be graded smooth prior to placement of the geosynthetic layers.

\section{Geotentile Fabric and Geonet}

A geotextile fabric will be placed over the recontouring fill. The fabric will serve as a cushion to protect the geomembrane above it from puncture. It will serve as a separator to prevent the intrusion of soil into the geonet. The geonet is the gas-collection layer. Any gasses that form in the waste and migrate upward through the cover soil would collect under the geomembrane liner if a gas-venting layer was not provided. The geonet will allow gasses to migrate to a header that is connected to a series of vents. The geotextile and geonet will also serve as a pathway for condensate to migrate to the bottom of the hill.

\section{Geomembrane}

A flexible geomembrane liner will be placed over the geonet to prevent water from infiltrating into the waste. The geomembrane chosen for this cap is one of reinforced polypropylene.

\section{Cover System}

A "fabriform" revetment mat will be placed over the geomembrane. It will provide protection for the geomembrane from wind damage, ultraviolet light (which degrades plastic), and animals (which may perforate the geomembrane with their hooves or burrows). The revetment mat consists of a double-layer fabric into which a highly fluid sand/cement mortar is pumped. The mortar will harden into a concrete layer -4 in. thick Reinforcing tendons will run in each direction within the mat. This type of revetment system is used extensively along shorelines to prevent erosion. In this application it will provide excellent protection for the geomembrane.

Storm-water runoff will be directed to ditches along the perimeter of the site and at the foot of the hill. The fabriform cover will be placed in the ditches to serve as a paved channel for runoff. This will contain storm water, dissipate energy, and prevent erosion.

\section{DRANAGE AND EROSION}

The fabriform cover and the geomembrane are intended to prevent infiltration of rainfall and to control the flow of storm water across the site. Storm runoff will sheet flow over the fabriform cover to swales outside the waste perimeter. The swales will be lined with fabriform and will be continuous with the cap cover. Where the drainage swales exit the site, energy dissipators will be provided to control erosion. 


\section{ADDITIONAL CLOSURE ACTIVTTIES}

\section{CONSTRUCTION QUALTYY ASSURANCE}

The landfill shall be designed, constructed, and operated to protect human health and the environment. To ensure that the completed landfill meets or exceeds all projected design criteria, plans, and specifications, a construction quality assurance (CQA) program is necessary.

1. The owner/operator shall prepare a written CQA plan to be used during construction of the cap. The plan will be used in monitoring and documenting the quality of the materials used and the conditions and manner of their placement. The plan mer developed, administered, and documented by a registered professional civit of geotechnical engineer with experience in landfill construction and construction the. inspections. In addition, the CQA plan will be provided during site inspection to any officer, employee, or representative of the Division who is duly designated by the Commissioner of the Tennessee Department of Environment and Conservation (TDEC). Although the specific content of the CQA plan will depend on site-specific factors, the following specific components will be included, at a minimum:

- areas of responsibility and lines of authority in executing the CQA plan;

- qualifications of CQA personnel;

- frequency and scale of such observations and tests; and

- documentation of CQA. This will include daily record keeping (observation and test data sheets, problem reporting and corrective measures data sheets); design engineer acceptance reports (for errors, inconsistencies, and other problems); and final documentation. After completion of construction, a final documentation report(s) will be prepared. This report(s) will include summaries of all construction activities, observations, test data sheets, deviations from design and material specifications, and as-built drawings.

2. The documentation for the CQA program will be kept in the facility operating record.

\section{CONSTRUCTION DRAWINGS}

Construction drawings shall be prepared and submitted to the Commissioner before. construction is initiated. These drawings shall depict the proposed final contours after cap placement; cross-sections showing each layer of the cap, including slopes; and run-on/runoff control structures, including calculations supporting the design. 


\section{TRAFFIC CONTROL}

When cap construction is completed, the access roads in the vicinity of this site will be routed such that no road crosses any portion of the Walk-In Pits and B Area. Traffic will be restricted from leaving the roadways by an existing 6-ft-high chain-link and gates fence between the roadways and the burial ground disposal areas.

\section{CLOSURE SCHEDULE}

A closure schedule for BCBG B Area and the Walk-In Pits is presented in Table 1.

Table 1. Schedule for closure of Bear Creek Burial Grounds

B Area and Walk-In Pits

\begin{tabular}{lc}
\hline \multicolumn{1}{c}{ Activity } & Dates/durations \\
\hline Closure Plan submitted (D3) & $04 / 19 / 93$ \\
Closure Plan approved & TBD $^{\mathbf{a}}$ \\
CFC drawings submitted & 30 calendar days from approval \\
Start construction & 30 calendar days from approval \\
Complete construction & 365 calendar days from approval \\
Submit closure certification to TDEC & 60 calendar days from \\
& construction completion \\
\hline
\end{tabular}

"To be determined

${ }^{b}$ Certified for construction.

\section{NOTICE TO LOCAL LAND AUTHORITY}

Within 90 days after final closure is completed, a survey plat indicating the location and dimensions of landfill pits, trenches, and disposal areas with respect to permanently surveyed benchmarks will be submitted to the local land authority and to the Commissioner of TDEC. The plat will be prepared and certified by a professional land surveyor. The survey plat will contain the following prominently displayed note or a similarly worded note to comply with Tennessee Rule 1200-1-11-.05(7)(i):

The owner or operator of the property containing the Bear Creek Burial Grounds as shown on this plat is obligated to restrict disturbance of the site in accordance with Rules Governing Hazardous Waste Management in Tennessee. Postclosure use of the property on or in which hazardous wastes remain must never be allowed to disturb the integrity of the final cover, liner(s), or any other components of any containment system or the function of the facility's monitoring systems unless the owner or operator receives approval from the Commissioner of the Tennessee Department of Environment and Conservation under the previously referenced rules. 
To comply with Tennessee Rule 1200-1-11-.05(7)(i), a record and identification of the type, location, and quantity of hazardous wastes disposed of within the pits, trenches, and disposal areas of the facility shall be submitted to the Commissioner and local land authority. The record and identification of the type, location, and quantity of waste shall be based upon best available knowledge and records.

\section{NOTICE IN DEED TO PROPERTY}

The note presented in the previous section, Notice to Local Land Authority, or a similarly worded note complying with Tennessee Rule 1200-1-11-.05(7)(j) will be recorded on the facility property deed or on some instrument normally examined during title search.

\section{CLOSURE CERTIFICATION}

The Department of Energy (DOE) will submit closure certifications from both DOE and an independent registered professional engineer that closure has been completed in accordance with the approved closure plan. The certifications shall be submitted to the Commissioner within 60 days after closure is completed.

\section{OTHER ACTIVITIES}

Further investigation or remediation will not be included in RCRA closure activities. Any future monitoring (e.g., groundwater), assessments, or remediation will be conducted as part of the ongoing Comprehensive Environmental Response, Compensation, and Liability Act activities at the Y-12 Plant. These activities will be conducted in compliance with the Federal Facility Agreement.

\section{INSPECTION AND MAINTENANCE PLAN}

\section{NTRODUCTION}

This Inspection and Maintenance Plan describes potential problems that could affect the performance of the cap, inspection criteria, inspection frequency, and other monitoring and maintenance requirements.

\section{POTENTIAL POSTCLOSURE PROBLEMS}

\section{Settlement/Subsidence}

For the purposes of this plan, settlement is defined as elevation change as a result of consolidation of near surface soils under applied load. Subsidence is the loss of near surface materials into existing void space. Uniform settlement of materials under a cap is generally not a problem, because the cap moves as a unit and is not distressed. If severe, differential settlement or subsidence could result in distress to the geomembrane layer of the cap. On the 
BCBG B Area and Walk-In Pits cap, it is considered quite unlikely that differential settlement or subsidence would distress the cap for the following reasons:

1. The type of construction proposed is quite tolerant of settlement. Large uniform settlements are of no consequence to the proposed geomembrane cap. If moderate differential settlement (less than 6 in.) does occur, the geomembrane and anchorage system can conform to the terrain with no loss of integrity.

2. The chance of differential settlement or subsidence is very small because the probability of large voids or soft areas on the site is low. The waste and some cover soil have been in place for years. Many voids have been filled, and the soil has consolidated over time. The additional cover soil will be placed in such a way that new voids will not be created.

3. If voids that could cause large differential settlements exist, they would probably show up when the initial lifts of soil are placed over the site and the heavy equipment compacts it. The voids will be filled at that time and would present no long-term problems to the cap.

4. Once the cap is in place and rain water infiltration is controlled, the primary motive force for displacement of soils on site is eliminated. The probability of a subsidence incident after the cap is in place should diminish even further.

\section{Geomembrane Distress}

The primary forces that degrade a geomembrane are ultraviolet light, animal/human intrusion, and wind uplift. The design includes a grout-filled revetment mat layer which mitigates the effects of all of these degrading forces. The mat shields the geomembrane liner from ultraviolet light (sunlight), protects it from hoofed animals and inadvertent human intrusion, and provides an anchorage system to prevent wind uplift.

\section{Uncontrolled Storm Runoff}

The site currently has locations where storm runoff is concentrating and causing erosion. When cap construction is complete, the entire area will be covered such that there will no longer be any exposed soil. The design addresses runoff by providing paved ditches a required to convey storm water off the site. Energy dissipators are included in the design to slow down the flow. Because of its textured surface, the revetment mat over the geomembrane also limits the velocity of storm runoff.

\section{POSTCLOSURE INSPECTION}

Although the design has incorporated features that address most of the potential postconstruction problems, a postclosure inspection program will be implemented. The postclosure inspection program will focus on two areas of concern: settlement/subsidence monitoring and growth of undesirable vegetation. Inspection will be performed by a combination of visual, analytical, and measurement techniques. 
Vixual Inspection

Periodic visual inspections of the BCBG B Area and Walk-In Pits cap will be made. Following the completion of construction activities, inspections will be performed monthly for the first 6 months and then quarterly thereafter. The following cap components will be included in the periodic visual inspection:

1. The perimeter of the cap and the perimeter drainage ditches will be inspected for any damage, especially that due to animals burrowing under the edge of the cap.

2. The inspector will walk the cap (except for access-limited areas) and visually inspect for damage or degradation. The inspector will evaluate the general condition of the protective cover mat. Special emphasis will be given to visually inspecting for signs of differential settlement and subsidence and the presence of unwanted vegetation.

3. Areas of the site in which access restrictions apply because of safety concerns will be visually inspected from the perimeter of those areas. The longest distance from the edge of any limited access area to the center of that area is $-100 \mathrm{ft}$.

Fig. 4).

Inspections will be documented by completion of a Postclosure Inspection Checklist (see

\section{Subsidence Monitoring}

Site topographic surveys coupled with photogrammetric methods will be employed to monitor the site for subsidence. A baseline survey of the site will be performed at the completion of cap construction. Monitoring surveys of cap elevations will be performed annually. The accessible areas will have benchmarks that will be surveyed by conventional methods. The access-limited areas will be surveyed remotely or mapped by aerial or landbased photogrammetric methods. The results of the annual monitoring survey will be a topographical map that can be compared with the baseline to determine if subsidence has occurred and the extent of subsidence. If an area of subsidence is found, and if the cover is 6 in. lower than the baseline topographic elevation at that location, a formal investigation of the subsidence incident will be initiated.

\section{Umwanted Vegetation}

The presence of limited vegetation on the cap has no adverse effect on cap performance or cap integrity. However, unlimited growth of vegetation over a long period of time could pose a problem for the cap. The scenario under which vegetation would damage the cap is as follows. If trees were allowed to grow on the cap, the roots could not penetrate the geomembrane. Therefore, they would grow around the revetment mat and be very shallow. If trees grew large enough, high winds could upend the trees, damaging the revetment mat and possibly the liner.

To control the growth of unwanted vegetation, the area will be treated with a suitable herbicide such as Round-up. The herbicide would be sprayed over the site on an as-needed basis. The decision to spray would be based on visual inspections. The criterion for herbicide application would be to make application when vegetation growth exceeds a height of 6 in. above the revetment mat. 
Inspector's Name and Title

Date of Inspection

TIme of Inspection

Date Next Topo Survey is Due

Inspector's Signature

Supervisor's Signature

\begin{tabular}{|c|c|c|c|c|c|}
\hline $\begin{array}{l}\text { INSPECTION } \\
\text { TEMII }\end{array}$ & $\begin{array}{l}\text { TYPE OF } \\
\text { PROBLEM }\end{array}$ & $\begin{array}{l}\text { ACCEPT/ } \\
\text { REJECT }\end{array}$ & OQsenvations & $\begin{array}{c}\text { CORAECTIVE } \\
\text { ACTION }\end{array}$ & 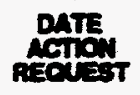 \\
\hline $\begin{array}{l}\text { Erosion of Cap } \\
\text { Perimeter }\end{array}$ & $\begin{array}{l}\text { Gullies, rills, bare } \\
\text { soil around } \\
\text { perimeter or in } \\
\text { drainage ditches }\end{array}$ & & & $\begin{array}{l}\text { Restore areas to } \\
\text { design grade and re- } \\
\text { seed }\end{array}$ & \\
\hline $\begin{array}{l}\text { Protective } \\
\text { Cover Mat }\end{array}$ & $\begin{array}{l}\text { Damage or } \\
\text { degradation, } \\
\text { vegetation over } 6 \\
\text { inches } \\
\end{array}$ & & & $\begin{array}{l}\text { Repair damaged or } \\
\text { degraded mat } \\
\text { sections, treat with } \\
\text { herbicide }\end{array}$ & \\
\hline $\begin{array}{l}\text { Subsidence or } \\
\text { Settlement }\end{array}$ & $\begin{array}{l}\text { Any areas where } \\
\text { visual observations } \\
\text { detect subsidence } \\
\text { or settlement of the } \\
\text { cover }\end{array}$ & & & $\begin{array}{l}\text { Report condition to } \\
\text { management for } \\
\text { investigation }\end{array}$ & \\
\hline $\begin{array}{l}\text { Run-on and } \\
\text { Run-off Control } \\
\text { System }\end{array}$ & $\begin{array}{l}\text { Ponding, blockage, } \\
\text { erosion }\end{array}$ & & & $\begin{array}{l}\text { Regrade and } \\
\text { seed/rip-rap low or } \\
\text { eroded areas, } \\
\text { remove blockage }\end{array}$ & \\
\hline Rodent Damage & $\begin{array}{l}\text { Burrowing and other } \\
\text { damage from } \\
\text { rodents }\end{array}$ & & & $\begin{array}{l}\text { Repair damage and } \\
\text { implement animal } \\
\text { control measures }\end{array}$ & \\
\hline Bench Marks & $\begin{array}{l}\text { Damaged, } \\
\text { disiocated, or } \\
\text { missing survey } \\
\text { benchmarks } \\
\end{array}$ & & & $\begin{array}{l}\text { Replace or repair } \\
\text { monuments, } \\
\text { resurvey }\end{array}$ & \\
\hline Signage & $\begin{array}{l}\text { Damaged, } \\
\text { deteriorated, or } \\
\text { missing signs }\end{array}$ & & & $\begin{array}{l}\text { Repair or replace } \\
\text { signs }\end{array}$ & \\
\hline $\begin{array}{l}\text { Unauthorized } \\
\text { Materials }\end{array}$ & $\begin{array}{l}\text { Unauthorized } \\
\text { materials placed in } \\
\text { area }\end{array}$ & & & $\begin{array}{l}\text { Obtain management } \\
\text { instructions for } \\
\text { removal of materials }\end{array}$ & \\
\hline
\end{tabular}

(Photograph and/or sketch deteriorated areas)

Fig. 4. Eample Postclosure Inspection Checklist. 


\section{DISTRIBUTION}

1. W. D. Barton III

2. E. T. Collins

3. M. F. P. DeLozier

4. J. D. Gass

5. C. D. Goins

6. J. T. Grumski

7. P. J. Halsey

8. J. E. Heiskell

8. P. H. Hight

9. C. C. Hill

10. R. M. Hill

11. I. W. Jeter

12. W. D. Jones

13. A. K Lee

14. L. W. Long

15. W. E. Manrod

16. J. Q. Miller

17. M. Mitchell

18. H. C. Newsom/D. C. White

19-21. D. M. Matteo

22. L. S. McAdams
23. L. W. McMahon

24-25. P. T. Owen

26. T. P. A. Perry

27. J. E. Powell

28. G. E. Rymer

29. J. K Siberell

30. C. M. Smith

31. J. E. Stone

32. C. C. Travis

33. R. R. Turner

34. J. H. Vanderlan

35. R. W. Weigel

36. R. K. White

37. A. K. Zava

38. Central Research Library

39-43. ER Document Management Center

44. Y-12 ER Document Center

45. $Y-12$ Central Files

46. H. W. Hibbits, DOE Oak Ridge Field Office, P.O. Box 2001, Oak Ridge, TN 37831-8541

47-48. R. L Nace, Branch Chief, Nonenrichment Facilities, Oak Ridge Program Division, Office of Eastern Area Programs, Office of Environmental Restoration, EM-423, Trevion 2, U.S. Department of Energy, Washington, DC 20585

49-55. S. L. Lankford, DOE Oak Ridge Field Office, P.O. Box 2001, Oak Ridge, TN 37831-8541

56. R. D. Oglesby, DOE Oak Ridge Field Office, P.O. Box 2001, Oak Ridge, TN 37831-8541

57. J. Powell, DOE Oak Ridge Field Office, P.O. Box 2001, Oak Ridge, TN 37831-8541

58. R. J. Spence, DOE Oak Ridge Field Office, P.O. Box 2001, Oak Ridge, TN 37831-8541

59. D. W. Swindle, Radian Corporation, $120 \mathrm{~S}$. Jefferson Circle, Oak Ridge, TN 37830

60-61. H. M. Thron, Chief, Enrichment Facilities, Oak Ridge Program Division, Office of Eastern Area Programs, Office of Environmental Restoration, EM-423, Trevion 2, U.S. Department of Energy, Washington, DC 20585

62-63. Office of Scientific and Technical Information, P.O. Box 62, Oak Ridge, TN 37831 
A.2 Post-Closure Plan

3 


\section{BEAR CREEK HYDROGEOLOGIC REGIME \\ WALK-IN PITS \\ POST-CLOSURE PLAN}

1.0 Post-Closure Care and Use of Property

Ref: $1200-1-11-.05(7)(a)$

This information is detailed in the following sections.

\subsection{Length of Post-Closure Care Period \\ Ref: $1200-1-11-.05(7)(a)$}

Post-closure care of the WIPs will continue for 30 years after date of final closure.

\subsection{Increasing/Decreasing Length of Post-Closure Care Period \\ Ref: $1200-1-11-.05(7)(a)$}

All activities described in this plan will continue throughout the post-closure care period unless a demonstration is made to and accepted by Tennessee Department of Environment and Conservation (TDEC) that a certain post-closure activity is no longer necessary to provide sufficient protection of human health and the environment.

\subsection{Security Requirements \\ Ref: $1200-1-11-.05(7)(a)$}

Security will be maintained at the WIPs for 30 years after closure is completed. If it is determined that security around the facility can be terminated or reduced, a petition with explanation and justification will be submitted to the Commissioner requesting reduction or elimination of security requirements. Access to the site is restricted to authorized personnel only. Large signs prohibiting nonbusiness traffic are posted upon entry to the Y-12 Plant area. Access roads to the site have lockable gates. The area is routinely patrolled by security personnel. 


\subsection{Property Use Restrictions \\ Ref: $1200-1-11-.05(7)(a)$}

Post-closure use of the property, including the capped portion of the facility, will be restricted to prevent disturbance of the final cover, of containment system components, and the functioning of the monitoring system.

\subsection{Submittal of Post-Closure Plan Ref: $1200-1-11-.05(7)(a)$}

This Post-Closure Plan is being submitted as part of the Addendum to the Post-Closure Permit Application for the Bear Creek Hydrogeologic Regime at the Y-12 Plant: Walk-In Pits.

\subsection{Availability of Post-Closure Plan Ref: $1200-1-11-.05(7)(a)$}

The name, address, and phone number of the office to contact about the WIPs during the post-closure period are listed below. An updated post-closure plan for the facility will be maintained in this office during the post-closure period.

Department of Energy

Environmental Restoration Division

P.O. Box 2001

Oak Ridge, Tennessee 37831-8012

(615) 576-0715

\subsection{Content of Post-Closure Plan}

Ref: $1200-1-11-.05(7)(a)$

This information is detailed in the following sections. 


\subsection{Monitoring Activities Described \\ Ref: $1200-1-11-.05(7)(a)$}

Groundwater monitoring activities to be performed after issuance of a post-closure permit for the WIPs are presented in Section B.5 of the PCPA for the BCBG (Geraghty \& Miller, Inc. 1994).

\subsection{Maintenance Activities Described \\ Ref: $1200-1-11-.05(7)(a)$}

Post-closure performance of the facility is strongly dependent on adequate inspection and maintenance of the cover. All components of the WIPs will be inspected quarterly throughout the post-closure care period. Comprehensive monitoring well inspections will be performed annually.

The items to be inspected and any corrective actions needed are outlined in Table 1. The inspector will check the general condition of the cap looking for areas of settlement or subsidence and for undesirable vegetation. The inspector will note the presence of any ponded water on the cap or evidence of damage.

All detection monitoring wells will be inspected by sounding the well. Rehabilitation or redevelopment will be conducted on those wells in which the sounding results indicate a well depth change of 20 percent or greater of the total screen length or of the open interval. In addition, as a part of the inspection program, all monitor wells will be inspected to check for proper identification, damage, and to make sure that the protective caps are locked. The benchmarks at the boundaries of the disposal units will be inspected to determine if they have been damaged.

Run-on and run-off drainage control structures will be inspected as a part of the general facility inspection. Channels will be inspected for signs of settlement, ponding, blockage, vegetation, and other visible factors which could affect their performance. 
Table 1. Inspection and Maintenance Plan for the Walk-In Pits Energy Systems, Inc. Y-12 Plant Oak Ridge, Tennessee

Inspection

Corrective Action

\section{Condition of Cover}

- Check for erosion at cap perimeter

- Check for damage, degradation, or unwanted vegetation.

\section{Cover Settlement}

- Check for subsidence, especially any differential settlement.

- Check for cracks, potholes, etc. in cover.

\section{Monitoring Wells}

- Check for damage, make sure protective caps are locked.

\section{Run-On and Run-Off Drainage Control System}

- Check for signs of settlement, ponding, blockage, etc.

\section{Benchmarks}

- Check for damage or missing survey benchmarks.

- Check for damage/burrows.

\section{Rodent Control}

Restore area to design grade and reseed Repair damaged cover, treat with herbicides.

Report condition.

If samples cannot be obtained, seal damaged well and construct replacement well at same location.

Repair settlement, regrade, and remove blockages.

Replace or repair. Resurvey.

Repair damage; implement animal control measures.

\section{Signage}

- Check for damaged or missing signs.
Repair or replace signs. 
Following each inspection, the inspector will complete a Post-Closure Inspection Checklist for the site. Figures 1 and 2 are examples of inspection checklists to be completed.

The primary maintenance activity at the WIPs will be the maintenance of the cover at the site. Also, routine maintenance of the drainage system will include regular removal of visible blockages and repair of unstable areas. Any additional channel maintenance requirements will be promptly addressed as they are noted.

Site maintenance will include repair of any damages observed during the site inspection. If monitoring wells are damaged such that representative samples of groundwater cannot be obtained, the wells will be plugged and replaced upon receiving written concurrence from the Commissioner. The damaged well will be plugged and abandoned in accordance with the most current approved version of the procedure described in Appendix $\mathrm{C}$ of this addendum to the PCPA.

\subsection{Post-Closure Contact Identified \\ Ref: $1200-1-11-.05(7)(a)$}

The name, address, and telephone number of the offices to contact regarding the WIPs during post-closure care period is listed below. An updated post-closure plan for the facility will be maintained in this office during the post-closure period.

Department of Energy

Environmental Restoration Division

P.O. Box 2001

Oak Ridge, TN 37831-8012

(615) 576-0715

\subsection{Amendment of Post-Closure Plans \\ Ref: $1200-1-11-.05(7)(a)$}

An amended post-closure plan will be submitted to the Commissioner whenever:

(1) changes in operating plans or facility design affect the post-closure plan; or (2) events 
Inspector: Name

Inspection: Date

Title

Time

Date Next Topo Survey is Due:

Inspector's Signature

Supervisor's Signature

\begin{tabular}{|c|c|c|c|c|c|}
\hline $\begin{array}{l}\text { INSPECTION } \\
\text { ITEM }\end{array}$ & $\begin{array}{l}\text { TYPE OF } \\
\text { PROBLEM }\end{array}$ & $\begin{array}{l}\text { ACCEPTI } \\
\text { REJECT }\end{array}$ & OBSERVATIONS & $\begin{array}{l}\text { CORAECTIVE } \\
\text { ACTION }\end{array}$ & $\begin{array}{c}\text { DATE } \\
\text { ACTION } \\
\text { REOUEST }\end{array}$ \\
\hline $\begin{array}{c}\text { Erosion of Cap } \\
\text { Perimeter }\end{array}$ & $\begin{array}{l}\text { Gullies, rills, bare } \\
\text { soil around } \\
\text { perimeter or in } \\
\text { drainage ditches }\end{array}$ & & & $\begin{array}{c}\text { Restore areas to } \\
\text { design grade and } \\
\text { reseed }\end{array}$ & \\
\hline $\begin{array}{l}\text { Protective } \\
\text { Cover Mat }\end{array}$ & $\begin{array}{c}\text { Damage or } \\
\text { degradation, } \\
\text { vegetation over six } \\
\text { inches }\end{array}$ & & & $\begin{array}{c}\text { Repair damaged or } \\
\text { degraded mat } \\
\text { sections, treat with } \\
\text { herbicides }\end{array}$ & \\
\hline $\begin{array}{c}\text { Subsidence or } \\
\text { Settlement }\end{array}$ & $\begin{array}{c}\text { Any areas where } \\
\text { visual coservations } \\
\text { detect subsidence } \\
\text { or settlement of the } \\
\text { cover }\end{array}$ & & & $\begin{array}{c}\text { Report condition fo } \\
\text { management for } \\
\text { imvestigation }\end{array}$ & \\
\hline $\begin{array}{l}\text { Run-on and } \\
\text { Run-off Control } \\
\text { System }\end{array}$ & $\begin{array}{c}\text { Ponding, blockage, } \\
\text { erosion }\end{array}$ & & & $\begin{array}{c}\text { Regrade and } \\
\text { seedlip-rap low or } \\
\text { eroded areas, } \\
\text { remove blockage }\end{array}$ & \\
\hline $\begin{array}{l}\text { Rodent } \\
\text { Damage }\end{array}$ & $\begin{array}{c}\text { Burrowing and } \\
\text { other damage trom } \\
\text { rodents }\end{array}$ & & & $\begin{array}{c}\text { Repair damage } \\
\text { and implement } \\
\text { animal control } \\
\text { measures }\end{array}$ & \\
\hline Bench Marks & $\begin{array}{l}\text { Damaged, } \\
\text { cisbcated, or } \\
\text { missing survey } \\
\text { benchmarks }\end{array}$ & & & $\begin{array}{c}\text { Reptace or repair } \\
\text { monuments. } \\
\text { resurvey }\end{array}$ & \\
\hline Signage & $\begin{array}{l}\text { Damaged, } \\
\text { deteriorated, or } \\
\text { missing signs }\end{array}$ & & & $\begin{array}{c}\text { Repair or replace } \\
\text { signs }\end{array}$ & \\
\hline $\begin{array}{l}\text { Unauthorized } \\
\text { Materials }\end{array}$ & $\begin{array}{c}\text { Unauthorized } \\
\text { materials placed in } \\
\text { area }\end{array}$ & & & $\begin{array}{l}\text { Obtain } \\
\text { management } \\
\text { instructions for } \\
\text { removal of } \\
\text { materials } \\
\end{array}$ & \\
\hline
\end{tabular}

(Pholograph and/or sketch deteriorated areas)

Example of a Post-Closure Inspection Checklist

Energy Systems, Inc. $\quad$ Y-12 Plant $\quad$ Oak Ridge, Tennessee 


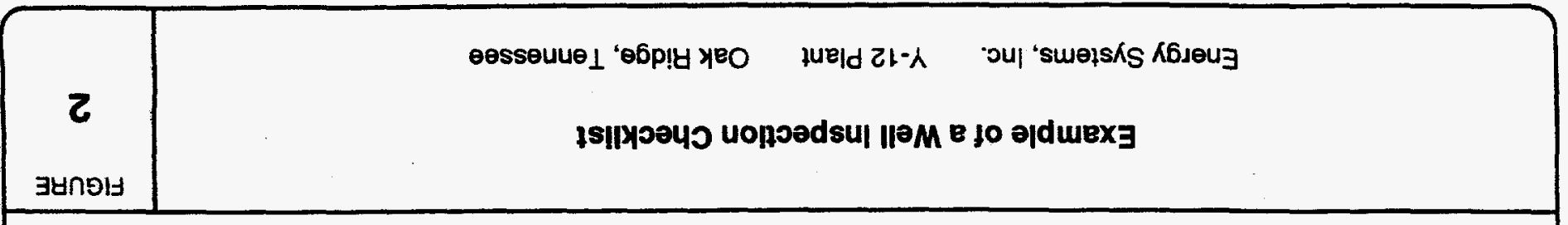

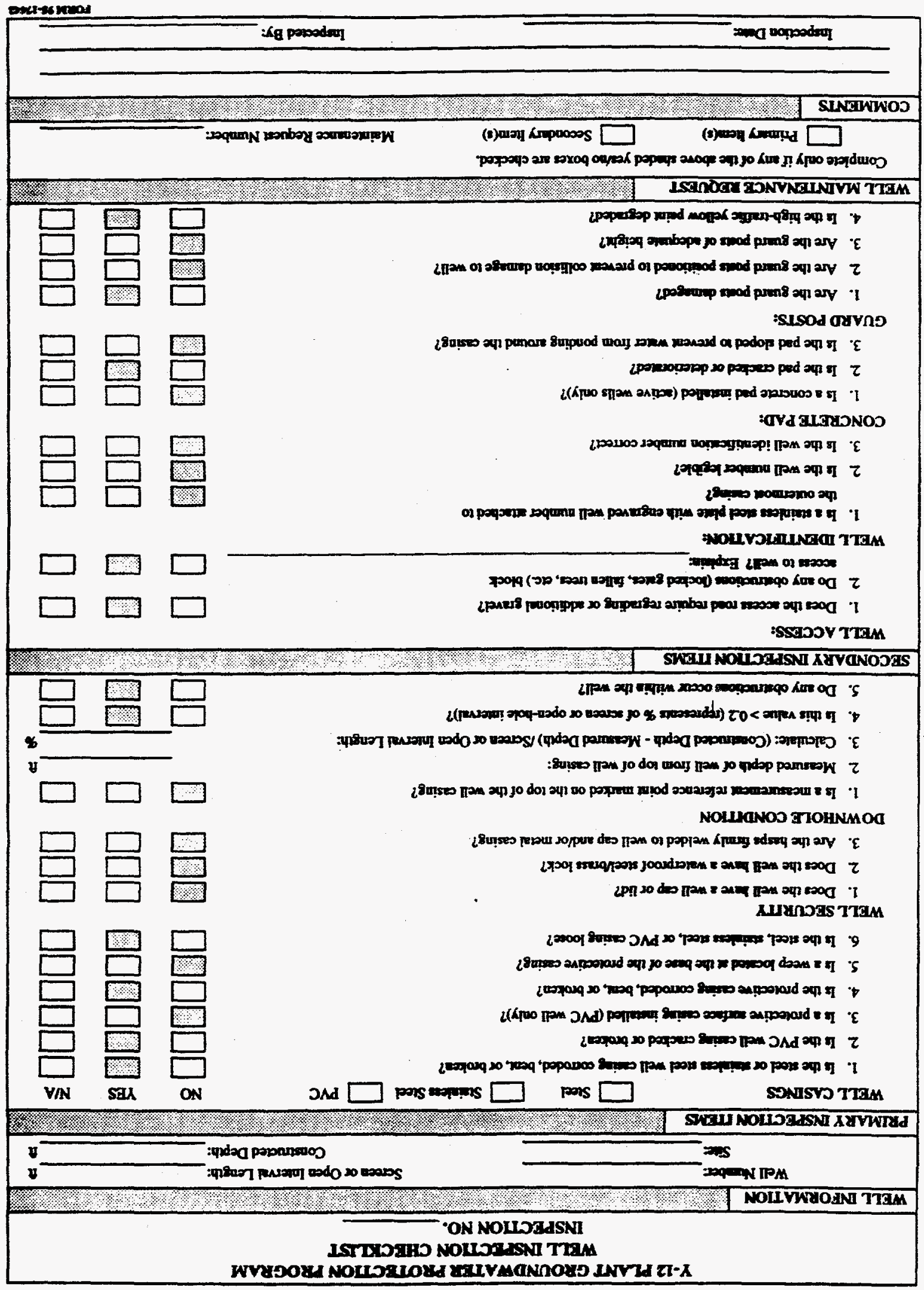


which occur during the final closure affect the post-closure plan. The post-closure plan will be amended at least 60 days prior to the proposed change in facility design or operation, or not later than 60 days after an unexpected event has occurred which has affected the post-closure plan.

\subsection{Post-Closure Notices \\ Ref: $1200-1-11-.05(7)(a)$}

This information is detailed in the following sections.

\subsection{Notice to Local Zoning Authority/Record of Wastes \\ Ref: 1200-1-11-.05(7)(a)}

Following certification of closure, a record and identification of the type, location, and quantity of hazardous wastes disposed of within the WIPs was submitted to the Commissioner and the local land authority. The record and identification of the type, location, and quantity of wastes was based upon best available knowledge presented in the closure-plan (Appendix A.1) and sections A.1 and A.2 of this addendum to the PCPA concerning facility description and maximum waste inventory.

\subsection{Notice in Deed/Survey Plat \\ Ref: $1200-1-11-.05(7)(a)$}

Following certification of closure, a notation on the plant property deed or some instrument normally examined during a title search, was recorded. This notation contained the following or similarly worded note:

"The owner or operator of the property containing the Walk-In Pits as shown on this plat is obligated to restrict disturbance of the site in accordance with Rules Governing Hazardous Waste Management in Tennessee. Post closure use of the property on or in which hazardous wastes remain must never be allowed to disturb the integrity of the final cover, liner(s), or any other components of any containment system, or the function of the facility's monitoring systems unless the owner or operator receives approval from the Commissioner of Tennessee Department of Environment and Conservation under the previously referenced rules." 
A survey plat indicating the locations and dimensions of the land treatment area with respect to permanently surveyed benchmarks was submitted to the local land authority and to the Commissioner of the TDEC.

\subsection{Certification of Notice \\ Ref: $1200-1-11-.05(7)(a)$}

A certification by DOE was submitted to the Commissioner stating that the required notations in the deed have been recorded.

\subsection{Removal of Wastes From a Closed Landfill \\ Ref: $1200-1-11-.05(7)(a)$}

The WIPs have been closed in place, therefore, removal of waste is not planned at this time.

\subsection{Certification of Completion of Post-Closure Care \\ Ref: $1200-1-11-.05(7)(a)$}

DOE will submit, by registered mail, a certification that the post-closure care period for the unit was conducted in accordance with the approved post-closure plan. This certification will be submitted no later than 60 days after completion of the established post-closure care period. It will be signed by the owner/operator and an independent certified registered professional engineer. Documentation supporting the engineer certification will be furnished upon request.

\subsection{Post-Closure Care Cost Estimate \\ Ref: $1200-1-11-.05(8)(a) 1$ and 1200-1-11-.05(8)(e)1}

In accordance with the above references, federal facilities are exempt from providing post-closure care cost estimates. 
8.1 Adjustments to Post-Closure Care Cost Estimates

Ref: $1200-1-11-.05(8)(a) 1$ and 1200-1-11-.05(8)(e)1

In accordance with the above references, federal facilities are exempt from the requirements concerning the submittal of cost estimates.

8.2. Revisions to Post-Closure Care Cost Estimates

Ref: $1200-1-11-05(8)(\mathrm{a}) 1$ and 1200-1-11-.05(8)(e)1

In accordance with the above references, federal facilities are exempt from the requirements concerning the submittal of cost estimates.

9.0 Financial Assurance for Post-Closure Care

Ref: $1200-1-11-.05(8)(\mathrm{a}) 1$ and $1200-1-11-.05(8)(\mathrm{f}) 1$

In accordance with the above references, federal facilities are exempt from the requirements pertaining to financial assurance.

10 


\section{A.3 Closure Certification Letter}


TATE OF TENNESSEE

DEPARTMENT OF ENVIRONMENT AND CONSERVATION

Division of Solid Waste Management

Fifth Floor, L \& C Tower

401 Church Street

Nashville, Tennessee 37243-1535

February 22, 1995

Certified Mail

No. P 198160757

Return Receipt Requested

Mr. Robert C. Sleeman

Environmental Restoration Division

U.S. Department of Energy

Oak Ridge Operations Office

Post Office Box 2001

Oak Ridge, Tennessee 37831-8541

Re: Closure Certification

Bear Creek Burial Grounds B Area and Walk-In Pits

Y-12 Plant

EPA I.D. No.: TN3 890090001

Dear Mr. Sleeman:

This letter is to inform you that the Tennessee Department of Environment and Conservation's Division of Solid Waste Management has completed its review of the Owner/Operator/Co-Operator and Independent Registered Professional Engineer Closure Certifications submitted for the above referenced site.

The Department concurs that closure has been performed in accordance with the approved closure plan and in compliance with the closure performance standards of 40 CFR 265.111 as incorporated by reference at Rule 1200-1-11$.05(7)(a)$.

Please recognize that closure of these units means that you are no longer authorized to operate these units under interim status. If, in the future, you wish to conduct operations that require a permit, you must first apply for and obtain that permit from this Department. 
Mr. Robert C. Sleeman

February 22, 1995

Page 2

If you have any questions, please contact Mr. Edward Cox of my staff at (615) 532-0827.

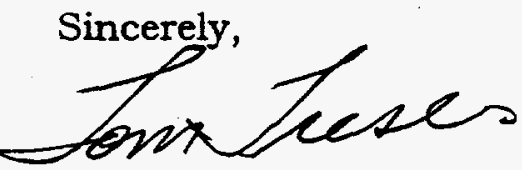

Tom Tiesler, Director

Division of Solid Waste Management

$\mathrm{JTT} / \mathrm{mec}$

cc: $\quad$ Ms. Jacqueline Okoreeh-Baah, Chief, Combustion Unit

Mr. Wayne Gregory, Chief, HW Permitting Unit

Mr. Bill Krispin, Chief, RCRA Land Unit

Mr. Earl Leming, Director, DOE Oversight Division

Mr. G. Alan Farmer, EPA, Region IV

Ms. Sherry Lankford, U. S. DOE

Mr. Tom Perry, Martin Marietta Energy Systems, Inc.

Mr. Mark Burris, MMES 


\section{APPENDIX B}

WELL-CONSTRUCTION DIAGRAMS FOR THE WELLS

IN THE BEAR CREEK HYDROGEOLOGIC REGIME 
Refer to the PCPA for the BCBG (Geraghty \& Miller, Inc. 1994) 
APPENDIX C

APPLICABLE STANDARD PRACTICE PROCEDURES FOR THE GROUNDWATER PROTECTION PROGRAM

C. 1 Well Plugging and Abandonment Procedure C.2 Well Inspection Procedure

C.3 Well Depth Measurement Procedure 
C.1 Well Plugging and Abandonment Procedure 
Oak Ridge Y-12 Plant

Groundwater Protection Program

Standard Practice Procedure

Well Plugging and Abandonment Procedure

Rev. I., October 1994

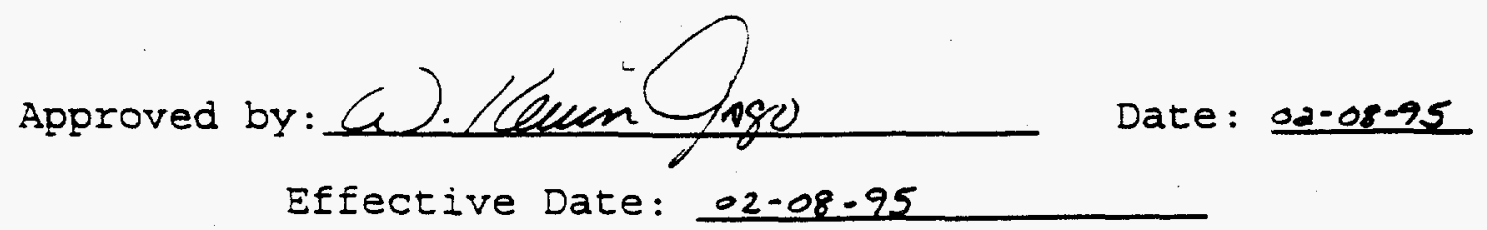

Record of Changes

\begin{tabular}{|c|c|c|c|c|c|c|c|}
\hline $\begin{array}{c}\text { Change } \\
\text { Vo. }\end{array}$ & $\begin{array}{c}\text { Affected } \\
\text { Pages }\end{array}$ & $\begin{array}{c}\text { Approved } \\
\text { Date }\end{array}$ & Expiration Date & $\begin{array}{c}\text { Change } \\
\text { No. }\end{array}$ & $\begin{array}{c}\text { Affected } \\
\text { Pages }\end{array}$ & $\begin{array}{c}\text { Approved } \\
\text { Date }\end{array}$ & $\begin{array}{c}\text { Expiration } \\
\text { Date }\end{array}$ \\
\hline \hline & & & & & & & \\
\hline & & & & & & & \\
\hline & & & & & & & \\
\hline
\end{tabular}

Next 3-year review required no later than: October 1997 


\section{Y-I2 PLANT GROUNDWATER PROTECTION PROGRAM}

TITLE: Weil Plugging and Abandonment Procedure
G-003

Rev. 1.

October 1994

Page 2 of 18

CONIENTS

Page

1.0 PURPOSE . . . . . . . . . . . . . . . . . . . . . . . . 4 4

2.0 APPLICABILITY . . . . . . . . . . . . . . . . . . . . 4

3.0 DEFINITIONS . . . . . . . . . . . . . . . . . . . . . . 4 4

4.0 REFERENCES . . . . . . . . . . . . . . . . . . . . 5

5.0 PRECAUTIONS AND LIMITATIONS . . . . . . . . . . . . . . 6

5.1 Cavities and Fractures . . . . . . . . . . . . . . 6

5.2 Method Selection . . . . . . . . . . . . . . . . . 6

5.3 Safety . . . . . . . . . . . . . . . . . . . . . . 7

5.4 Cement Slurry Weights and Curing Schedules . . . . 7

5.5 Casing Extraction... . . . . . . . . . . . . . . . 7

5.6 Well Construction Information. . . . . . . . . . . 7

6.0 EQUIPMENT, TOOLS AND SUPPIIES . . . . . . . . . . . . . 8

7.0 DOCUMENTATION . . . . . . . . . . . . . . . . . . . . . 8

3.0 PLUGGING AND ABANDONMENT . . . . . . . . . . . . . . . . . . 9

8.1 Site Preparation . . . . . . . . . . . . . . . . . 9

8.2 Equipment Decontamination . . . . . . . . . . . . . 9

8.3 Method A . . . . . . . . . . 10

8.3.1 Remove the Well Casing. . . . . . . . . 10

8.3 .2 Condition the Borehole. . . . . . . . . . 10

8.3.3. Set the Plug. . . . . . . . . . . . . 10

8.3.4 Remove the Surface/Conductor Casing . . . . 11

8.3.5 Verify Plug Depth . . . . . . . . . . . . . 11

8.3.6 Cap the Plug... . . . . . . . . . . . . . 11

8.4 Method B . . . . . . . . . . . . . . . . . . 11

8.4.1 Condition the Open-Hole Interval . . . . . . 12

8.4.2 Set the Lower Plug. . . . . . . . . . . . . 12

8.4.3 Remove the Well Casing . . . . . . . . . . . 12

8.4.4 Condition the Borehole. . . . . . . . . . . 12

8.4.5 Set the Upper Plug. . . . . . . . . . . . . 12

8.4.6 Remove the Surface/Conductor Casing . . . . 13

8.4.7 Verify Plug Depth . . . . . . . . . . . . . 13

8.4.8 Cap the Plug . . . . . . . . . . . . . . . . 13

8.5 Method $C$. . . . . . . . . . 13

8.5.1 Remove the Well Casing. . . . . . . . . . 14

8.5 .2 Condition the Borehole . . . . . . . . . . . 14

8.5.3 Set the Plug. . . . . . . . . . . . . . . 14 


\section{Y-I2 PLANT GROUNDWATER PROTECTION PROGRAM}

IITLE: Well ミlugging and Abandonment Procedure
G-003

Rev. 1,

October 1994

Page 3 of 18

\section{CONTENTS (CONt'd)}

Page

8.5.4 Kemove the Surface/Conductor Casing . . . . 14

8.5.5 Verify Plug Depth . . . . . . . . . . . . . 15

8.5 .6 Sap the Plug. . . . . . . . . . . . . . . . 15

8.6 Method D . . . . . . . . . . . . . . . . . 15

8.6.I Condition the Open-Hole Interval. . . . . . 15

8.6.2 Set the Lower Plug . . . . . . . . . . . . . 15

8.6.3 Remove the Surface Casing . . . . . . . . . 16

8.6 .4 Sondition the Borehole . . . . . . . . . . . 16

8.6.5 Set the Upper Plug . . . . . . . . . . . . . 16

8.6.6 Remove the Conductor Casing . . . . . . . . 16

8.6.7 Verify Plug Depth . . . . . . . . . . . . . 17

8.6.8 Cap the Plug.. . . . . . . . . . . . . . 17

9. 0 ACCEPTANCE CRITERIA . . . . . . . . . . . . . . . . . . . . 17

10.0 POST PERFORMANCE WORK ACTIVITIES . . . . . . . . . . . . 17

11.0 RECORDS . . . . . . . . . . . . . . . . . . . . . . . . . 18 


\section{Y-I2 PLANT GROUNDWATER FROTECTION PROGRAM}

TITLE: Well Plugging and Abandonment Procedure
G-003

Rev. i, Octoder 1994

Page 4 of 18

\subsection{PURPOSE}

This procedure contains guidelines and methods for. well plugging and abandonment (P\&A) at the Oak Ridge Y-12 Plant. Welis of similar construction materials and design are classified into one of four groups, and a specific P\&A method is defined for each group. The methods are designed to remove all well materials, seal the borehole to prevent fluid migration into or between water-bearing zones, and to minimize the amount of waste-materials generated during P\&A operations.

\subsection{APPLICABILITY}

This procedure applies to all wells at the $Y-12$ Plant which are designated for $P \& A$ by the $Y-12$ Plant Groundwater Protection Program Manager (GWPPM) or authorized designee.

\subsection{DEEINITIONS}

Annular seal - material (grout or cement) which prevents fluid migration through the space between the well casing and borehole wall or outer casing.

Conductor Casing - an initial casing, typically steel or PVC, installed in the unconsolidated zone to support the borehole and provide drilling rig stability. This casing may be removed during completion of the well or grouted in place.

Containment syatem - excavated pit, drums, tanks or other containers used to collect and contain drill cuttings and fluids generated during P\&A.

Diverter Assembly - apparatus used to direct drill cuttings and fluids to the containment system.

Groundwater Protection Program (GWPP) - program established to monitor groundwater quality and hydrologic conditions at the $Y-12$ Plant.

GWPP Manager (GWPPM) - person responsible for day-to-day management of the $Y-12$ Plant GWPP. 


$$
\begin{aligned}
& \because-: 2 \text { EIANT GROUNDWATER EROTECTION PROGRAM|G-003 }
\end{aligned}
$$

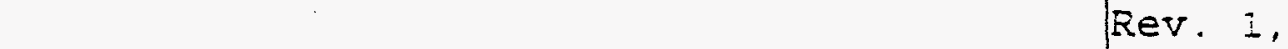

$$
\begin{aligned}
& \text { TITIE: Nei: Elugging and Abandonment Erocedure }
\end{aligned}
$$

On-Site Geologist - a professionai geoiogist, zegistered in the state of Tennessee, responsible for fieid supervision JE PSA operations.

Open-Hole Interval - the bottom section of a weIl drilled in competent rock unsupported by well screen or casing.

Primary Ingpection Item - those monitoring weIl components that are critical to the collection of representative groundwater samples and/or hydrologic data from the well. Includes the well casing and annular grout seal, well security, and the downhole condition of the well.

Protective Well Casing - a section of Iarge diameter steel or polyvinyl chloride (PVC) pipe that is emplaced over the upper end of a smaller diameter monitoring well casing to provide structural protection to the well and restrict unauthorized access to the well.

Surface Casing - steel or PVC piping set from the ground surface into the top of bedrock to support the unconsolidated section of the borehole. The surface casing in a core hole extends into bedrock to the top of the open-hole interval.

Tremie Method - a method for placing cement in the borehole. Cement is pumped through a small diameter pipe (usually 2 -in or less) extending to at inast 1 - ft above the bottom of the borehole or the top of a previously placed cement plug. The pipe is raised as the cement is emplaced. Use of this method reduces the potential for the cement to bridge and ensures placement of cement along the entire length of the borehole.

Washover Pipe - a drill pipe which fits around the well casing and is used to drill out the annular grout seal.

Well Casing - steel, stainless steel or PVC piping which provides unobstructed access to the monitored interval.

\subsection{REFERENCES}

4.1 Aller, Iinca, Truman W. Bennete, Gene Hackett, Rebecca J. Eetty, Jay H. Lehr, Felen Sedoris, and David M. Nielsen. Handbook of Suggested Practices for the Desian and Inscallation of Groundwater Monitoring Wells, National Water Well Associacion, Dublin, Ohio, $398 \mathrm{p}$. 


\section{Y-:2 FLANT GROUNDWATER PROTECTION PROGRAM}

TIIIE: Weil Plugging and Abandonment ミrocedure

G-003

Rev. : October 2994 Page 6 of 18

4.2 Jriscoil, Fletcher G. 1986. Groundwater and Wells, Johnson Division, St. Zaui, Minnesota, 1089 .

4.3 Martin Marietta Energy Systems, Inc. 1987. Environmental Surveiliance ?rocedures cuality Control Program, $\mathrm{ESH} / \mathrm{SUB} / 87 / 21706 / 1$.

4.4 Martin Marietta Energy Systems, Inc. 1987. Plugging and Abandonment Procedures for the Oak Ridge $Y-12$ Plant, Y/TS-53I.

4.5 Martin Marietta Energy Systems, Inc. 1994. Monitoring Well Inspection and Maintenance Plan, $Y-12$ Plant, Oak Ridge, Tennessee (Revised), Y/TS-1215.

4.6 Halliburton Services, Inc., 1981, Halliburton Cementing Tables, Little's, Duncan, Oklahoma.

4.7 Jones, S.B., B. K. Thompson, and S. M. Field, 1994, Updated Subsurface Data Base for Bear Creek Valley. Chestnut Ridge, and Parts of Bethel Valley on the U.S. Department of Energy Oak Ridge Reservation, Y/TS-881/R2.

\subsection{PRECAUTIONS AND LIMITATIONS}

\section{I Cavities and Fractures}

Cavities, Eractures, joints, bedding planes, or other voids may be encountered during removal of the well casing and reaming of the borehole, resulting in a greater volume of cement to plug the borehole than calculated from the borehole depth and diameter. Additionally, lost-circulation additives may be required to minimize fluid loss during P\&A operations.

\subsection{Method Selection}

Because of differences in well construction and conditions that may occur during drilling operations, not all of the monitoring wells at the $Y-12$ plant can be classified into one of the four categories of well construction. A flexible policy is necessary to determine the most appropriate $P \& A$ method for each well and to allow some deviation from the specified method as conditions warrant. 


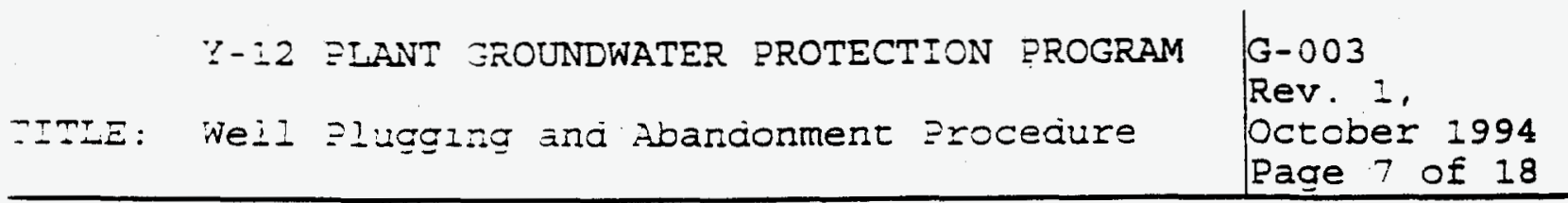

5.3 Safety

Estabi sned safety standards and requirements of Martin Marietza Energy systems, Inc., the Department of Energy (DOE), and the Occupational Safety and Health Administration (OSHA) will apply to all P\&A field operations as outlined in Health and Safety Plan for Well Installation and Plugging and Abandonment Activities, $Y-$ 12 Plant, Oak Ridge, Tennessee (Y/SUB/92-99928C(YII)/I, July 1992 .

\subsection{Cement Slurry Weights and Curing Schedules}

The length of the column of cement emplaced at one time should not exceed 300 ft so that the weight of the cement is less than the fracture pressure of the monitored formation. This will also minimize infiltration of cement into the formation. Cement cure times shall be determined by the on-site geologist. Cure times will be specified depending on temperature and required compressive strength using guidelines established in Reference 4.6 .

\subsection{Casing Extraction}

Certain monitoring welis have been constructed using substandard annular seals or no annular seal. Casings in these wells may be extracted without use of overwashing techniques. In cases where the construction of the well allows, an attempt to extract the well casing may be made using the drilling rig head and appropriate lifting device, such as lifting bell, clevis, wire rope, or chain. Casing extraction jacks may alternately be used. Drilling rig leveling jacks or winches shall not be used to attempt to extract casings prior to overwashing. The decision to attempt to extract a well casing shall be made by the on-site geologist, in conjunction with the GWPDM or authorized designee, and documented as specified in Section 7.0 .

\subsection{Well Construction Information}

Data contained in Reference 4.7 is compiled from best available records. However, erroneous and missing well construction data exists, particulariy for older wells that Dre-date the $G N$ Series. Where well construction data is unavailable, best technical juagment as to casing 


\section{Y-I2 FLANT GROUNDWATER PROTECTION PROGRAM}

FITLE: NeII Elugging and Abandonment Procedure

G-003

Rev. Z,

October 1994

Page 8 of 18

set points or weil depths will be empioyed by the on-site geologist in consuitation with the GWPPM or authorized designee. As a result, deviations from the standard P\&A likeiy will be required. All deviations shall be recorded as outined in section 9.0.

\subsection{EQUIPMENT, TOOLS AND SUPPLIES}

6.1 Fully Equipped Drilling Rig: includes but is not limited to drill bits, washover pipe, diverter assembly, etc.

6.2 Grouting Suppiies and Equipment: cement, additives, potable water, mixer, pump, and tremie pipe.

6.3 Containment System (as required): excavated containment pit, drums, tanks, and/or other containers.

6.4 Safety Equipment (as required): includes but is not limited to safety shoes, tyvek coveralls, protective eyewear, hard hat, and rubber gloves.

6.5 Decontamination Equipment (as required): includes but is not limited to steam cleaner, potabie water, and mild detergent.

\subsection{DOCUMENTATION}

7.1 A Well Plugging and Abandonment Request Form is used to initiate $P \& A$ activities, and is completed by the $Y-12$ Plant GWPPM or authorized designee if: (1) a well impedes site operations, construction or closure, (2) inspection of a well has indicated significant damage to or deterioration of a Primary Inspection Item, or (3) the Y-12 Plant GWPPM or authorized designee determines that P\&A of a well is warranted for other reasons. The completed form is transmitted to the on-site geologist when $P \& A$ operations are scheduled.

7.2 Before P\&A operations begin, $a$ Well Plugging and Abandonment Waste Management Plan is completed by the Y12 Plant GWPPM or authorized designee. The plan inciudes: (1) the estimated volume of cuttings and fluids that will be generated during P\&A, (2) the types and concentrations of contaminants (if any) known to be present in the well, (3) the appropriate waste containment method required during P\&A operations (i.e., 


\section{$\because-: 2$ PLANT GROUNDWATER EROTECTION FROGRAM G-003 \\ Rev. :, \\ October $=994$

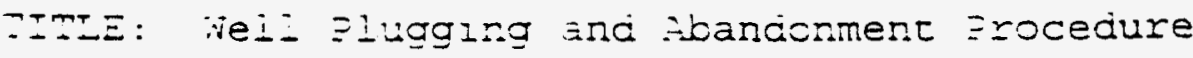

ijscharge to ground surtace or containment system), (4) an estimate di the rumier and types of samples le.g., zuttings) to be collected during P\&A and the required anaiyses of the sampies prior $=0$ disposal or treatment, and $(5)$ the proposed jisposition or treatment of any containerized materiais.

7.3 Well Plugging and Abandonment Diagrams are completed by the Y-I2 Plant GWPP Manager or authorized designee, and the on-site geologist. Before P\&A operations begin, the Y-12 Plant GWPP Manager or authorized designee completes the following sections of the diagram: (1) the well zocation isize), (2) the drilling subcontractor, (3) the rationale for P\&A of the well, (4) the P\&A method inciuding any proposed deviations from the specified method), and (5) applicable well construction details (e.g., borenole diameter). During P\&A operations, the on-site geologist completes the diagram with specific $P \& A$ details for the well (e.g., depth to the top of the cement glug).

7.4 A Well Plugging and Abandonment Activity/Progress Report is completed by the on-site geologist and includes descriptions of the daily activities performed during P\&A operations.

\subsection{PLUGGING AND ABANDONMENT}

\subsection{Site Preparation}

8.1.1 Confirm well identification and site access, and mobilize drilling and grouting equipment to the well site.

8.1.2 Remove the surface features from the well (lock, well cap, guard posts, surficial concrete pad, protective well casing or manhole coverl as applicable.

8.1.3 If specified in the Weli Plugging and Abandonment Waste Management Flan, set up the diverter assembly and the containment system.

8.2 Equipment Decontamination

If specified in the Well Plugging and Abandonment Waste Management Plan, decontaminate the drilling and assoclaced equipment e.g., drill bits, jrill rods, 


\section{$\because-I 2$ ZIANT GROUNDWATER EROTECTION EROGRAM | $\mid \begin{aligned} & \text { G-003 } \\ & \text { ReV. I. }\end{aligned}$ Nei: Elugging and Abandonment Erocedure \\ October 1994 Page $: 0$ of 18}

zremie zipel winen $2 \& A$ operations at eacn weil have been zompler@a.

\subsection{Method A}

Method $A$ is for weils constructed of 7 inch (in) outside diameter (OD) or smaller steel or stainless steel well casing, and typicaliy completed with 5 to 20 -ft well screens and sand Eilter packs. Wells completed in bedrock may also have 8 - to 12 -in-OD steel or PVC surface casing extending from ground surface to the top of bedrock. Some wells may also be completed with a conductor casing.

\subsubsection{Remove the Well Casing}

Drill out the annular grout seal using a washover pipe advanced to the bottom of the borehole. Retrieve the washover pipe and remove the well casing. Staged removal of the casing string may be necessary if it cannot be removed in one operation. In the event that a borehole is deviated, stainless steel casing may be drilled out with a tri-cone drill bit. If this approach is feasible, the bit size must be at least 0.25 in larger than the original borehole diameter to ensure that the casing and annular grout seal are zompletely removed.

\subsubsection{Condition the Borehole}

If the well was completed in bedrock, ream the borehole with a tri-cone drill bit that is at least 0.25 -in larger in diameter than the original borehole. This will expose fresh bedrock and help ensure an effective bond between the cement plug and the borehole wall.

8.3.3 Set the Plug

Tremie API Class A neat cement, mixed with potable water to a slurry density of 12 to 15 pounds per gallon (Ibs/gal), from the bottom of the borehole. If no surface/conductor casing is present, Eremie the cement to within $4 \mathrm{ft}$ of ground surface. IE a surface/conductor casing is oresent, =remie the cement to within 4 ft of the cottom of the casing. 
Y-I2 PLANT GROUNDWATER PROTECTION PROGRAM

IIILE: NelI Plugging and Abandonment procedure

G-003

Rev. 1, October 1994

Page 11 of 18

\subsubsection{Remove the Surface/Conductor Casing}

-E the weil was completed with surface/conductor casing, drill out the annular grout seal using a washover pipe advanced to the bottom of the casing. Retrieve the washover pipe and remove the casing. Using a tri-cone drill bit at least 0.25 -in larger in diameter than that of the original borehole, ream the borehole to the top of the existing cement plug. Tremie cement, mixed to a density of 12 to $15 \mathrm{Ibs} / \mathrm{gal}$, from the zop of the existing plug to within 4 ft of the ground surface (or bottom of conductor casing, if removing a surface casing).

It may be possible to remove PVC casing by drilling it out with a tri-cone drill bit. If this approach is feasible, the bit size must be at least 0.25 -in larger than the original borehole diameter to ensure that the casing and annular grout seal are completely removed.

\subsubsection{Verify Plug Depth}

Measure the depth to the top of the cement plug to verify that it is within 4 ft of the ground surface. If not, add more cement until the specified depth is reached.

\subsubsection{Cap the Plug}

Fill the remainder of the borehole to ground surface with compacted non-contaminated soil.

\subsection{Method B}

Method $B$ is for wells constructed of 7-in-oD or smaller steel or PVC well casing completed with open-hole intervals in competent bedrock. The well casing typicaliy extends from the ground surface to the top of the open-hole interval, which typically extends from 5 to 100 ft below the bottom of the well casing. The wells may also be completed with 8 - to 12 -in-OD steel or PVC surface casing extending from ground surface to the top of bedrock. Some wells may also be completed with a conductor casing. 


\section{Y-12 PLANT GROUNDWATER PROTECTION PROGRAM}

IITLE: Well Plugging and Abandonment Procedure
G-003

Rev. 1, October 1994

\subsubsection{Condition the Open-Hole Interval}

Lower a drill string and tri-cone drill bit into the well. Circulate air and potable water containing additives such as QUIK-GEL or QUICKMUD to remove any old cuttings and debris that may have accumulated at the bottom of the well. After the initial circulation, drill approximately 1 ft below the bottom of the well to expose fresh rock, and repeat the well circulation procedure to remove the cuttings.

\subsubsection{Set the Lower Plug}

Tremie API Class A neat cement, mixed with potable water to a slurry density of 12 to 15 Ibs/gal, from the extended bottom of the openhole interval to within 4 ft of the bottom of the well casing.

\subsubsection{Remove the Well Casing}

Drill out the annular grout seal surrounding the well casing using a washover pipe advanced to the top of the open-hole interval. Retrieve the washover pipe and remove the casing. Staged removal of the casing string may be necessary if it cannot be removed in one operation.

It may be possible to remove PVC well casing by drilling it out with a tri-cone drill bit. If this approach is feasible, the bit size must be at least 0.25 -in larger than the original borehole diameter to ensure that fresh bedrock is exposed and that the casing and annular grout seal are completely removed.

\subsubsection{Condition the Borehole}

Ream the borehole with a tri-cone drill bit that is at least 0.25 -in larger in diameter than the original borehole. This will expose fresh bedrock and help ensure an effective bond between the cement plug and the borehole wall.

8.4.5 Set the Upper Plug

Tremie cement, mixed to a density of 12 to 15 lbs/gal, from the top of the lower plug. If no surface/conductor casing is present, tremie the 


\section{Y-I2 PLANT GROUNDWATER EROTECTION PROGRAM}

TITLE: Weil Plugging and Abandonment Procedure

G-003

Rev. 1 ,

October 1994

Page 13 of 18

cement to within 4 ft of ground surface. If a surface/conductor casing is present, tremie the cement to within 4 Et of the bottom of the casing.

\subsubsection{Remove the Surface/Conductor Casing}

If the well was completed with surface/conductor casing, drill out the annular grout seal using a washover pipe advanced to the bottom of the casing. Retrieve the washover pipe and remove the casing. Using a tri-cone drill bit at least 0.25 -in larger in diameter than the original borehole, ream the borehole to the top of the existing cement plug. Tremie cement, mixed to a density of 12 to $15 \mathrm{lbs} / \mathrm{gal}$, from the top of the existing plug to within 4 ft of the ground surface (or bottom of the conductor casing, if removing a surface casing).

It may be possible to remove PVC casing by drilling it out with a tri-cone drill bit. If this approach is feasible, the bit size must be at least 0.25 -in larger than the original borehole diameter to ensure that the casing and annular grout seal are completely removed.

\subsubsection{Verify Plug Depth}

Measure the depth to the top of the cement plug to verify that it is within 4 ft of the ground surface. If not, add more cement until the specified depth is reached.

\subsubsection{Cap the Plug}

Fill the remainder of the borehole to ground surface with compacted non-contaminated soil.

\subsection{Method C}

Method $C$ is for wells constructed of 7-in-OD or smaller PVC well casing, and typicaily completed with 5 to 20 -ft well screens and sand filter packs. Wells completed in bedrock may also have 8 to $12-i n-O D$ steel or PVC surface casing extending from ground surface to the top of bedrock. Some wells may also be completed with a conductor casing. 


\section{Y-12 PLANT GROUNDWATER PROTECTION PROGRAM}

TITLE: well Plugging and Abandonment Erocedure

G-003

Rev. 1, October 1994 Page 14 of 18

\subsubsection{Remove the Well Casing}

Drill out the annular grout seal around the well casing using a washover pipe advanced to the bottom of the borehole. Retrieve the washover pipe and remove the well casing. Staged removal of the casing string may be necessary if it cannot be removed in one operation.

It may be possible to remove the PVC well casing by drilling it out with a tri-cone drill bit. If this approach is feasible, the bit size must be at least 0.25 -in larger than the original borehole diameter to ensure that fresh bedrock is exposed (bedrock wells only) and that the casing and annular grout seal are completely removed.

\subsubsection{Condition the Borehole}

If the well was completed in bedrock, ream the borehole with a tri-cone drill bit that is at least 0.25 -in larger in diameter than the original borehole. This will expose fresh bedrock and help ensure an effective bond between the cement plug and the borehole wall.

\subsubsection{Set the Plug}

Tremie API Class A neat cement, mixed with potable water to a slurry density of 12 to $15 \mathrm{lbs} / \mathrm{gal}$, from the bottom of the borehole. If no surface/conductor casing is present, tremie the cement to within 4 ft of ground surface. If a surface/conductor casing is present, tremie the cement to within $4 \mathrm{ft}$ of the bottom of the casing.

\subsubsection{Remove the Surface/Conductor Casing}

If the well was completed with surface/conductor casing, drill out the annular grout seal using a washover pipe advanced to the bottom of the casing. Retrieve the washover pipe and remove the casing. Using a tri-cone drill bit at least 0.25 -in larger in diameter than the original borehole, ream the borehole to the top of the existing cement plug. Tremie cement, mixed to a density of 12 to 15 ibs/gal, from the top of the existing plug to within 4 ft of the ground 


\section{Y-I2 PLANT GROUNDWATER PROTECTION EROGRAM G-003 \\ Rev. 1, October 1994 \\ FITLE: Well Plugging and Abandonment Procedure}

surface for bottom of conductor casing if removing a surface casing).

it may be possible to remove PVC casing by arilling it out with a tri-cone drill bit. If this approach is Eeasible, the bit size must be at least 0.25 -in larger than the original corehole diameter to ensure that the casing and annular grout seal are completely removed.

\subsubsection{Verify Plug Depth}

Measure the depth to the top of the cement plug to verify that it is within 4 ft of the ground surface. If not, add more cement until the specified depth is reached.

\subsubsection{Cap the Plug}

Fill the remainder of the borehole from the top of the cement plug to ground surface with compacted non-contaminated soil.

\subsection{Method D}

Method $\supset$ is for exploratory core holes constructed of 4.5-in-OD or smaller steel surface casing, which typically extends from ground surface into competent bedrock, with an open-hole interval below the bottom of the casing. The core holes may also have 8 to 12 -in-OD steel or PVC conductor casing extending through the unconsolidated material.

\subsubsection{Condition the Open-Hole Interval}

The open-hole interval of the core holes will not be conditioned (i.e.. fluid circulation or reamed to expose fresh bedrock). This would require the prior removal of the 4.5 -in-OD surface casing, which may risk collapse of the upper portion of the core hole before $P \& A$ operations are completed. In addition, core hole diameters are normally $3.5-$ in. or less, which are smaller than standard tri-cone bits.

8.6.2 Set the Lower Plug

Tremie API Class A neat cement, mixed with potable water to give a slurry density of 12 to is Ibs/gal, from the bottom of the open-hole 


\section{Y-12 PLANT GROUNDWATER EROTECTION PROGRAM}

G-003

Rev. 1,

TITLE: Well Elugging and Abandonment Procedure

Octoier 1994

Page 16 of 18

portion of the core hole. Because of the long open hole intervals in the core holes, the cement must be installed in stages of approximately 300 ft or less. During placement, tremie the cement Erom the bottom to the top of the particular interval being plugged, and allow the cement to set for 24 hours. In the final stage, tremie the cement to within 4 ft of the bottom of the surface casing.

\subsubsection{Remove the Surface Casing}

Drill out the annular grout seal around the surface casing using a washover pipe advanced to the bottom of the casing. Retrieve the washover pipe and remove the casing. Staged removal of the casing may be necessary if it cannot be removed in one operation.

\subsubsection{Condition the Borehole}

Ream the borehole to the top of the existing cement plug using a tri-cone drill bit that is at least 0.25 larger than the original borehole diameter. This will expose fresh bedrock and help ensure an effective bond between the cement plug and the borehole well.

\subsubsection{Set the Upper Plug}

Tremie cement, mixed to a density of 12 to 15 lbs/gal, from the top of the lower plug. If no conductor casing is present, tremie the cement to within 4 ft of ground surface. If a conductor casing is present, tremie the cement to within 4 ft of the bottom of the conductor casing.

\subsubsection{Remove the Conductor Casing}

If the core hole was completed with conductor casing, drill out the annular grout seal using a washover pipe advanced to the bottom of the conductor casing. Retrieve the washover pipe and remove the conductor casing. Using a tri-cone drill bit at least 0.25 -in larger in diameter than the original borehole, ream the upper portion of the borenole to the top of the existing cement plug. Tremie cement, mixed to a density of 12 to 15 lbs/gal, from the top of the 


\section{Y-I2 PLANT GROUNDWATER EROTECTION PROGRAM}

G-003

Rev. 1 ,

TITIE: Well Plugging and Abandonment Procedure

existing piug to within 4 ft of the ground surface.

It may be possible to remove PVC conductor casing by arilling it out with a tri-cone drill bit. If this approach is feasible, the bit size must be at least 0.25 -in larger than the original borehole diameter to ensure that the casing and annular grout seal are completely removed.

\subsubsection{Verify Plug Depth}

Measure the depth to the top of the cement plug to verify that it is within 4 ft of the ground surface. If not, add more cement until the specified depth is reached.

\subsubsection{Cap the Plug}

Fill the remainder of the borehole to the ground surface with compacted non-contaminated soil.

\subsection{ACCEPTANCE CRITERIA}

The on-site geologist will verify that P\&A operations were performed in accordance with the specified method. Any deviations from the specified $P \& A$ method must be pre-approved by the Y-I2 Plant GWPPM or authorized designee. Requests for deviations may be verbal, but must be recorded immediately in the field $\log$ book and include date, time, and authorizing personnel. Deviations will also be noted on Activity/Progress Forms and P\&A Diagrams as appropriate.

\subsection{POST PERFORMANCE WORK ACTIVITIES}

10.1 The on-site geologist will submit the well Plugging and Abandonment documentation to the $Y-12$ Plant GWPPM or authorized designee.

10.2 Waste materials generated during P\&A will be disposed of in accordance with the Well Plugging and Abandonment waste Management Plan. 


\section{Y-I2 PLANT GROUNDWATER PROTECTION PROGRAM}

TITIE: Well Plugging and Abandonment Procedure
$\mathrm{G}-003$

Rev. 1, October 1994 Page 18 of 18

11.0 RECORDS

11.1 Well Plugging and Abandonment Request Form

11.2 Well Plugging and Abandonment Waste Management Plan

11.3 Well Plugging and Abandonment Diagram

11.4 Well Plugging and Abandonment Activity/Progress Report 


\section{C.2 Well Inspection Procedure}


Oak Ridge $\mathrm{Y}-12$ Plant Groundwater protection Program standard Practice procedure

Well Inspection Procedure

$$
\text { G-001 }
$$

Rev. 1., July 1994

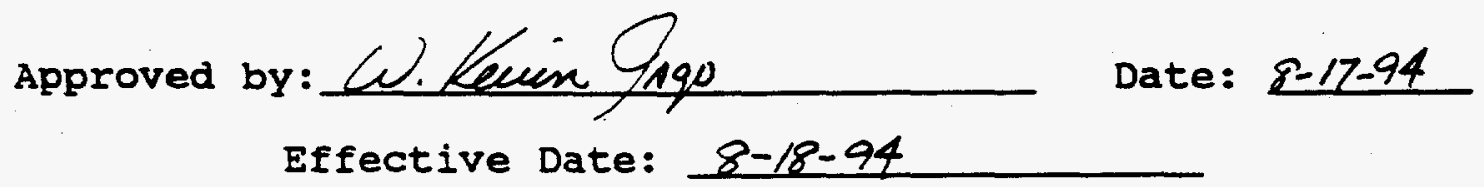

Record of Changes

\begin{tabular}{|c|c|c|c|c|c|c|c|}
\hline $\begin{array}{c}\text { Change } \\
\text { No. }\end{array}$ & $\begin{array}{c}\text { Affected } \\
\text { Pages }\end{array}$ & Approved Date & Expiration Date & $\begin{array}{c}\text { Change } \\
\text { No. }\end{array}$ & $\begin{array}{c}\text { Affected } \\
\text { Pages }\end{array}$ & $\begin{array}{c}\text { Approved } \\
\text { Date }\end{array}$ & $\begin{array}{c}\text { Expiration } \\
\text { Date }\end{array}$ \\
\hline \hline & & & & & & & \\
\hline & & & & & & & \\
\hline & & & & & & & \\
\hline
\end{tabular}

Next 3-year review required no later than: July 1997. 
Y-12 PLANT GROUNDWATER PROTECTION PROGRAM

TITLE: Well Inspection Procedure
G-001

Rev. 1, July 1994

Page 2 of 12

CONTENTS

Page

1.0 PURPOSE . . . . . . . . . . . . . . . . . . . . . . 3

2.0 APPLICABILITY . . . . . . . . . . . . . . . . . . . 3

3.0 DEFINITIONS . . . . . . . . . . . . . . . . . . . . . . . 3

4.0 REFERENCES . . . . . . . . . . . . . . . . . . . . . . 5

4.1 Use References . . . . . . . . . . . . . . . . 5

4.2 Source References . . . . . . . . . . . . . . . . 6

5.0 PRECAUTIONS AND LIMITATIONS . . . . . . . . . . . . . . . 7

5.1 Annular Seal . . . . . . . . . . . . . . . . . . 7

5.2 Constructed Well Depth . . . . . . . . . . . . 7

5.3 Incrustation . . . . . . . . . . . . . . . . . 7

5.4 Limits of Tape Measure . . . . . . . . . . . . . . . 7

5.5 Measurement Accuracy . . . . . . . . . . . . . 7

5.6 Safety .. . . . . . . . . . . . . . . . . 7

5.7 Well Access . . . . . . . . . . . . . . . . 8

6.0 PREREQUISITES . . . . . . . . . . . . . . . . . . . . . . . 8

6.1 Initial Inspection . . . . . . . . . . . . . . . . . 8

6.2 Subsequent Inspections . . . . . . . . . . . . . 8

7.0 TEST EQUIPMENT, TOOLS, AND SUPPLIES . . . . . . . . . . . . 8

8.0 ACTION STEPS . . . . . . . . . . . . . . . . . . . . . . . 9

8.1 Preparation . . . . . . . . . . . . . . . . 9

8.2 Inspection . . . . . . . . . . . . . . . . . . 9

9.0 ACCEPTANCE CRITERIA . . . . . . . . . . . . . . . 12

10.0 POST PERFORMANCE WORK ACTIVITIES . . . . . . . . . . . . 12

10.1 Documentation . . . . . . . . . . . . . . . . . . 12

10.2 Maintenance Work Inspection . . . . . . . . . . . . 12

10.3 Plugging and Abandonment Requests . . . . . . . . . 12 


\section{Y-I2 PLANT GROUNDWATER PROTECTION PROGRAM}

TITLE: Well Inspection Procedure

G-001

Rev. 1, July 1994

Page 3 of 12

\subsection{PURPOBE}

This is a procedure intended to establish a systematic method for inspecting the physical condition of a monitor well and to identify monitor-well maintenance needs that will extend the life of the well and ensure the collection of representative groundwater quality samples and hydrologic data from the well.

\subsection{APPLICABILITY}

This procedure is applicable to all monitor wells located at the $Y-12$ Plant.

3.0 DEFINITIONS

Annular seal - a grout seal installed between the well casing and borehole wall or outer casing.

Christy Box - steel or plastic box installed below the ground surface that allows access to the top of casing in a flushmounted well design.

concrete Pad - typically a neat cement or concrete pad at ground surface that surrounds the well casing or protective surface casing.

Constructed Depth - the distance from the top of the innermost well casing to the bottom of the screened or open interval as reported in: Updated Subsurface Data Base for Bear creek Valley, Chestnut Ridge, and Parts of Bethel Valley on the U.S. Department of Energy Oak Ridge Reservation, Y/TS$881(R 2)$, Auqust 1994 (or most recent version).

Flush-Kounted well - well head completion where the top of casing is below the ground surface.

Groundwater Protection Program (GWPP) - a program developed per DOE order 5400.1 to characterize the hydrogeology and monitor and protect groundwater quality at the Y-12 Plant.

GWPP Manager - person responsible for day-to-day management of the $y-12$ plant Groundwater Protection Program or authorized designee.

Guard Posts - posts placed around a well to prevent vehicular collision damage to the well. 


\section{Y-12 PIANT GROUNDWATER PROTECTION PROGRAM}

TITLE: Well Inspection Procedure

G-001 Rev. 1, July 1994 Page 4 of 12

Hasp - a welded fastening that allows a well cap to be locked to the well casing, or a hinged steel lid to be locked to the protective casing.

Incrustation - deposition of mineral matter on the well screen and/or casing, typically through chemical or biological reactions.

Lock - a waterproof, steel or brass fastening device that secures the well cap or protective-casing lid and prevents unauthorized access to the well.

Measured Depth - the distance from the top of innermost well casing to the bottom of the well as measured in the field.

Monitor well - a well installed to enable collection of groundwater samples and/or hydrologic data

(i.e., staticwater level).

Open-Hole Interval - a portion of a monitor well that contains no well casing through which groundwater enters the well and samples are obtained.

Primary Inspection Items - those components of a monitor well that are critical to the collection of representative groundwater quality samples and hydrologic information. Primary inspection items include the well casing and screen, hasp, lock, cap, well identification, and condition of the screened or open-hole interval.

Protective surface casing - a section of large-diameter steel pipe that is emplaced over the surface extension of a smaller diameter well casing to provide structural protection to the well and restrict unauthorized access to the well. A weep (hole) is usually located near the base of the casing to serve as a drain and prevent water from collecting inside the protective surface casing.

screened Interval - A portion of a monitor well that contains a slotted, perforated, or wire-wound section of casing (e.g., screen) through which groundwater enters the well and samples are obtained.

Secondary Inspection Items - those components of a monitor well which generally do not affect collection of representative groundwater quality samples or hydrologic information: these include well access, guard posts, and concrete pad. 
Y-12 PLANT GROUNDWATER PROTECTION PROGRAM

TITLE: Well Inspection Procedure

$G-001$

Rev. 1,

July 1994

Page 5 of 12

sediment Accumulation - accumulation of sand, silt, precipitates, or other debris in the bottom of the well.

Well Access - the means by which a well is accessible (e.g., gravel road).

Well cap - a removable cap or hinged steel lid used to cover a well casing.

well Casing - steel, stainless steel or PVC pipe which provides unobstructed access to the monitored interval.

Ne11 Identification - a stainless steel plate that is engraved with the well identification number and is attached to the outermost casing.

\subsection{REEERENCES}

\subsection{Use References}

1.1.1 "Comprehensive Groundwater Monitoring Plan for the Department of Energy $Y-12$ Plant Oak Ridge, Tennessee," $Y /$ SUB/90-00206C/5, September 1990.

4.1.2 "Calendar Year 1993 Groundwater Quality Report for the Bear Creek Hydrogeologic Regime, Y-12 Plant, Oak Ridge, Tennessee," Y/SUB/94-EAQ10C/1, Parts 1 and 2 .

4.1.3 "Calendar Year 1993 Groundwater Quality Report for the Chestnut Ridge Hydrogeologic Regime, $Y-12$ Plant, Oak Ridge, Tennessee," Y/SUB/94-EAQ10C/3, Parts 1 and 2 .

4.1.4 "Calendar Year 1993 Groundwater Quality Report for the Upper East Fork Poplar Creek Hydrogeologic Regime, $Y-12$ Plant, Oak Ridge, Tennessee," $Y /$ SUB/94-EAQ10C/2, Parts 1 and 2 .

4.1.5 "Oak Ridge $Y-12$ Plant Groundwater Protection Program Management Plan (Revised),"

$Y / S U B / 93-Y P 507 C / 4$, June 1993 (or most recent revision).

4.1.6 "Updated Subsurface Data Base for Bear Creek Valley, Chestnut Ridge, and Parts of Bethel Valley on the U.S. Department of Energy Oak Ridge Reservation," Y/TS-881(R2), August 1994 (or most recent revision. 


\section{Y-12 PLANT GROUNDWATER PROTECTION PROGRAM}

G-001

Rev. 1,

TITLE: Well Inspection Procedure

4.1.7 "Monitor Well Inspection and Maintenance Plan, Y-12 Plant, Oak Ridge, Tennessee (Revised)," Y/TS-1215, JulY 1994 .

\subsection{Source References}

4.2.1 Aller, Iinda, Truman W. Bennett, Gene Hackett, Rebecca J. Petty, Jay H. Lehr, Helen Sedoris, and David M. Nielsen "Handbook of Suggested Practices for the Design and Installation of Groundwater Monitoring Wells", NWWA, Dublin, Ohio, 398 p.

4.2.2 Driscoll, Fletcher G., 1986, "Groundwater and Wells", Johnson Division, st. Paul, Minnesota, $1089 \mathrm{p}$.

4.2.3 "Environmental Surveillance Procedures Quality Control Program," ESH/Sub/87/21706/1, February 1987.

4.2.4 Gass, Tyler E., Truman W. Bennett, James Miller and Robin Miller, 1980, "Manual of Water Well Maintenance and Rehabilitation Technology", NWWA, Dublin, Ohio, $247 \mathrm{p}$.

4.2.5 Nielsen, David M., 1991, "Practical Handbook of Groundwater Monitoring", Lewis Publishers, Chelsea, Michigan, $717 \mathrm{p}$.

4.2.6 U.S. Department of Energy, "Procedures for the Collection and Preservation of Groundwater and Surface Water Samples and for the Installation of Monitoring Wells", GJ/TMC-08 (Second Edition) UC70A, October 1985 .

4.2.7 U.S. Environmental Protection Agency, "Environmental Compliance Branch Standard operating Procedures and Quality Assurance Manual", Region IV, Athens, Georgia, February 1991.

4.2.8 U.S. Environmental Protection Agency, "RCRA Comprehensive Groundwater Monitoring Evaluation Document" (RCRA Groundwater Monitoring Systems), RCRA Enforcement Division, March 1988.

4.2.9 U.S. Environmental Protection Agency, "RCRA Facility Investigation (RFI) Guidance, Volumes I-IV", OSWER Directive 9502.00-6C, July 1987 . 


\section{Y-12 PLANT GROUNDWATER PROTECTION PROGRAM}

TITLE: Well Inspection Procedure
G-001

Rev. 1 ,

July 1994

Page 7 of 12

\subsubsection{U.S. Environmental Protection Agency, "RCRA Groundwater Monitoring Technical Enforcement Guidance Document", OSWER-9950.1, September 1986.}

\subsection{PRECAUTIONB AND LIMITATIONS}

\subsection{Anoular seal}

The downhole condition of the annular seal cannot be determined without geophysical techniques. Such evaluation is beyond the scope of this procedure.

\subsection{Constructed well Depth}

The reported constructed depth of a well may require confirmation or may be inaccurate as recorded in original well construction records.

\subsection{Incrustation}

The downhole condition of a well screen cannot be determined without remote sensing. Such evaluation is beyond the scope of this procedure.

\subsection{Limits of Tape Measure}

Some wells are completed at depths (i.e., > $300 \mathrm{ft}$ ) that cannot be measured with a flat, weighted steel or fiberglass measuring tape. Additionally, the depth of wells which contain large water columns (i.e., greater than $100 \mathrm{ft}$ ) also may not be measurable with a flat, weighted measuring tape. A circular, stainless steel or coated steel measuring cable shall be used for all wells greater than a $30.0 \mathrm{ft}$ depth and is preferabie for all vells.

\subsection{Measurement Accuracy}

Increased depth and large water columns decrease the accuracy of the well depth measurements.

\subsection{Safety}

Estaklished safety standards and requirements of Martin Marietta Corporation, DOE, and OSHA will apply to the inspection and maintenance of a monitor well. All field personiel will be provided with appropriate safety clothing, equipment, and training. 


\section{Y-12 PLANT GROUNDWATER PROTECTION PROGRAM G-001}

Rev. 1,

TITLE: Well Inspection Procedure

\subsection{Tell Access}

A well may be deemed inaccessible because of site conditions or operations.

\subsection{PREREQUIBITES}

\subsection{Initial Inspection}

If a well is currently scheduled for Plugging and Abandonment ( $P / A)$, inspection and maintenance of the well is not performed.

\subsection{Subsequent Inspections}

If a well is currently included in the comprehensive groundwater monitoring program, the well is classified as active and a well inspection is performed annually. If not, the well is classified as inactive and a well inspection is performed every three years. Wells for which the status changes from inactive to active will be inspected prior to monitoring.

\subsection{TEST EQUIPMENT, TOOLS AND SUPPLIES}

7.1 Documentation: Updated Subsurface Data Base (Y/TS-881/R2 or most recent revision), Well Inspection Maintenance Summary, Well Construction Data Summary, Well Inspection Checklist, Well Maintenance Request Form, Well Depth Measurement procedure (G-002), Active Well status Checklist, and Daily Activity Log.

7.2 Field Equipment: Well locks, keys to unlock wells, weighted steel or fiberglass measuring tape and/or cable, pens, indelible markers, and clip-board.

7.3 Personal Protective Equipment:

Required: Rubber gloves

Optional: Safety shoes, tyvek coveralls, protective eye-wear, hard hat.

7.4 Decontamination Equipment: Plastic ground cover, distilled water, wash bottles, mild detergent, and collection vessels for wash and rinse water. 


\section{Y-12 PLANT GROUNDWATER PROTECTION PROGRAM G-001}

Rev. 1,

TITLE: Well Inspection Procedure

\subsection{ACTION BTEPB}

\subsection{Preparation}

8.1.1 Identify wells to be inspected from the Well Inspection/Maintenance Summary.

8.1.2 Review Well Location Map(s) and Well Construction Data Summary to determine:

a. the well location;

b. the constructed depth of the well; and

c. length of the screen or open-hole interval for the well.

\subsection{Inspection}

8.2.1 On the Well Inspection Checklist, enter the inspection number for the well. The $Y-12$ plant GWPP Manager or authorized designee will assign the inspection number using the following format: two-digit number denoting the year followed by a dash followed by a three-digit number (example: 91-001). Inspection numbers for each well should be assigned consecutively (i.e., 91-001, 91-002, $91-003, \ldots$.$) .$

Complete the Well Information section of checklist using information from the updated Subsurface Data Base (for well number) and the Well Construction Data summary (for site, screened or open-hole interval length, and constructed well depth).

8.2.2 Verify that the monitor well is accessible by vehicle (active wells only). If construction, fencing, fallen trees, or site operation or closure activities have isolated the well, note on Well Inspection Checklist and report the finding to the $\Psi-12$ GWPP Manager or authorized designee. Otherwise, note any maintenance needs for well access road on well Inspection Checklist.

8.2.3 Inspect guard posts for damage, physical deterioration, paint degradation, and proper positioning (active wells only). Each post should be painted high-traffic yellow, and be a height above ground that is adequate to prevent vehicular collision damage. The guard posts should be situated between the well and each 


\section{Y-12 PLANT GROUNDWATER PROTECTION PROGRAM}

TITLE: Well Inspection Procedure

G-001

Rev. 1, July 1994

Page 10 of 12

traffic approach to the well. Complete appropriate section of Well Inspection Checklist.

8.2.4 Confirm that a stainless steel plate engraved with a legible well identification number is attached to the outermost casing of the monitor well. Through a comparison with the Updated Subsurface Data Base, confirm that the well number is correct. Complete appropriate section of Well Inspection Checklist.

8.2.5 Inspect the concrete pad for cracks and deterioration (active wells only). The top of the pad should be level or slope away from the casing to prevent ponding of rain water around the well casing. Complete appropriate section of Well Inspection Checklist.

8.2.6 Inspect the lock for corrosion and operation of the locking mechanism. If a lock is corroded and difficult to open, replace it. Do not use any lubricant to improve lock performance. Complete appropriate section of Well Inspection Checklist.

8.2.7 Inspect the integrity of the hasps, making certain that they are firmly welded to the well cap and/or the metal casing. Complete appropriate section of Well Inspection Checklist.

8.2.8 Inspect the condition of the well cap or hinged steel lid. Complete appropriate section of Well Inspection Checklist.

8.2.9 Inspect all above-ground well casings and protective surface casings (if present) for cracks, corrosion, breaks, bends, or any other signs of deterioration that may effect structural integrity. Inspect base of protective surface casing to locate weep. complete appropriate section of Well Inspection Checklist.

8.2.10 For flush-mounted wells, inspect traffic covers for presence of fasteners (bolts), excessive rust or deterioration, or any other notable damage. Covers should be securely bolted to the christy box.

8.2.11 For flush-mounted wells, inspect christy box for excessive rust or other damage. The concrete pad surrounding the christy box should be sloped as 


\section{Y-12 PLANT GROUNDWATER PROTECTION PROGRAM}

TITLE: Well Inspection Procedure

G-001

Rev. 1,

July 1994

Page 11 of 12

to minimize the potential for water accumulation inside of the box.

8.2.12 For flush-mounted wells, inspect the water-tight well cap for tightness and condition of the rubber seal. Caps should fit securely so that they cannot be turned by hand.

8.2.13 Inspect the annular seal for cracks, if visible, and by shaking the well casing. The casing should not easily move. Complete appropriate section of Well Inspection Checklist.

8.2.14 Put on rubber gloves.

8.2.15 Remove lock and well cap.

8.2.16 Verify that an established reference mark (measuring point) is on the top of the innermost well casing. If not, establish a mark with indelible marker on the well casing for future reference and notify the $Y-12$ Plant GWPP Manager or authorized designee.

8.2.17 Measure the well depth from the established reference mark to the bottom of the well and record on the checklist to the nearest 0.1 foot. Perform measurement in accordance with $\mathrm{Y}-12$ Plant We11 Depth Measurement Procedure (G-002).

8.2.18 Compare measured well depth to the constructed depth of the well by using the equation: Sediment Accumulation = Constructed Depth Measured Depth. The sediment accumulation divided by the screen or open-hole interval length must be less than 0.2 . Complete appropriate section of Well Inspection Checklist.

8.2.19 If any shaded yes/no answer box for each item on Well Inspection checklist is checked, complete Well Maintenance Request section of checklist noting if maintenance is needed for Primary or Secondary Inspection Item(s), or both.

Enter the maintenance request number for the well on the Well Inspection Checklist and Maintenance Request Form. The $\mathrm{Y}-12$ Plant GWPP Manager or authorized designee will assign maintenance request numbers using the following format: a two-digit number denoting the year followed by a 


\section{Y-12 PLANT GROUNDWATER PROTECTION PROGRAM}

G-001

Rev. 1,

TITLE: Well Inspection Procedure

dash followed by a three-digit number with a "p" (for Primary Inspection Item), or "S" (for Secondary Inspection Item), or "PS" (for both Primary and Secondary Inspection Items) suffix (examples: 91-001P, 91-001S, 91-001PS). Consecutive maiztenance request numbers for each well should be assigned (example: 91-001P, 91$0025,91-0035, \ldots$.$) .$

8.2.20 Sign and date Well Inspection Checklist.

\subsection{ACCEPTANCE CRITTERIA}

If none of the inspection items require maintenance, inspection of the well is complete.

\subsection{POST PERPORYANCE WORK ACTIVITIES}

\subsection{Documentation}

Compile Well Inspection Checklists and Well Maintenance Request Forms. Transfer appropr ate data from checklists and forms to the Well Inspection/Maintenance Summary. Submit all checklists, forms, and the completed well Inspection/Maintenance Summary to the $Y-12$ Plant GWPP Manager or authorized designee.

\subsection{Maintenance Work Inspection}

The Y-12 Plant GWPP Manager or authorized designee will schedule and coordinate all well maintenance activities. When requested maintenance has been completed, obtain original Well Maintenance Request Form from Y-12 plant GWPP Manager or authorized designee and inspect maintenance work performed.

\subsection{Plugging and Abandonment Requests}

If the $Y-12$ Plant GWPP Manager or author zed designee determines that, based upon consultations with field inspection personnel and a well site visit (if needed), a Primary Inspection Item is damaged or deteriorated beyond practical repair, the well may require plugging and abandonment. The $Y-12$ Plant GWPP Manager or authorized designee will prepare all plugging and Abandonment Request Forms and schedule and coordinate all related activities. 
C.3 Well Depth Measurement Procedure 
Oak Ridge Y-12 Plant Groundwater Protection Program standard Practice Procedure

We11 Depth Measurement Procedure G-002

Rev. 1., July 1994

Approved by: a). Kewingone $8-17-94$ Effective Date: $8-18-94$

Record of Changes

\begin{tabular}{|c|c|c|c|c|c|c|c|}
\hline $\begin{array}{c}\text { Change } \\
\text { No. }\end{array}$ & $\begin{array}{c}\text { Affected } \\
\text { Pages }\end{array}$ & $\begin{array}{c}\text { Approved } \\
\text { Date }\end{array}$ & $\begin{array}{c}\text { Expiration } \\
\text { Date }\end{array}$ & $\begin{array}{c}\text { Change } \\
\text { No. }\end{array}$ & $\begin{array}{c}\text { Affected } \\
\text { Pages }\end{array}$ & $\begin{array}{c}\text { Approved } \\
\text { Date }\end{array}$ & $\begin{array}{c}\text { Expiration } \\
\text { Date }\end{array}$ \\
\hline & & & & & & & \\
\hline & & & & & & & \\
\hline & & & & & & & \\
\hline
\end{tabular}

Next 3-year review required no later than: July 1997 
Y-12 PLANT GROUNDWATER PROTECTION PROGRAM|G-002

Rev. 1,

TITLE: Monitor Well Depth Measurement Procedure July 1994

Page 2 of 7

CONTENTS

Page

1.0 PURPOSE . . . . . . . . . . . . . . . . . . 3

2.0 APPLICABILITY . . . . . . . . . . . . . . . 3

3.0 DEFINITIONS . . . . . . . . . . . . . . . . 3

4.0 REFERENCES . . . . . . . . . . . . . . . . . . 4

4.1 Use References .. . . . . . . . . . . . . . . . . 4 4

4.2 Source References... . . . . . . . . . . . . . 4

5.0 PRECAUTIONS AND LIMITATIONS . . . . . . . . . . . 4

5.1 Constructed Well Depth . . . . . . . . . . . .4

5.2 Limits of Tape Measure . . . . . . . . . . . . . 4

5.3 Measurement Accuracy . . . . . . . . . . . . 5

5.4 Safety .. . . . . . . . . . . . . . . . 5

5.5 Well Access . . . . . . . . . . . . . . 5

6.0 PREREQUISITES . . . . . . . . . . . . . . . . 5

7.0 TEST EQUIPMENT, TOOLS, AND SUPPLIES . . . . . . . . . . 5

7.1 Documentation .. . . . . . . . . . . . . 5

7.2 Personnel Protection Equipment . . . . . . . . . 5

7.3 Field Equipment . . . . . . . . . . . . . . . . 6

7.4 Decontamination Equipment . . . . . . . . . . . 6

8.0 ACTION STEPS . . . . . . . . . . . . . . . . . 6

9.0 ACCEPTANCE CRITERIA . . . . . . . . . . . . . . . . 6

10.0 POST PERFORMANCE WORK ACTIVITIES . . . . . . . . . . . 7

11.0 RECORDS . . . . . . . . . . . . . . . . . 7 
Y-12 PLANT GROUNDWATER PROTECTION PROGRAM|G-002

Rev. 1,

TITLE: Monitor Well Depth Measurement Procedure July 1994

Page 3 of 7

\subsection{PURPOBE}

This procedure is a standardized method for determining the measured depth of a groundwater monitoring well. The measured depth of a well, when compared to the constructed depth of the well, provides an indication of sediment accumulation or obstructions within the well.

\subsection{APPLICABIIITY}

Measuring well depth is applicable to all monitor wells located at the $\mathrm{Y}-12$ Plant.

\subsection{DERINITIONS}

Constructed Depth - the distance from the top of the innermost well casing to the bottom of the screened or open interval as reported in: Updated Subsurface Data Base for Bear Creek Valley, Chestnut Ridge, and Parte of Bethel Valley on the U.S. Department of Energy Oak Rldge Reservation, Y/TS-881(R2), Auqust 1994 (or most recent revision).

Groundwater Protection Program (GWPP) - a program developed per DOE Order 5400.1 to characterize the hydrogeology and monitor and protect groundwater quality at the Y-12 Plant.

GWPP Manager - person responsible for day-to-day management of the $\mathrm{Y}-12$ Plant Groundwater Protection Program or authorized designee.

Measured Depth - the distance from the top of the innermost well casing to the bottom of the well as measured in the field.

sediment Accumulation - accumulation of sand, silt, precipitates, or other debris in the bottom of the well.

Nell Cap - a removable cap used to cover a well casing.

well Casing - steel, stainless steel, or PVC pipe which provides unobstructed access to the monitored interval.

We11 Identification - a steel plate embossed with the well identification number that is attached to the outermost casing. 


\section{Y-12 PLANT GROUNDWATER PROTECTION PROGRAM|G-002}

TITLE: Monitor Well Depth Measurement Procedure

Rev. 1 , July 1994

Page 4 of 7

\subsection{REREREMCES}

\subsection{Use References}

4.1.1 "Updated Subsurface Data Base for Bear Creek Valley, Chestnut Ridge, and Parts of Bethel Valley on the U.S. Department of Energy oak Ridge Reservation", Y/TS-881(R2), August 1994 (or most revision).

4.1.2 "Monitor-Well Inspection and Maintenance Plan, Y-12 Plant, Oak Ridge, Tennessee (Revised)", Y/TS-1215, JulY 1994

\subsection{Source References}

1.2.1 Driscoll, Fletcher G., 1986, "Groundwater and Wells", Johnson Division, st. Paul, Minnesota, $1089 \mathrm{p}$.

4.2.2 "Environmental Surveillance Procedures Quality Control Program", ESH/Sub/87/21706/1, February 1987 .

4.2.3 Gass, Tyler E., Truman W. Bennett, James Miller and Robin Miller, 1980, "Manual of Water Well Maintenance and Rehabilitation Technology", NWWA, Dublin, Ohio, 247 p.

4.2.4 U.S. Environmental Protection Agency, "A Compendium of Superfund Field operations Methods", EPA/540/P-87/001, 1987.

4.2.5 U.S. Environmental Protection Agency, "RCRA Groundwater Monitoring Technical Enforcement Guidance Document", OSWER-9950.1, September 1986.

\subsection{PRECAUTIONS AND LIKITATIONB}

\subsection{Constructed Well Depth}

The reported constructed depth of the well may require confirmation or may be inaccurate as recorded in original well construction records. 
Y-12 PLANT GROUNDWATER PROTECTION PROGRAM|G-002 Rev. 1. TITLE: Monitor Well Depth Measurement Procedure July 1994

\subsection{Limits of Tape Measure}

Some wells are completed at depths (i.e., > $300 \mathrm{ft}$ ) that cannot be measured with a flat, weighted steel or fiberglass measuring tape. Additionally, the depth of wells which contain large water columns (i.e., greater than $100 \mathrm{ft.}$ ) also may not be measurable with a flat, weighted measuring tape. A stainless steel or coated steel measuring cable shall be used for all wells greater than a 300-foot depth and is preferable for all wells.

\subsection{Measurement Accuracy}

Increased depth and large water columns decrease the accuracy of the well depth measurement.

\subsection{Bafety}

Established safety standards and requirements of Martin Marietta Corporation, DOE, and OSHA will apply to the process of obtaining the measured depth of a monitor well. All field personnel will be provided with appropriate safety clothing, equipment, and training.

\subsection{Well Access}

A well may be deemed inaccessible because of site conditions or operations.

\subsection{PREREQUISITES}

All monitor wells will have the measured depth determined during a scheduled well inspection.

\subsection{TEST EQUIPMENT, TOOLS AND SUPPIIES}

7.1 Documentation: Well Construction Data Summary, Updated Subsurface Data Base, $Y / T S-881(R 2)$ (or most recent version), Daily Activity Logbook, and Monitor-Well Inspection Checklist.

7.2 Personnel Protection Equipment:

Required: rubber gloves

Optional: safety shoes, tyvek coveralls, hard hat, and protective eye-wear. 
Y-12 PLANT GROUNDWATER PROTECTION PROGRAM|G-002

Rev. 1,

TITLE: Monitor Well Depth Measurement Procedure July 1994

Page 6 of 7

7.3 Field Equipment: Keys to unlock wells, indelible marker, pen, clipboard,- and weighted fiberglass or steel measuring tape(s) and/or cable (the weight will be stainless steel or other approved inert material and have a blunt end facing down).

7.4 Decontamination Equipment: plastic ground cover, de-ionized water, mild detergent, and wash and rinse water collection vessels.

\subsection{ACTION 8TEPS}

8.1 Preparation: Review Well Construction Data Summary and Updated Subsurface Data Base to obtain the constructed depth of the well and determine the well location.

8.2 Record well number and date.

8.3 Put on rubber gloves.

8.4 Remove well lock and well cap.

8.5 Locate the reference mark at the top of the innermost well casing. If a reference mark is not present, make one with indelible marker, and notify $Y-12$ Plant GWPP Manager or authorized designee.

8.6 Select the appropriate length measuring tape and/or cable.

8.7 Slowly lower the weight into the well until the bottom of the well is encountered as indicated by slack in the tape measure or a solid impact.

8.8 When slack or impact occurs, slowly lift the tape until the tape becomes taut. Raise and lower the tape until the point of tension release becomes clearly defined.

8.9 Hold the tape to the reference mark on the casing.

8.10 Record the measurement to the nearest $0.1 \mathrm{ft}$ as the measured well depth in the Daily Activity Logbook and/or Well Inspection Checklist.

8.11 Repeat steps $8.6-8.9$ several times to ensure an accurate measurement. Readings should remain constant (i.e., within $0.1 \mathrm{ft}$ ). 


\title{
Y-12 PLANT GROUNDWATER PROTECTION PROGRAM|G-002
}

Rev. 1,

TITLE: Monitor Well Depth Measurement Procedure July 1994

Page 7 of 7

8.12 Remove the measuring tape from the well and decontaminate in accordance with ESP-900.

8.13 Close well cap and replace lock.

\subsection{ACCEPTANCE CRITERIA}

An acceptable measured depth of a well is achieved when the range of three or more consecutive measurements are within $0.1 \mathrm{ft}$.

\subsection{PO8T-PERPORYAYCE ACTIVITIES}

Report to the Y-12 GWPP Manager or authorized designee those wells with significant (i.e., greater than $1 \mathrm{ft.}$ ) differences between the constructed well depth and the measured well depth.

\subsection{RECORDS}

\author{
11. 1 Daily Activity Log \\ 11.2 Well Inspection Checklist
}


APPENDIX D

SAMPLING AND ENVIRONMENTAL SUPPORT DEPARTMENT
OPERATING PROCEDURE - GROUNDWATER SAMPLING

0 


\section{GROUNDWATER SAMPLING \\ SESD-TP-8204 \\ REV. 0}

Written by:

M. E. Cleveland

Sponsor:

C. B. Bryan

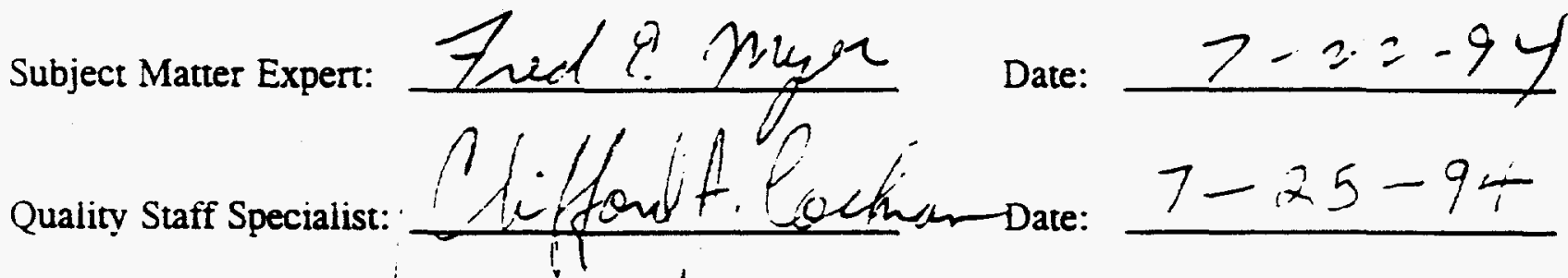

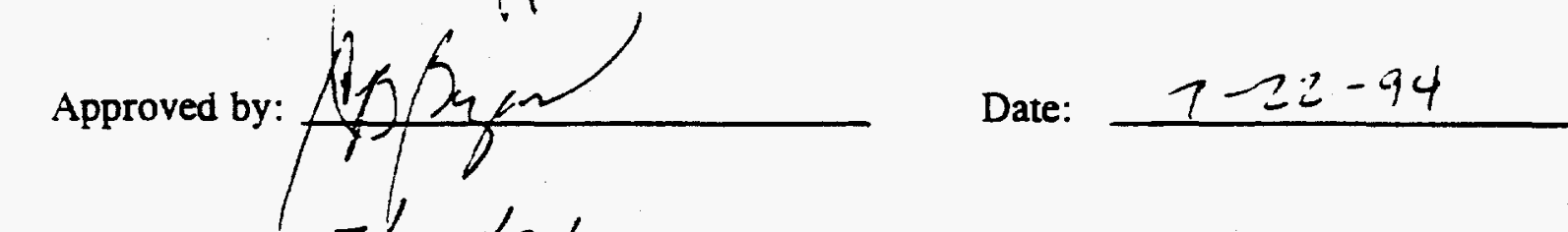

Effective Date:

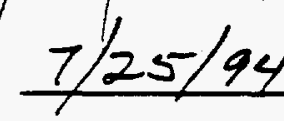

Limits on Effectivity: None

\begin{tabular}{|l|c|c|l|c|c|}
\hline Procedure Type & Yes & No & \multicolumn{1}{|c|}{ Category } & Yes & No \\
\hline In Hand & & $\checkmark$ & Safety System & & $\checkmark$ \\
\hline Upgraded & $\checkmark$ & & Quality-Related & & $\checkmark$ \\
\hline
\end{tabular}

Record of Changes

\begin{tabular}{|l|l|l|l|l||}
\hline Change No. & Affected Pages & $\begin{array}{c}\text { Approval } \\
\text { Signanure }\end{array}$ & $\begin{array}{c}\text { Approval } \\
\text { Date }\end{array}$ & $\begin{array}{c}\text { Expiration } \\
\text { Date }\end{array}$ \\
\hline & & & & \\
\hline & & & & \\
\hline & & & & \\
\hline & & & & \\
\hline
\end{tabular}

Next review required no later than: $7 / 25 / 99$ 
intoritos

BLANK PAGE 
K-25 Site Analytical Services Organization. Sampling and Environmental Support Deparment

\section{CONTENTS}

\section{Page}

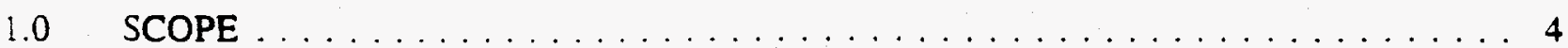

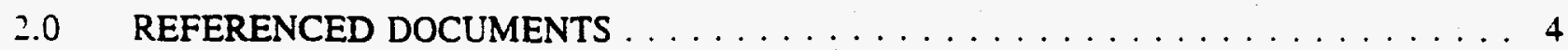

$3.0 \quad$ RESPONSIBILITIES $\ldots \ldots \ldots \ldots \ldots \ldots \ldots \ldots \ldots \ldots \ldots \ldots$

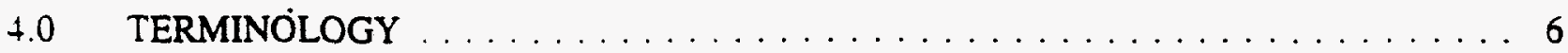

5.0 SUMMARY OF TEST METHODS $\ldots \ldots \ldots \ldots \ldots \ldots \ldots \ldots \ldots \ldots$

$6.0 \quad$ SIGNIFICANCE AND USE $\ldots \ldots \ldots \ldots \ldots \ldots \ldots \ldots \ldots \ldots$

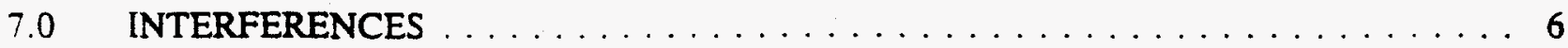

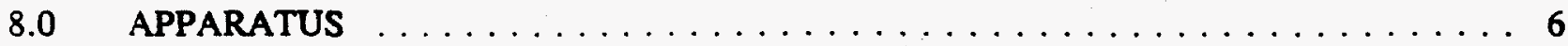

$9.0 \quad$ REAGENTS AND MATERIALS $\ldots \ldots \ldots \ldots \ldots \ldots \ldots \ldots \ldots \ldots$

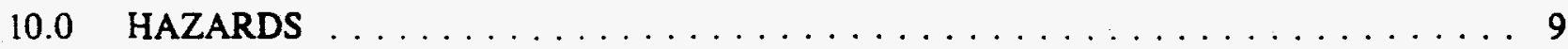

11.0 SAMPLING. SUBSAMPLING. AND TEST SAMPLES $\ldots \ldots \ldots \ldots \ldots \ldots \ldots$

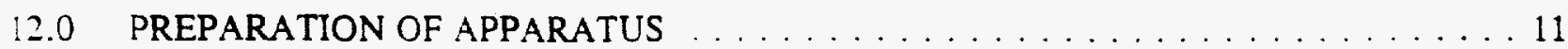

13.0 CALIBRATION AND STANDARDIZATION $\ldots \ldots \ldots \ldots \ldots \ldots \ldots \ldots \ldots$

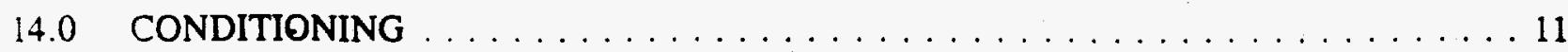

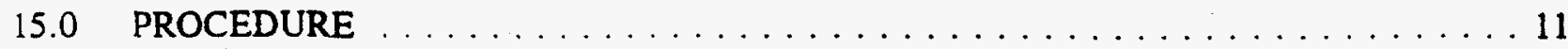

16.0 CALCULATION OR INTERPRETATION OF RESULTS $\ldots \ldots \ldots \ldots \ldots \ldots \ldots$

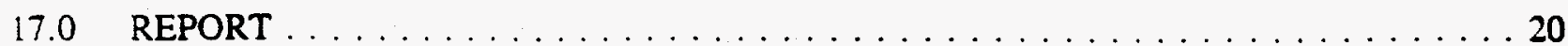

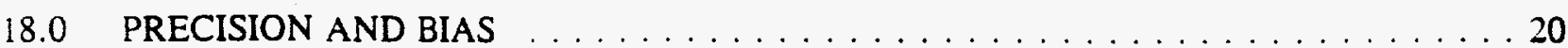

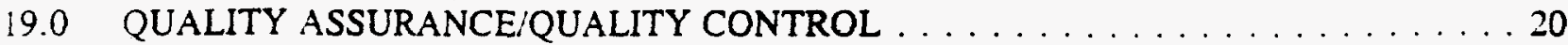

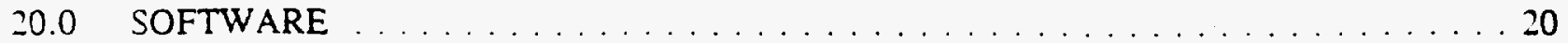




\subsection{SCOPE}

This procedure describes the methods used to sample groundwater wells at the $\mathrm{K}-25$ and $\mathrm{Y}-12$ sites.

\subsection{REFERENCED DOCUMENTS}

2.1 U.S. Environmental Protection Agency, 1987, A Compendium of Superfund Fieid Operations Methods, EPA/540/P-87/001. Washington. D.C.

2.2 U.S. Environmental Protection Agency, 1986. Engineering Support Branch Standard Operating Procedures and Quality Assurance Manual, Region IV, Environmental Services Division. Atlanta, Ga.

2.3 U.S. Department of Energy, 1987. The Environmental Survey Manual, DOE/EH-0053.

2.4 U.S. Environmental Protection Agency, 1986, RCRA Groundwater Monitoring Technical Enforcement Document, OSWER-9950.1.

2.5 Martin Marietta Energy Systems, Inc., 1988, Environmental Surveillance Procedures Quality Control Program, Martin Marietta Energy Systems, ESH/Sub/87/21706/1, Oak Ridge, Tennessee.

2.6 U.S. Department of Transportation, Code FDR 49 Parts $100-177$. Rev. 10-01-92.

\subsection{RESPONSIBILITIES}

\subsection{Sampling Supervisor}

3.1.1 Maintains communications with management and other groups for information that could affect the performance of this procedure.

3.1.2 Ensures that only trained field technicians are assigned to this procedure and that the training is documented.

3.1.3 Ensures that necessary materials and equipment are available and that maintenance is provided.

3.1.4 Schedules resources for sampling in conjunction with the ASO Project Manager.

3.1.5 Provides field sampling technicians with well data information. required sampling parameters, and sampling order as directed by customer.

3.1.6 Interfaces with the customer to obtain scheduling information, containment, access and information about unusual conditions.

3.1.7 Ensures quality in sampling through review of the technician's field sampling logbooks and field data sheets. 
K-25 Site Anaiytical Services Organization. Sampling and Environmental Suppor Deparument

TITLE: Groundwater Sampling
SESD-TP-8204

Rev. 0

Page 5 of 20

3.1.8 Provides field quality assurance through planning and use of established and approved procedures.

3.1.9 Ensures complete chain-of-custody control through review of the chain-ofcustody documents.

3.1.10 Implements corrective actions for field QA deficiencies.

3.1.11 Provides notification of unusual field conditions to ASO Project Manager and the Groundwater Protection Program Manager (GPPM) at each site.

3.1.12 Maintains control of this procedure and its controlled copies.

\subsection{Sampling Technician}

3.2.1 Performs groundwater sampling according to this procedure only after receiving appropriate training.

3.2.2 Decontaminates and maintains sampling equipment as required by this procecture.

3.2.3 Legibly documents all field measurements, field conditions, and samples as required by this procedure and ensures that all field documentation is complete.

3.2.4 Takes samples as required by approved methodology and maintains sample quality at all times.

3.2.5 Properly preserves all samples according to EPA protocol as defined in the current and approved S/A Plan.

3.2.6 Delivers all samples to the K-25 ACD Sample Management Group custodian or to the contract laboratory under documented chain-of-custody within the required holding times.

3.2.7 Ensures a complete chain-of-custody documentation on all samples.

3.2.8 Maintains a clean and orderly working area in the truck or lab.

3.2.9 Conducts sampling operations in a safe, efficient manner so as to not injure themselves or others.

3.2.10 Maintains field copies of the Environmental Surveillance Procedures. SOPs, and the following items from the current S/A Plan: all addendas. quarterly sampling schedules. bottle lists. site maps, and well depths. 
SESD-TP-8204

Rev. 0

Page 6 of 20
K-25 Site Anaiytical Services Organization. Sampling and Environmental Support Deparament

TITLE: Groundwater Sampling

\subsection{TERMINOLOGY}

Does not apply

\subsection{SUMMARY OF TEST METHODS}

5.1 Groundwater samples are collected after an appropriate well purge by using a bailer or pump. If required, the purge water from the wells is transferred into collection containers and is transported to the plant for appropriate water trearment. Field determinations which include $\mathrm{pH}$, specific conductance, oxidation-reduction potential, dissolved oxygen, and temperature are obtained on an initial sample from the well. Additional measurements of the same type are taken for each well volume purged and after the final purge volume. All samples are preserved in the field according to EPA protocol as defined in the current and approved Sampiing and Analysis (S/A) Plan.

5.2 All samples are then delivered to the K-25 Analytical Chemistry Deparment (ACD), Sample Management Group (SMG), or to a contract laboratory.

\subsection{SIGNIFICANCE AND USE}

6.1 This method is applicable to the sampling of groundwater wells at K-25 and Y-12 sites only.

6.2 This procedure does not replace manufacturer instrument operation manuals. The purpose of the procedure is to supplement that information and to provide field sampling technicians with additional sampling instructions.

\subsection{INTERFERENCES}

Does not apply

\subsection{APPARATUS}

8.1 Safety equipment: Company issued clothing (including cold weather apparel. rain suits), pagers and cellular phones, steel-toed safety shoes, safery glasses with side shields, rubber gloves, if required Tyvek coveralls or rubber aprons, rubber overshoes, hard hat, cotton gloves. respirators, fire extinguishers, insect repellant, and insulated water coolers.

8.2 Consumables: Ground cloth (polyethylene), $\mathrm{pH}$ paper, fluorocarbon resin-coated wire, nylon cord, single strand stainless wire, tape, gloves, plastic bags, paper towels, wash bottles, and blue or water ice.

8.3 Field data sheets, chain-of-custody forms, and equipment calibration record forms; chainof-custody seals, labeis, indelible black ink pens, indelible marking pens, and electronic calculator. 
K-25 Site Analytical Services Organization. Sampling and Environmental Support Deparment

TITLE: Groundwater Sampling

8.4 Measuring tape and an electronic water level indicator (for measuring depth to water in the well).

8.5 Compressed gas cylinder or air compressor with associated regulators and high pressure air lines as necessary to operate the pump.

8.6 Bottom loading bailer of teflon or equivalent construction with a closed top, well sampling pump lines of sufficient length to reach the screened portion of the well. and if required controller boxes with associated air hoses and connections to operate the dedicated sampling pumps.

8.7 At the start of each day all field analytical equipment is calibrated in accordance with the procedures listed in Sections 8.7.1 through 8.7.5 of this procedure. Results are recorded in calibration log books with the sheet number recorded on the field data sheet. All temperanure meters are calibrated and verified against a National Institute of Standards certified thermometer, which is calibrated annually by the K-25 Metrology, Testing and Equipmem Laboratory (MT\&E). If an instrument is thought to be out of calibration; while in the field, the rechnician must recalibrate the instrument. If the instrument is found to be out of calibration: the supervisor must be contacted; so the customer and program management can determine if the previous data is valid: of if a resample is required. If an instrument is no calibrated on the proper schectule (overdue), the instrument will be treated as out of calibration and then will be tagged with a " Do Not Operate" tag. Immediate action should be taken to ensure the instrument is recalibrated.

\subsubsection{Temperature Meter Operation and Verification, SESD-TP-8005.R0, 11-29-93}

8.7.2 Ph Meter Operation and Calibration, SESD-TP-8007.R0, 11-19-93

8.7.3 Dissolved Oxygen Meter Operation \& Calibration, SESD-TP-8008.R0, 11-29-93

8.7.4 Redox Meter Operation and Calibration, SESD-TP-8201.R0, 11-29-93

\subsubsection{Conductivity Meter Operation and Calibration, SESD-TP-8202.R0, 11-29-93}

NOTE: Do not use balance if certification is expired.

8.8 Laboratory Analytical Balance must be certified annually by the K-25 Site MT\&E program and checked by technician each time of use to standard weight and recorded in reagent log book. Balance certification date must also be tracked in reagent log book.

8.9 Sample containers of assorted sizes and types as required by the analyses specified for each well as defined in the current and approved S/A Plan.

8.10 Filtration apparans equipped with a 0.45 or 0.10 micron membrane filter for filtering the dissolved metais sample. 
SESD-TP-8204

Rev. 0

Page 8 of 20
K-25 Site Analytical Services Organization. Sampling and Environmental Support Deparunent

TITLE: Groundwater Sampling

\subsection{APPARATUS (Continued)}

8.11 Insulated ice chest containing 8 lbs. of ice or 8 pint size packs of "Blue Ice" or an equivalent amount for sample preservation.

8.12 Hunter/Keck - Model KIR-89 portable product level and thickness measuring device for inorganic layers, and the thickness of each layer in groundwater monitoring wells.

\subsection{Toois and Tool Box.}

8.14 Required Procedure Books and Training Manuals.

8.15 DOT approved packaging, labeis, and shipping papers.

\subsection{REAGENTS AND MATERIALS}

9.1 ASTM Type II distilled deionized water. A carboy of the water will be collected and stored in K-1004-A, Room 18, with a conductivity reading recorded each time the carboy is filled and recorded in a reagent log book.

9.2 A Chemical Inventory Sheet (HMIS) is required for the Groundwater Sampling Group and is to be located in K-1004-A, Room 18, K-1004-H Dock, and each of the sampling vehicles. An "*" indicates those materials maintained in the sampling vehicle. A " $\dagger$ " denotes a DOT shipping label required for transfer.

NOTE: Visually inspect preservatives for discoloration or degradation before use to ensure reagent quality. Replace dispensing botties January 1 and July 1 of each year.

NOTE: Replace standard solutions in each instrument box at the beginning of each quarter.

9.2.1

$\mathrm{H}_{2} \mathrm{SO}_{4}$ - Sulfuric Acid (96.4\%)

9.2.2 $\mathrm{HCl}-$ Hydrochloric Acid $(36.5-38.0 \%)$

9.2.3 $\mathrm{NaOH}$ - Sodium Hydroxide (50.0\%)

9.2.4 $\mathrm{HNO}_{2}-$ Nitric Acid $(69.0-71.0 \%)$

9.2.5 Nitrogen, Compressed

9.2.6 Ascorbic Acid
UN 1830 PGII LID-QTY *†

UN 1789 PGII LTD-QTY *+

UN 1824 PGII LTD-QTY *+

UN 2031 PGII Corrosive *†

UN 1066 Nonflammable Gas labels applied *† 
K-25 Site Analytical Services Organization. Sampling and Environmental Support Deparment

\subsubsection{Ascorbic Acid \\ 9.2.8 Bolt Wasp \& Hornet Killer II * \\ 9.2.9 Buffer solutions 4.7, and $10^{*}$}

9.2.10 Formula 409

9:2.11 Hach Chlorine Equivalent Standard Solution

9.2.12 Isopropyl Alcohol

9.2.13 Lava Soap

9.2.14 Liqui-Nox Detergent

9.2.15 Micro Soap

9.2.16 Potassium chloride

9.2.17 Potassium ferricyanide

9.2.18 Potassium ferrocyanide

9.2.19 Sodium Calcium Hydrate (Soda Lime)

9.2.20 ${ }^{\circ} \quad$ Sodium Sulfite *

9.2.21 Softcide Hand Wash

9.2.22 Zinc Acetate

9.2.23 $0.01 \mathrm{~N} \mathrm{KCl}$ standard solution. Each lot prepared and recorded in reagent log book.*

9.2.24 Zobell standard solution. Each lot prepared and recorded in reagent log book. *

9.2.25 Lead free gasoline *

9.2.26 10W-30W Motor Oil *

\subsection{HAZARDS}

10.1 Ensure that at least two persons are present during well sampling operations.

10.2 Conduct no sampling operations during thunderstorms. 
SESD-TP-8204

Rev. 0

Page 10 of 20
K-25 Site Analytical Services Organization. Sampling and Environmental Support Deparment

TITLE: Groundwater Sampling

\subsection{HAZARDS (Continued)}

10.3 Have some form of communication in the field for use during sampling operations.

10.4 Obtain permission to enter sampling areas located above the firing range and ensure that the firing range is clear before starting sampling operations.

10.5 On weekends or overtime hours. contact Plant Shift Superintendent at Y-12 and K-25 to give a record of sampling location.

10.6 Carry along an adequate supply of ASTM Type II distilled deionized reagent grade water for use in equipment rinses and cleaning.

10.7 Use adequate protective clothing during cold weather sampling operations. For hot weather sampling, carry an adequate supply of drinking water. insect repellent and wasp spray. For comfort. make sure air-conditioning in trucks is operational.

10.8 Recognize and be aware of hazardous flora and fauna.

10.9 Use the proper method for moving and lifting heavy equipment.

NOTE: Always remove the regulator and replace the cylinder cap before operating the vehicle.

10.10 Use proper technique for the safe operation of well pumps, portable gasoline-engine driven electric generators. portable air compressors. and high pressure compressed gas cylinders and reguiators.

YOTE: Refer to Martin Mariena Energy Systems Safery and Health Plan (Y-12 procedure, 70 series for environmental health and safety applications).

10.11 Store, transport, and use hazardous and flammable reagents in the manner consistent with the guidance provided in each chemical's Material Safety Data Sheet (MSDS) and DOT regulations. This information can be found in Sections 8.14 and 9.0 of this procedure

10.12 Always wear steel-toed shoes, company issued clothing, gloves, and safety glasses while performing sampling operations.

10.13 As per the requirements of ESP-800, have all samples taken from $\mathrm{K}-25$ and $\mathrm{Y}-12$ groundwater weils, surveyed and green ragged by Health Physics before shipment to an offsite contract laboratory. Retain a copy of green tags for records. 
K-25 Site Analytical Services Organization. Sampling and Environmental

Suppor Deparment .

Rev. 0

TITLE: Groundwater Sampling

Page 11 of 20

\subsection{SAMPLING. SUBSAMPLING, AND TEST SAMPLES}

Does not apply

\subsection{PREPARATION OF APPARATUS}

Does not apply

\subsection{CALIBRATION AND STANDARDIZATION}

Calibrated instruments are used to take field measurements at the well sites as per Section 8.7.

\subsection{CONDITIONING}

Does not appiy

\subsection{PROCEDURE}

\subsection{Preliminary Preparations}

15.1.1 Don the necessary safety equipment.

15.1.2 Clean all pumps, bailers, water level indicators, and other down-hole equipment.

15.1.3 Identify the well(s) to be sampied.

15.1.4 Obtain the required information about the specific well(s) to be sampled.

1. Well location

2. Depth of the weil

3. Diameter of the well casing

4. Method(s) to be used to sample the well

15.1.5 Check the field instrumentation as per the Steps of Sections 8.7 and 13.0. Record the required information on the equipment calibration data form.

15.1.6 Prepare the required trip blanks according to the Sampling and Analysis Plan requirements and SESD-TP-8203.R0.

15.1.7 Load the vehicle with the required equipment and supplies and secure it for transportation of supplies to the field. 
SESD-TP-8204

Rev. 0

Page 12 of 20
K-25 Site Analytical Services Organization. Sampling and Environmental Support Deparunent

TITLE: Groundwater Sampiing

\subsection{Sampling}

15.2.1 Record the well number. site, date, weather conditions, arrival time, and other well specific information on the field data sheet. Examples would include problems with site access. equipment malfunctions, well obstructions, strange odors, names of visitors, etc.

NOTE: When the sampling equipment must be removed from the tailgate area. use plastic trays or groundcover to prevent possible contamination. Discard the plastic sheeting after use along with any other disposable items.

15.2.2 Keep all equipment in the truck bed during sampling.

15.2.3 Unlock and open the well: note the condition of the well.

15.2.4 Don rubber gloves.

NOTE: Change rubber gloves between sampling wells.

15.2.5 Remove any dust or corrosion from around the well head using a non-metal bound brush.

15.2.6 Sample the air in the well head for organic vapors if required by the current and approved S/A Plan.

15.2.7 Note the diameter of the well bore and locate the reference mark at the top of the well casing.

15.2.8 Check the battery on the water level indicator.

15.2.9 Lower the electronic water level indicator probe into the well, making sure that the cord on the probe does not scrape the sides of the well casing.

NOTE: Accurate well depth data will be provided by site GWPP Manager's office annually.

15.2.10 Measure the depth to water from the established reference mark at the top of the innermost well casing.

15.2.11 Stop lowering the probe when the buzzer sounds.

15.2.12 Pull up on the probe until the buzzer no longer sounds.

15.2.13 Lower the probe again slowiy. 
K-25 Site Anaiytical Services Organization. Sampling and Environmental Support Deparument:

TITLE: Groundwater Sampling

SESD-TP-8204

Rev. 0

Page 13 of 20

15.2.14 Stop at the instant the buzzer sounds.

15.2.15 Hold the cord to the side of the casing at the location of the reference mark.

15.2.16 Mark the cord with your thumb where it touches the reference mark.

15.2.17 Use a measuring tape to determine the total depth from the top of the casing to the water if the cord does not have measurement graduations.

15.2.18 Record the value in the field data logbook to the nearest 0.01 foot as per ESP 302-1.

15.2.19 Determine the depth to water two additional times to verify correct measurement.

15.2.20 Record the additional values as described in steps 15.2.9 through 15.2.18.

15.2.21 Average the three depth to water measurements and record the average value in the field data logbook.

15.2.22 Remove the water level indicator from the well.

NOTE: If required by the current and approved S/A Plan, collect the rinse water from this cleaning procedure in an appropriate containment vessel, and properly dispose of the water at the wastewater treatment system at the plant.

15.2.23 Rinse the probe and any portion of the cable that contacted the well water with ASTM Type II distilled deionized reagent water.

15.2.24 Wipe the probe and cabling with paper towels.

15.2.25 Place the indicator in a clean plastic bag to prevent contamination during transport.

15.2.26 Determine the height of the water column by subtracting the depth to the water from the total weil depth.

15.2.27 Calculate the volume of water in the well casing using the appropriate formula given below. 


\subsection{PROCEDURE (Continued)}

$$
\begin{aligned}
& 2^{\prime \prime} \text { well: } 0.1632 \text { gallft } x \text { (height of water column) }=\text { gallons } \\
& 4^{\prime \prime} \text { well: } 0.6528 \text { gallft } x \text { (height of water column) = gallons } \\
& 6 " \text { well: } 1.4688 \text { gallft } x \text { (height of water column) = gallons }
\end{aligned}
$$

NOTE: Use a bailer that has a diameter of less than 2 " on ail 2 " well casings.

15.2.28 Obtain an initial well water sample using either a bailer or a pump.

1. Attach the bailer to a fluorocarbon resin-coated wire, nylon cord, or single strand stainless steel wire.

2. Lower the bailer siowly to the mid-point of the screened or open portion of the well.

VOTE: The air can be connected prior to lowering the pump into well to insure that the pump head is working properiy.

3. Lower the pump into the well casing to the air/water interface.

4. Attach an air line and source of compressed air to the pump.

NOTE: If required by the currently approved S/A Plan, collect the water from these analyses in an appropriate containment vessel. and properiy dispose of the water at the plant wastewater treatment system.

5. Withdraw sufficient water from the well to perform the required "initial" determinations as specified in Step 15.2.30.4.

NOTE: If required by the currenty approved S/A Plan, collect the well purging water in an appropriate containment vessel. and properiy dispose of the water at the plant wastewater treatment system. 
K-25 Site Anaiytical Services Organization. Sampling and Environmental

Support Deparment

SESD-TP-8204

Rev. 0

TITLE: Groundwater Sampling

Page 15 of 20

15.2.29 Purge the well of the required number of volumes of water using a bailer (per ESP 302-3), or a gas driven Bennett Pump (per ESP 302-4), or using a Bladder pump (Well Wizard) (per ESP 302-5). Wells are required to be purged until at least three volumes of water are removed

NOTE: When evacuaring low-yield wells( that are incapable of yielding three casing.volumes), evacuate the well to dryness only once. A well is dry when the pump thas been lowered to one foot from. the bottom of the well and the water does not continue to evacuate.

1. Remove the required volumes of water or bail until the well goes dry if using a bailer.

2. Determine the punp flow tate in the fiota by timing the rate at which a one gallon container can be filled by the pump if using a pump.

3. Record the information on the field data sheet.

4. Calculate the required purge time based on this field determined pumping rate.

5. Purge the well a minimum of three well volumes of water or umil the well goes dry.

NOTE: The purge rate of the Bennett Pump and Bladder pump is usually less than two gailons per minute.

6. Purge the well at a rate such that the recharge water does not become agitated or cascades back into the well.

7. Record the purge start time and the purge end time on the field data sheet.

15.2.30 Allow the water in the well to recover.

NOTE: Whenever full recovery exceeds two hours, extract the sample as soon as sufficient volume is available for a sample for each parameter. 
SESD-TP-8204

Rev. 0

Page 16 of 20
K-25 Site Analytical Services Organuzation. Sampiing and Environmental Support Department

TITLE: Groundwater Sampiing

\subsection{PROCEDURE (Continued)}

1. Recharge volume or time as directed by the current and approved S/A Plan.

2. Allow sufficient time for the well to recover and stabilize before obtaining samples if a well is bailed dry or pumped dry.

\subsubsection{Sample the water in the well.}

NOTE: Collect all samples at one time if sufficient water is present.

VOTE: Certain sites may require additionai parameters (samples) at a site, such as COD. Cyanide. TPH. tritium, gamma spectrum. Ammonia, and Nitrite. See Bottle List for sampling sequence and additional parameters.

1. Obtain samples of the well water for the field determinations.

2. Obtain and analyze samples for $\mathrm{pH}$ as per ESP 307-2, specific conductance, temperature as per ESP 307-1, oxidation-reduction potential as per ESP 307-5, and dissolved oxygen as per ESP 307-3.

3. Obtain separate analyses for each parameter at eveniy spaced intervals during the purge cycle.

NOTE: When sampling VOA. TOX, and TOC from a dedicated bladder pump, cut the purge rate down to approximately $100 \mathrm{ml} / \mathrm{min}$. or as low as the pump will allow. When sampling VOA. TOX. and TOC with a bailer. lower the bailer slowly into the sample interval of the well to prevent loss of volatile components.

4. Collect the required samples for analysis in the laboratory.

- Collect and obtain sample per ESP 302-3 when using a bailer, per ESP 302-4 when using a Bennett pump, and per ESP 302-5 when using a bladder pump.

- Collect samples that may be affected by the loss of volatile components first, i.e.. VOA, TOX, TOC.

- Collect VOA, TOX. and TOC samples using a bailer or Bladder pump.

- Transfer the samples slowly, with minimum agitation and aeration.

- Collect these sampies with zero headspace and check to ensure the absence of air bubbles.

- Collect all VOAs. then all TOCs. then all the metals. etc. Do not pull one complete set of samples and then start to pull another set. 
K-25 Site Analytical Services Organization. Sampling and Environmental Support Deparmen

- Collect samples for dissolved metais using an in-line filter while sampling with a Bennet pump or Bladder pump.

- If dissolved metal samples are being collected using a bailer, the unfiltered samples are returned to the laboratory for filtering and preservarion.

- Collect the balance of the required samples for the particular site in the following order:

\section{Base-Neutral-Acid Extractables \\ Herbicides \\ Pesticides \\ Phenols \\ Turbidity}

Anions (Iodine: Carbonate-Bicarbonate. Nitrate-Nitrogen)

$\mathrm{pH}$ and conductivity

Total coliform bacteria

Total suspended solids

Total dissolved solids

Carbonate/Bicarbonate

Kjeldahl Nitrogen

Metais, total and dissolved

Gross alpha and beta

Total Radium

Uranium 235

- Exceptions to this sampling order include the following:

(A) The Bennett pump is used for purging and sampling groundwater wells locared on the Y-12 and K-25 Plant sites. In these situations, the Bennett pump may be used to sample all non-volatile sample fractions first. Then remove the pump and collect the volatile fractions using a bailer. Note any exceprions to this order of collection in the field data sheets.

- Record the sample types taken on the fieid data sheet and the times when remaining samples are collected.

15.2.32 Obtain like samples one after another if duplicate samples are to be taken..

15.2.33 Add the required preservatives to the samples as they are obtained, if the preservatives have not already been added to the sample containers.

NOTE: Check the $\mathrm{pH}$ of all samples except the VOA samples in the $40 \mathrm{~mL}$ viais. 


\subsection{PROCEDURE (Continued)}

NOTE: Do not insert the pH paper to the sample. To ensure the proper amount of preservative was added. check the $\mathrm{pH}$ of the preserved sample with narrow range $\mathrm{pH}$ paper by pouring a small amount of the sampie over the pH paper.

15.2.34 Adjust the $\mathrm{pH}$ of a sample to $<2.0$ by adding the appropriate acid for samples that require $\mathrm{pH}$ adjustment.

15.2.35 Document that the $\mathrm{pH}$ adjustment was made by checking the appropriate blank on the field data sheet.

15.2.36 Ensure that all samples are labeled properiy with well number. date. time, sampler's name, any other pertinent information. and anaiysis.

NOTE: If required by the currently approved S/A Plan, collect the rinse water from this cleaning procedures in an appropriate containment vessel, and properly dispose of the water at the wastewater treatment system at the piant.

15.2.37 Wash the outside of the sample containers with distilled water.

15.2.38 Place the samples in a cooler containing blue or water ice.

15.2.39 Obtain any blank samples for the well as required by the Sampling and Analysis Plan.

15.2.40 Return the bailer to the lab for decontamination after each well's sampling is completed.

NOTE: If this is the last well for a given site. collect all equipment rinsate sample. Check the current S/A Plan for the analytical parameters required.

1. Rinse the interior and exterior with a non-phosphate detergent.

2 Rinse all detergent from the equipment with ASTM Type II distilled deionized reagent grade water.

3. Rinse the equipment a second time with ASTM Type II distilled deionized reagent grade water.

4. Rinse the bailers with a ten percent nitric acid solution. then with ASTM Type II distilled deionized reagent grade water.

5. Wipe down the equipment with paper toweling.

6. Wrap rully assembled bailer in aiuminum foil for lab to field transport. 
Field clean the Bennett pumps after sampling each well in a given site as described below.

1. Rinse the entire length of the pump head with water. then pump one to two gallons of a non-phosphate detergent water through the system.

2. Rinse all detergent from the pump by flushing the entire length of the pump head with one to two gallons of ASTM Type II distilled deionized reagent grade water.

3. Rinse the equipment a second time with an additional one to two gallons of ASTM Type II distilled deionized reagent grade water.

4. Seal the pump head in a clean plastic bag and proceed to the next well site for sampling.

15,2.42 Decontaminate the Bennett pump after sampling the site (one to ten wells) by taking the pump to the lab area where a steam supply is available.

1. Steam clean the pump head and the entire length of tubing.

2. Bring pump into lab to perform rinse.

NOTE: To minimize waste, use approximately 0.7 gallons of solution for the 125 foot pump; approximately 1.4 gallons for the 250 foot pump; and approximately 2.8 gallons for the 500 foot pump.

3. Run a rinse solution consisting of $10 \%$ Nitric acid and water in lab ensuring that entire tubing bundle of the pump is fully filled with the solution.

4. Collect the Nitric acid waste in 55-gallon Acid Waste Drum.

5. Run a 30 minute tap water rinse to thoroughly remove the Nitric acid and any remaining residue.

6. Flush the tubing and pump with two tubing volumes of ASTM Type II deionized, distilled reagent grade water.

7. Wipe down pump head with paper towel and wrap in aluminum foil for lab to field transport.

8. Collect an equipment rinse blank at the frequency and for the parameters specified in the current and approved S/A Plan. 


\subsection{PROCEDURE (Continued)}

15.2.43 Replace the cover on the well and secure the well with the lock.

15.2.44 Renurn the sampling equipment to the vehicle and secure the equipment for :ansport back to the plant or to the next weil site.

15.2.45 Clean up the well sampling site.

15.2.46 Enter the departure time in the field data sheet.

15.2.47 Report any maintenance problems at the well site (such as replacing hasps, locks, concrete pads. protective posts. obstructions inside of the weil casings, well access, etc.) to the appropriate GPPM by means of a Well Maintenance Request Form.

15.2.48 Sign the field data sheet.

\subsection{CALCULATION OR INTERPRETATION OF RESULTS}

The volume of water in a well casing is calculated using the formulas listed in step 15.2.26. The purge time and pump flow rate is calculated according to the step 15.2.28.2.

\subsection{REPORT}

All sampling data coilected from a weil site is recorded on the field data sheet and in the field data logbook.

\subsection{PRECISION AND BIAS}

Does not apply

\subsection{QUALITY ASSURANCE/QUALITY CONTROL}

19.1 Well sampling frequency and the required analyses are determined by the well location and the current Sampling and Anaiysis Plan.

19.2 This procedure will be performed in accordance with Martin Marietta Energy Systems regulations and state and federal laws.

\subsection{SOFTWARE}

Does not apply 


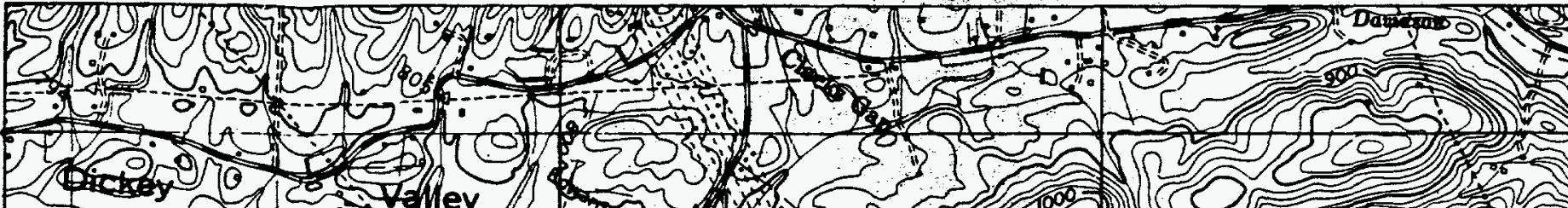

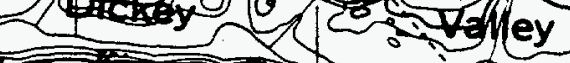
定

(2)
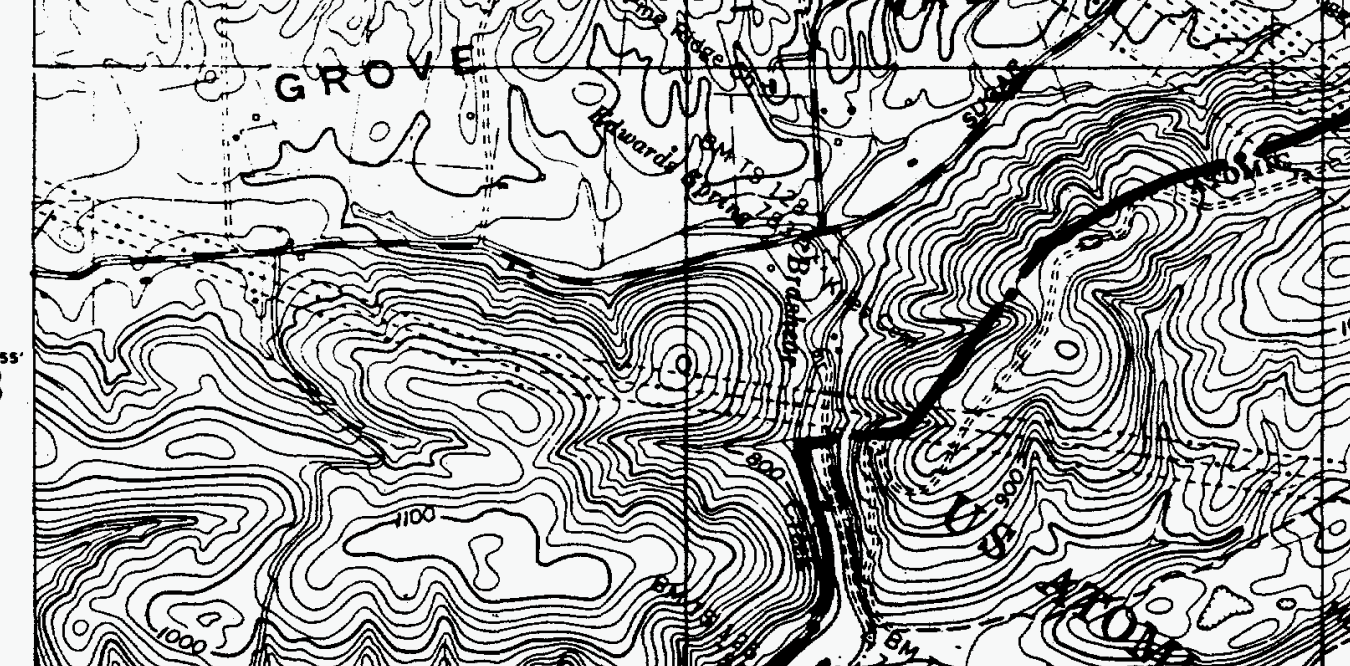

$0.000 \sim 2010$
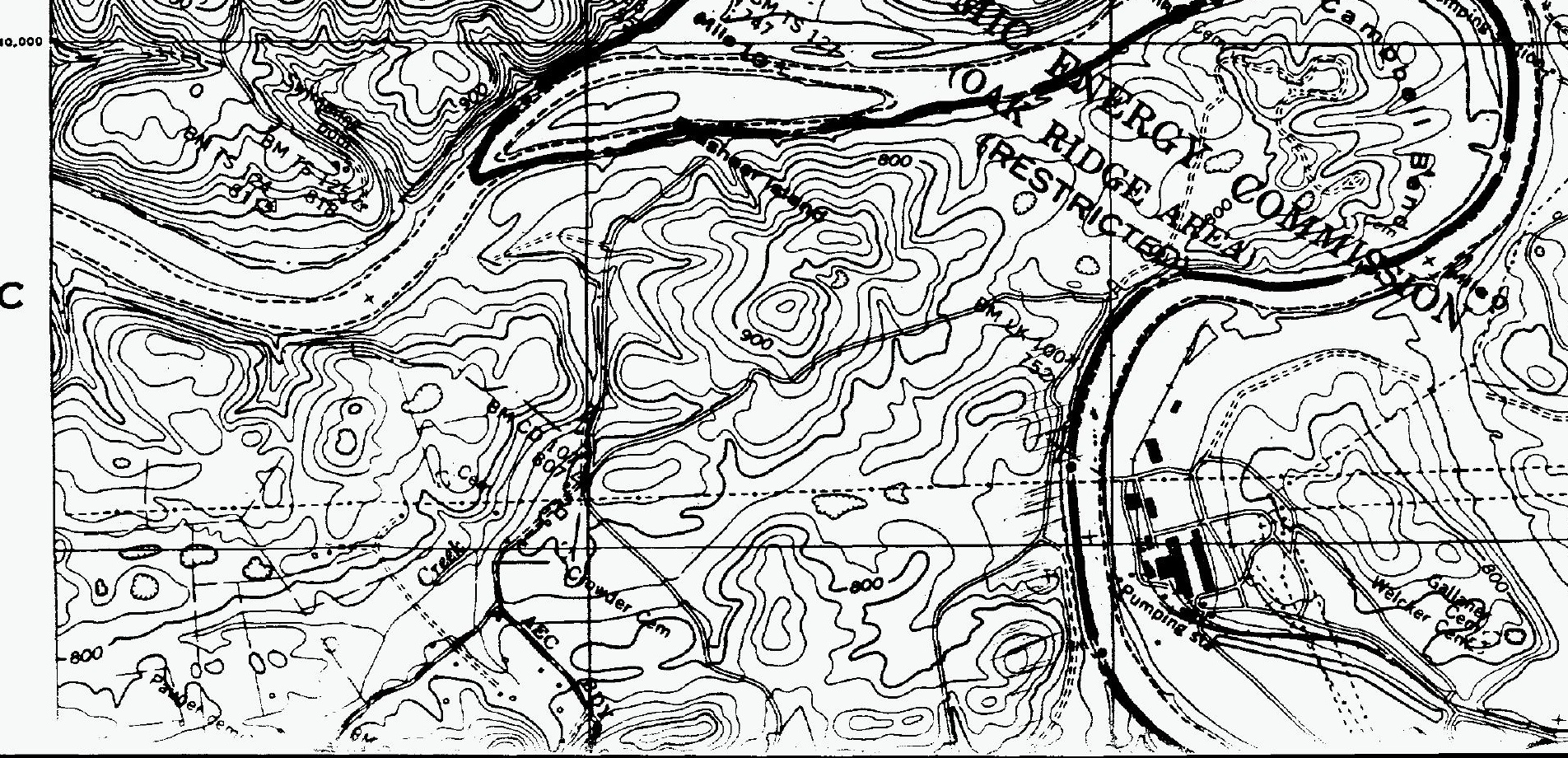

C 
3

4

5

6
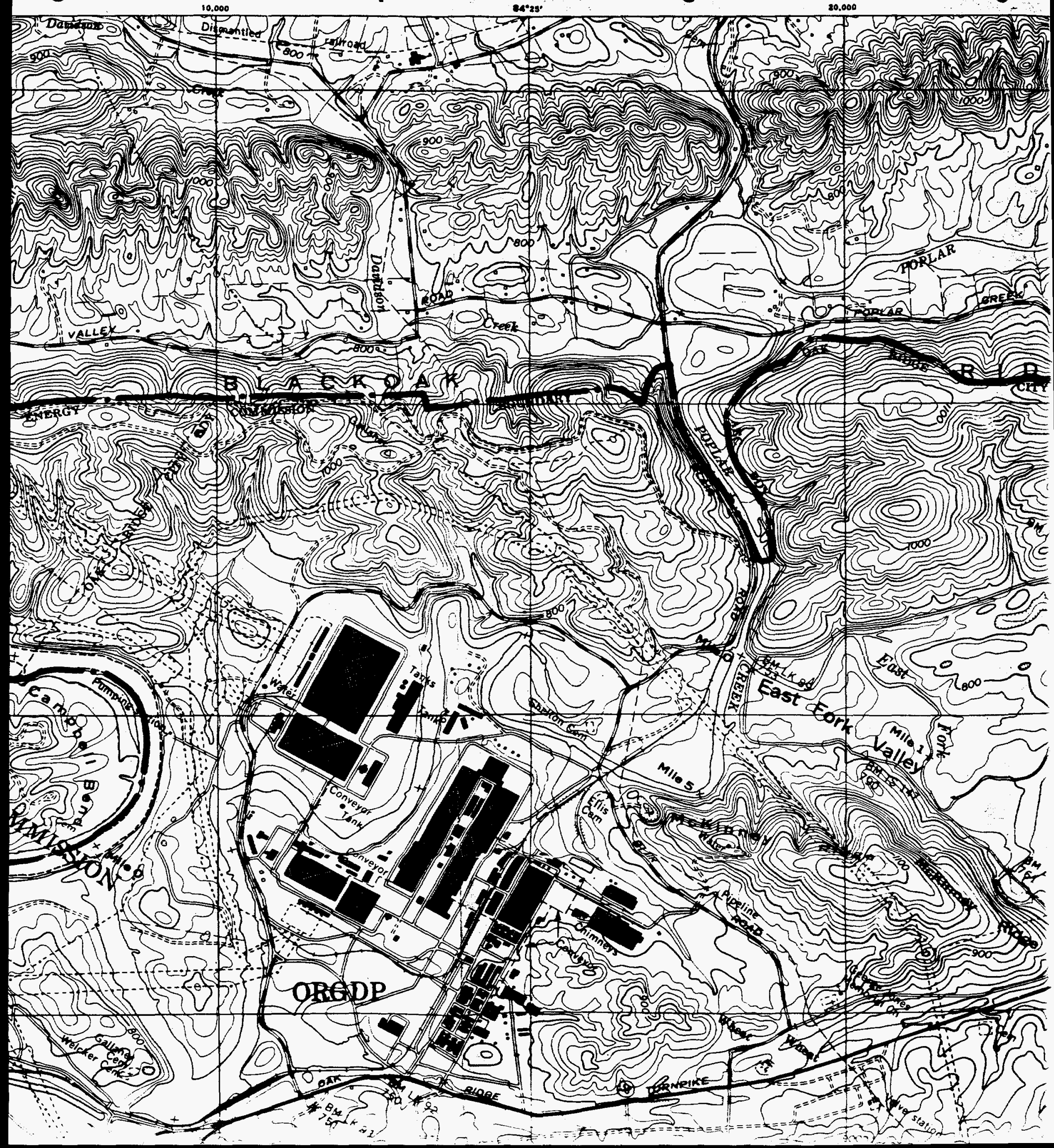
5.5. (2)

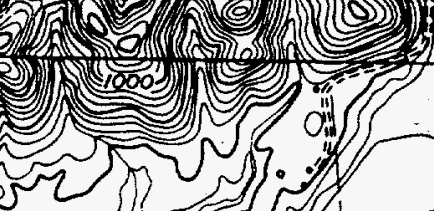

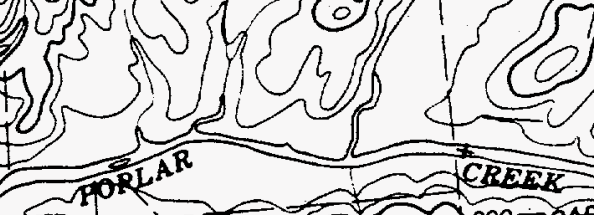

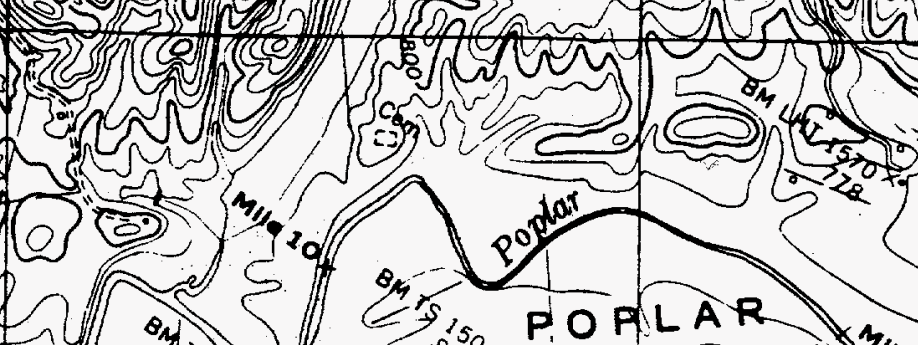

QREE.K

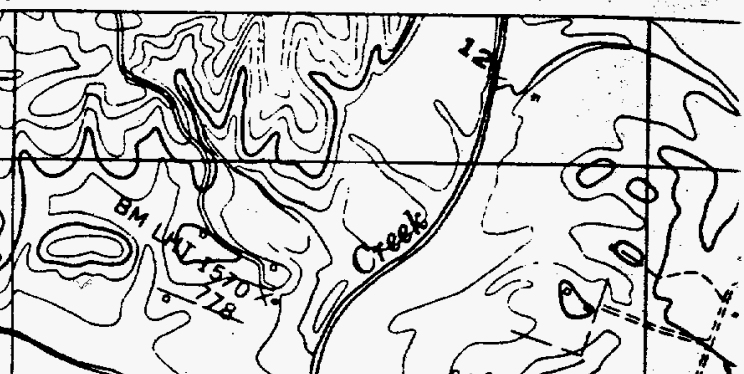

$60)$

orian

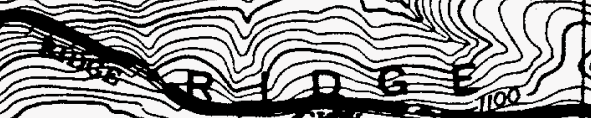

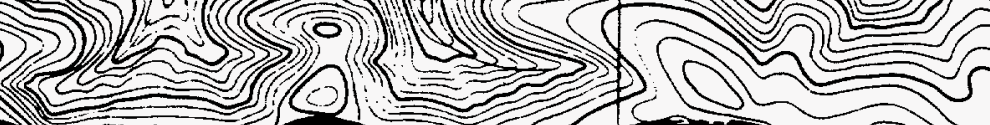

(2) 3 )

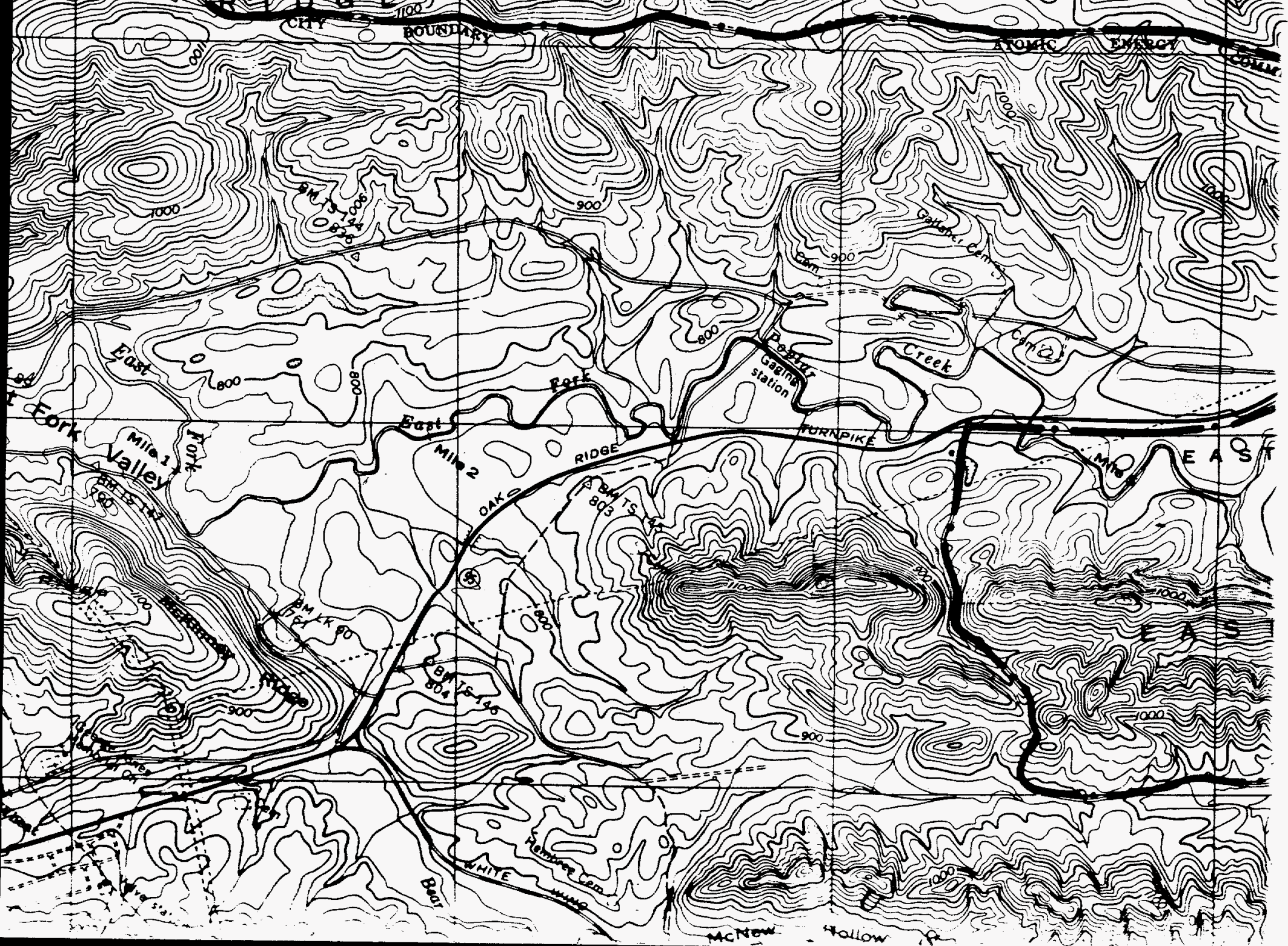


OAK RIDGE AREA

OAK RIDGE, TENNESSEE 
1)

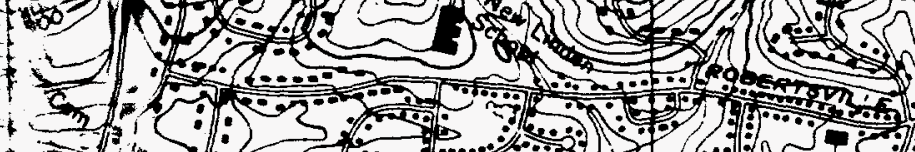

Nisis

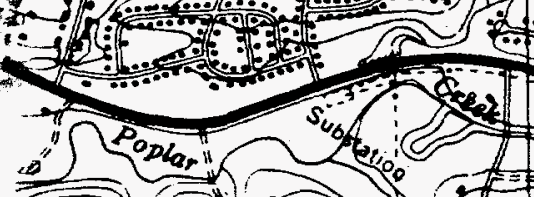

S)
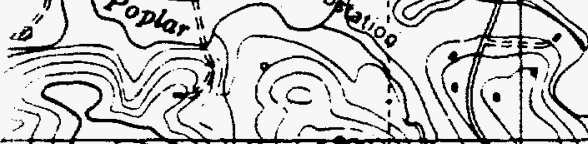

(S)

1 .

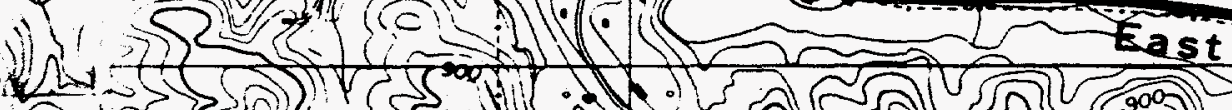

ล

?

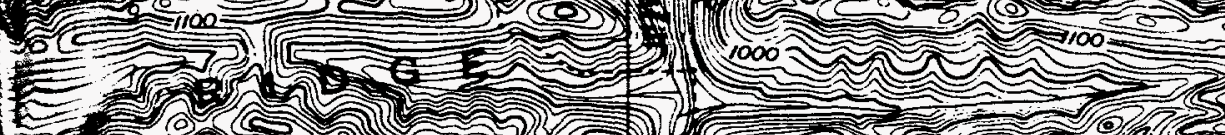
,

(c)

a $\rightarrow 5$ 10 (cos) (6)

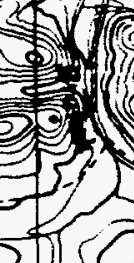




\section{4}

15

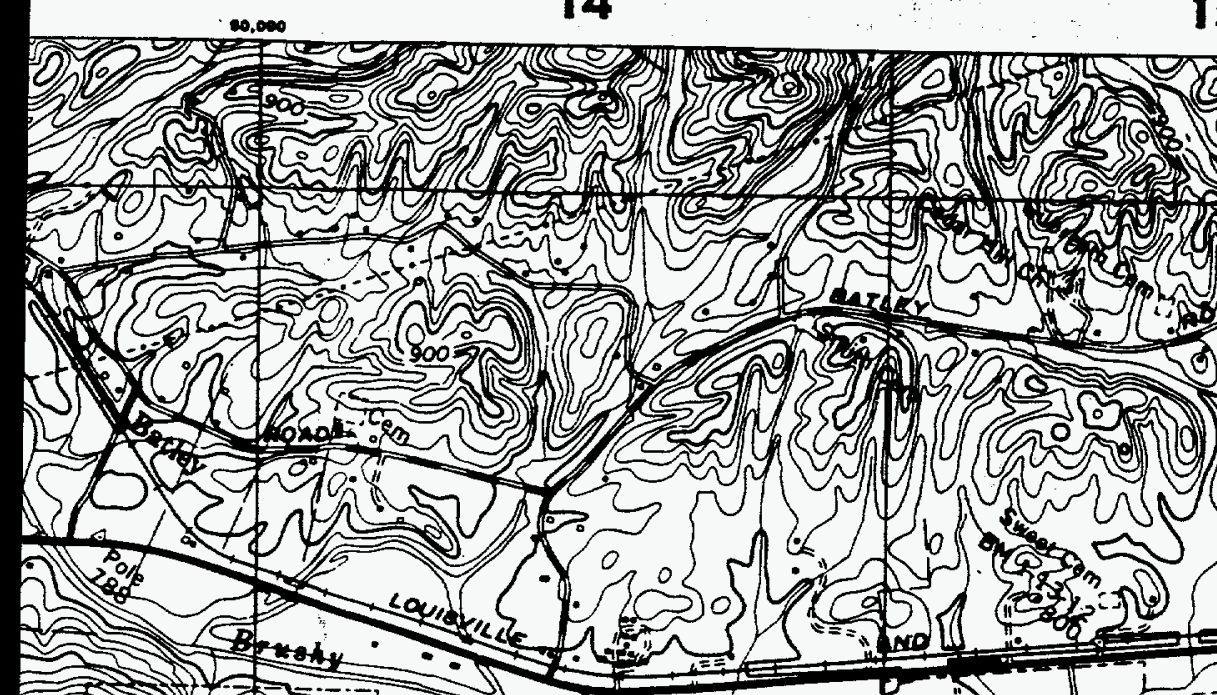

5 . 16 16 (1). (c) : (5) (1) (1) (1) (2) (1000

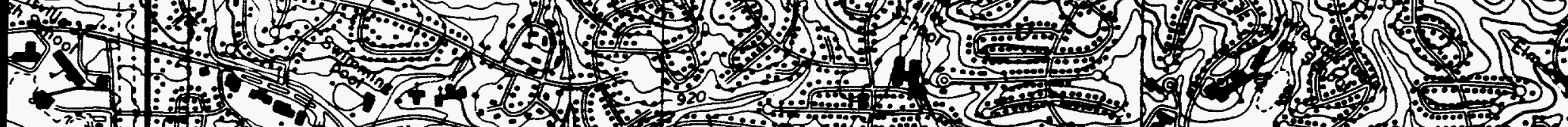
6. (1) 


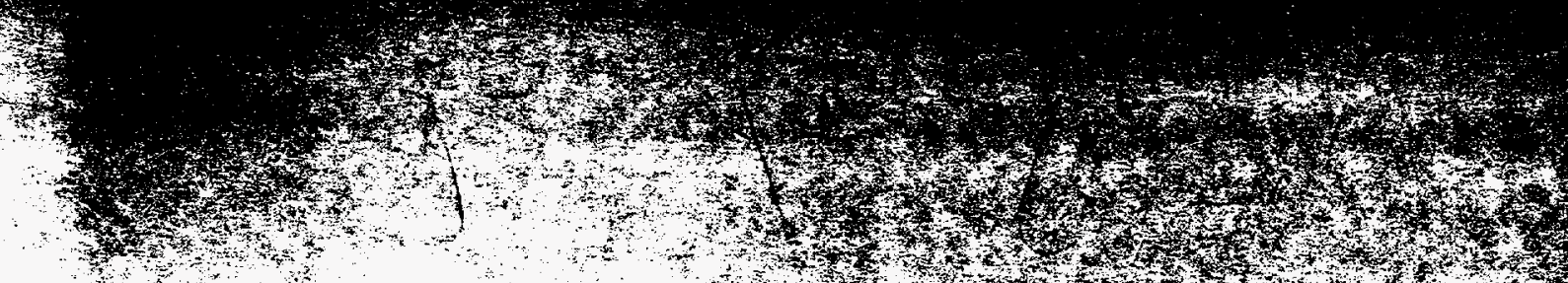

17

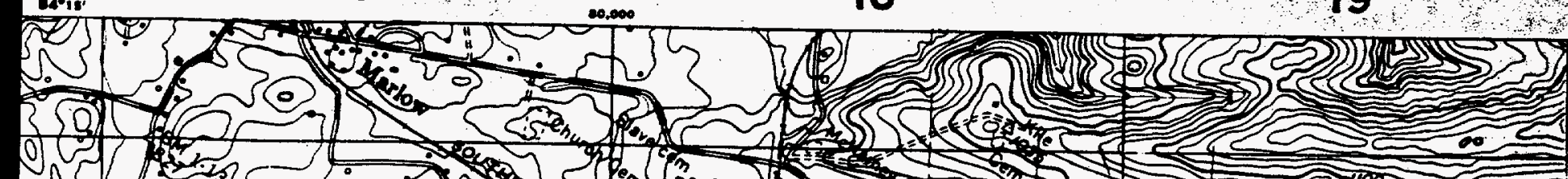
(1) N 1 12 1)

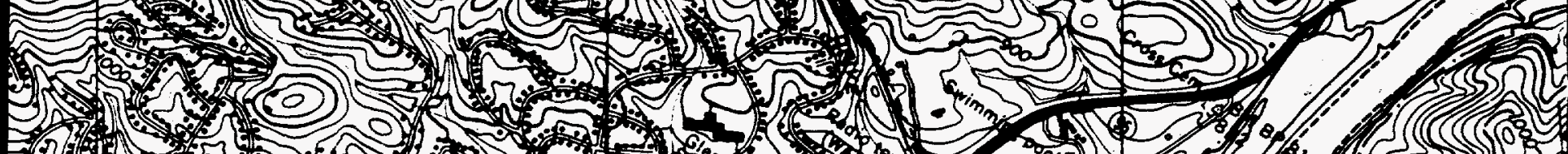
(1) $4=2,12$

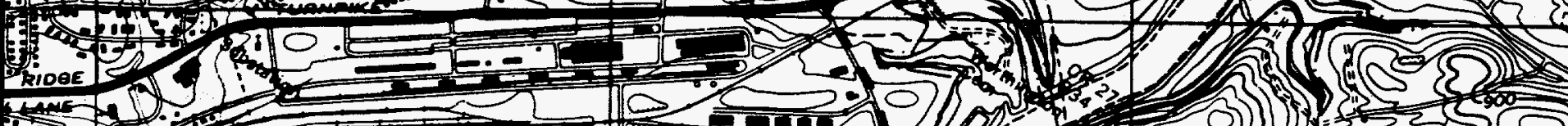
(⿸丆口) 


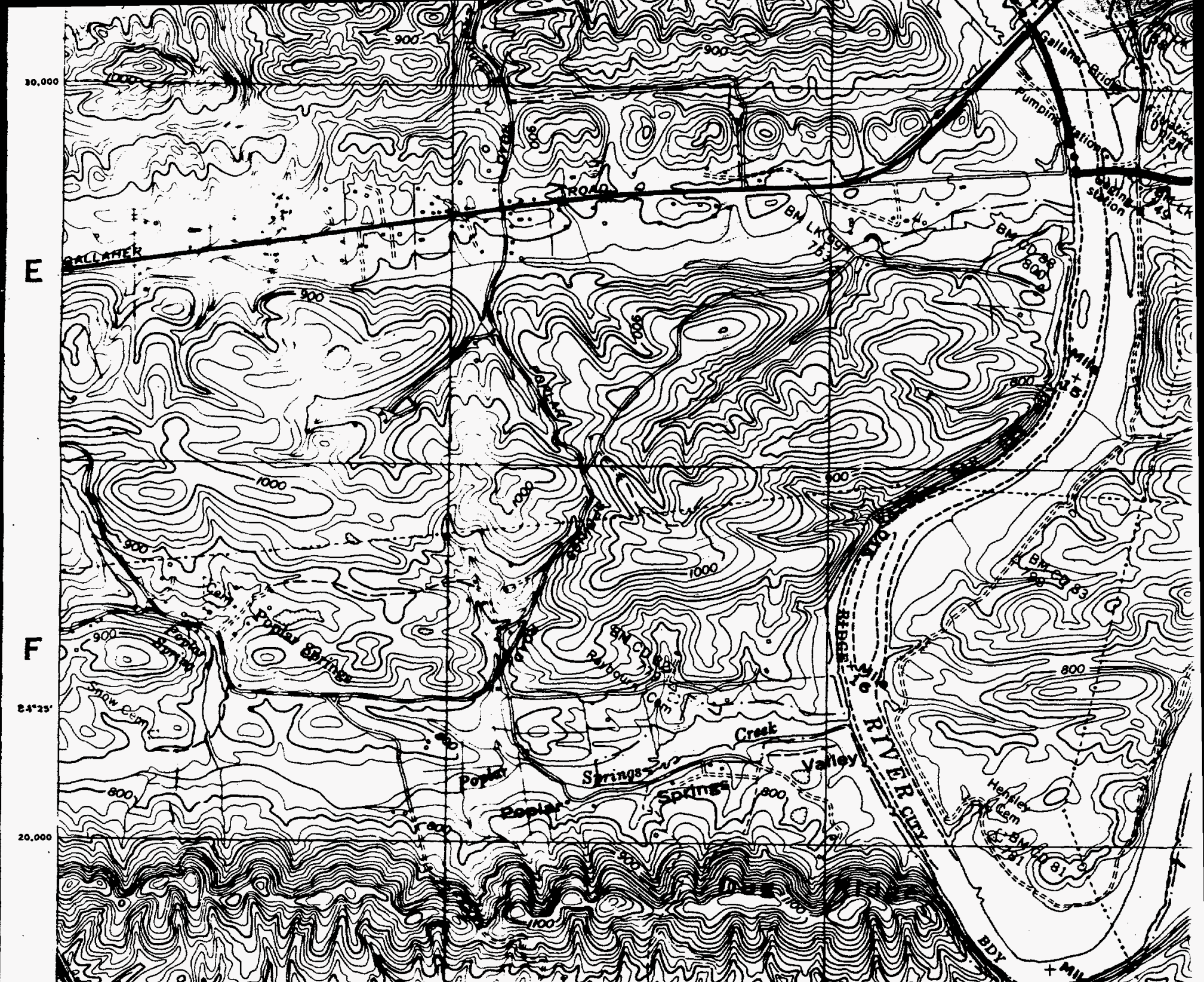

\section{G} 1.

H

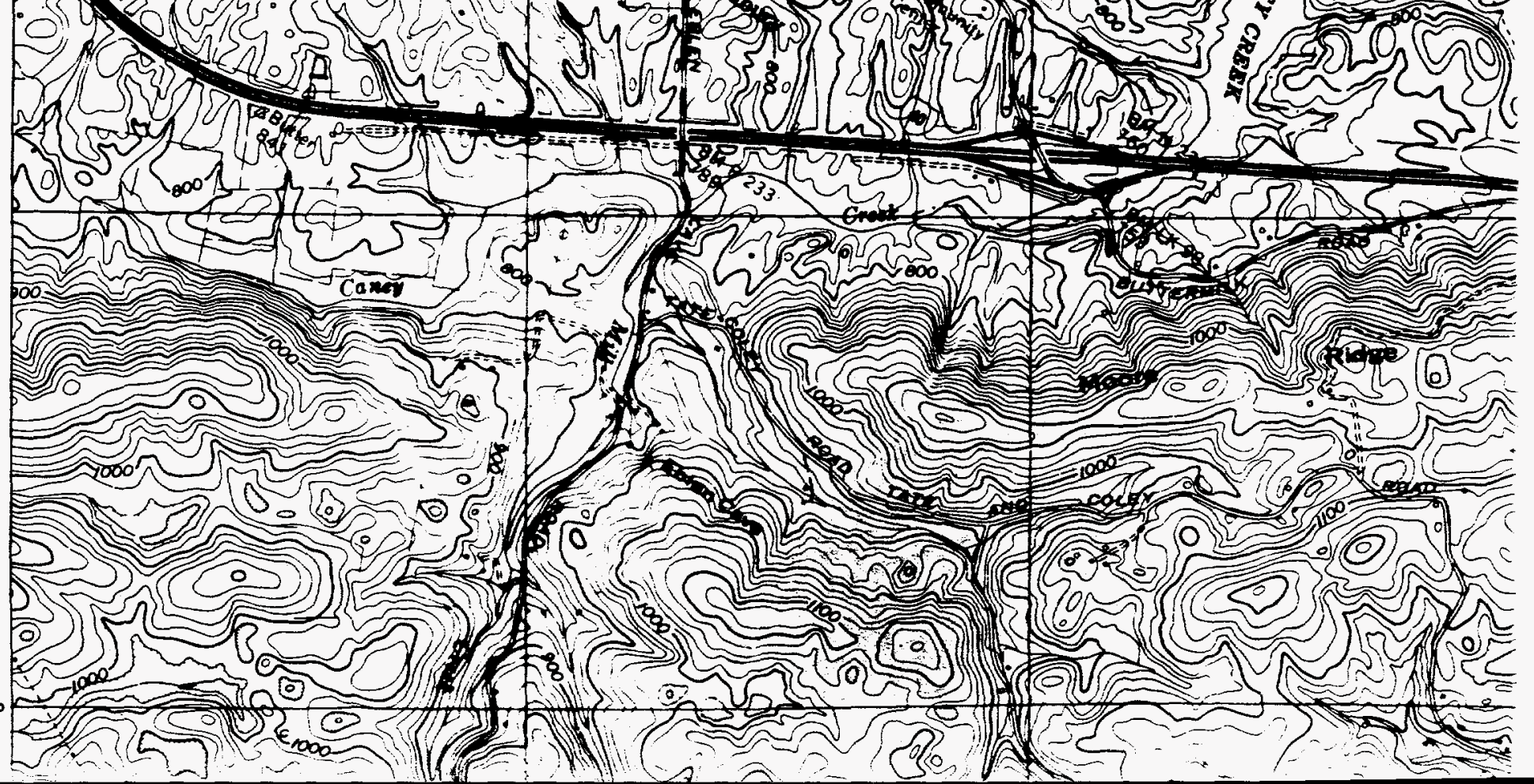


lofer (1)

(12)

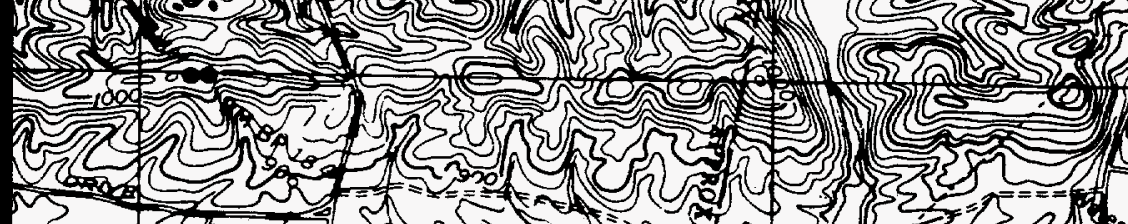

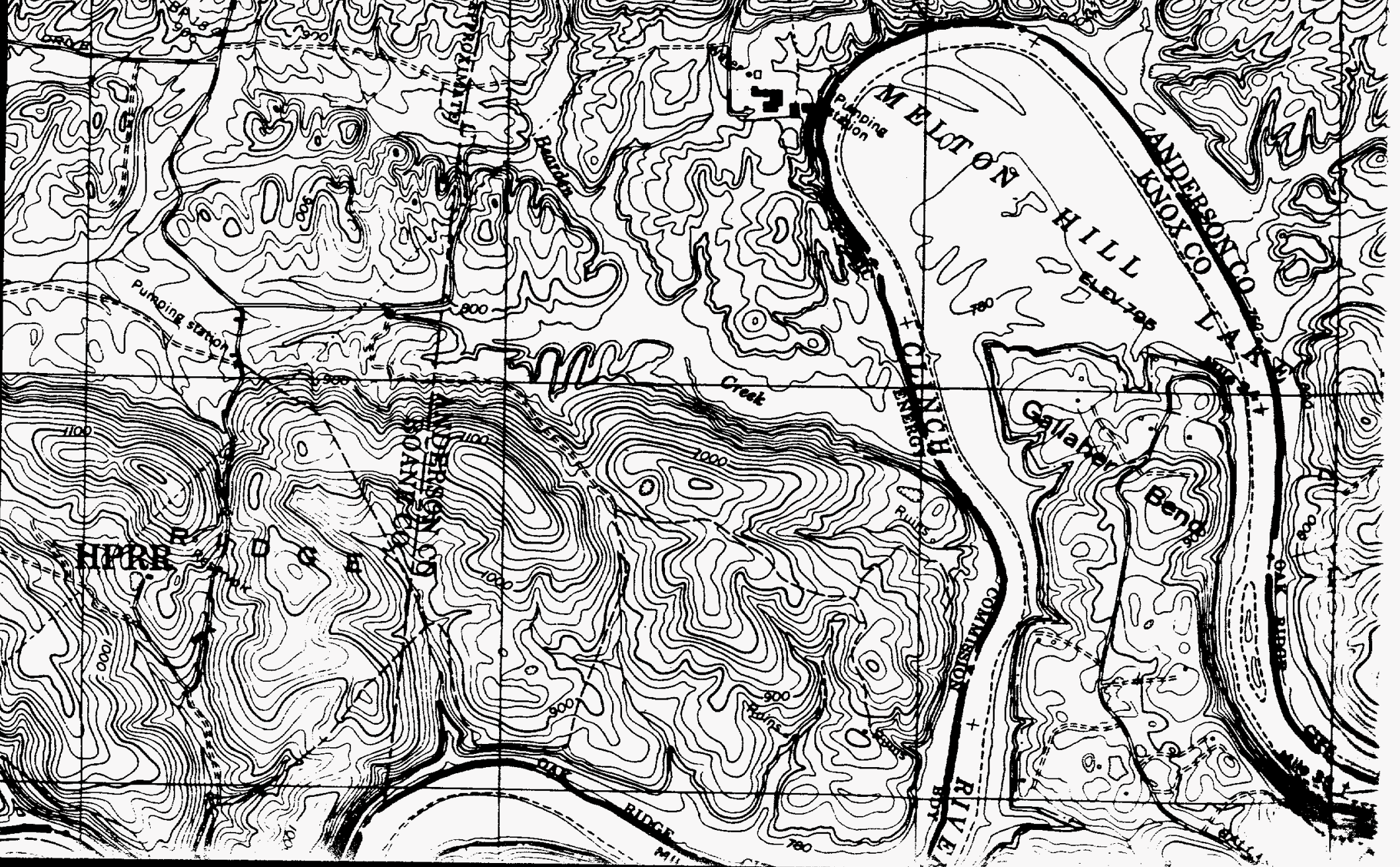




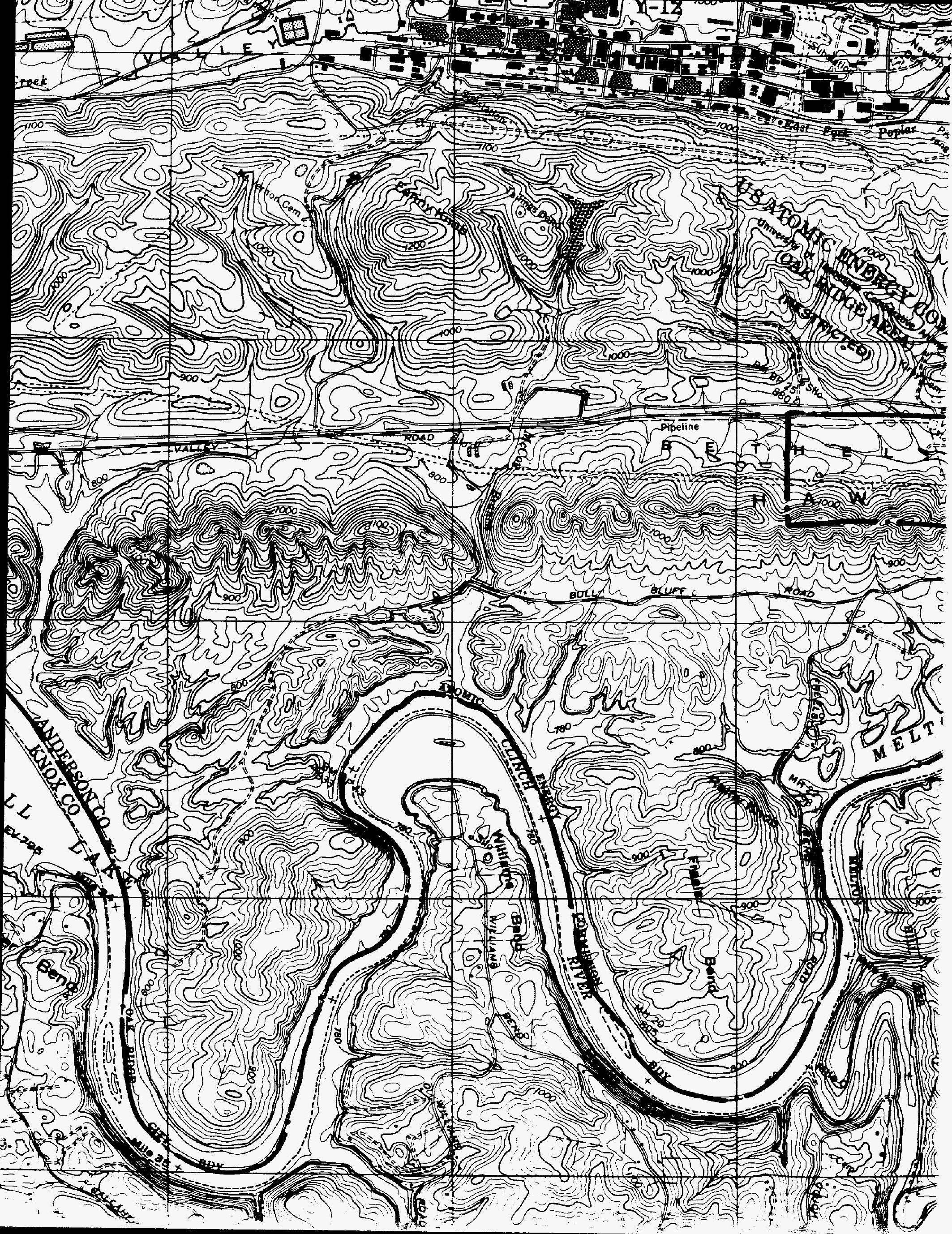




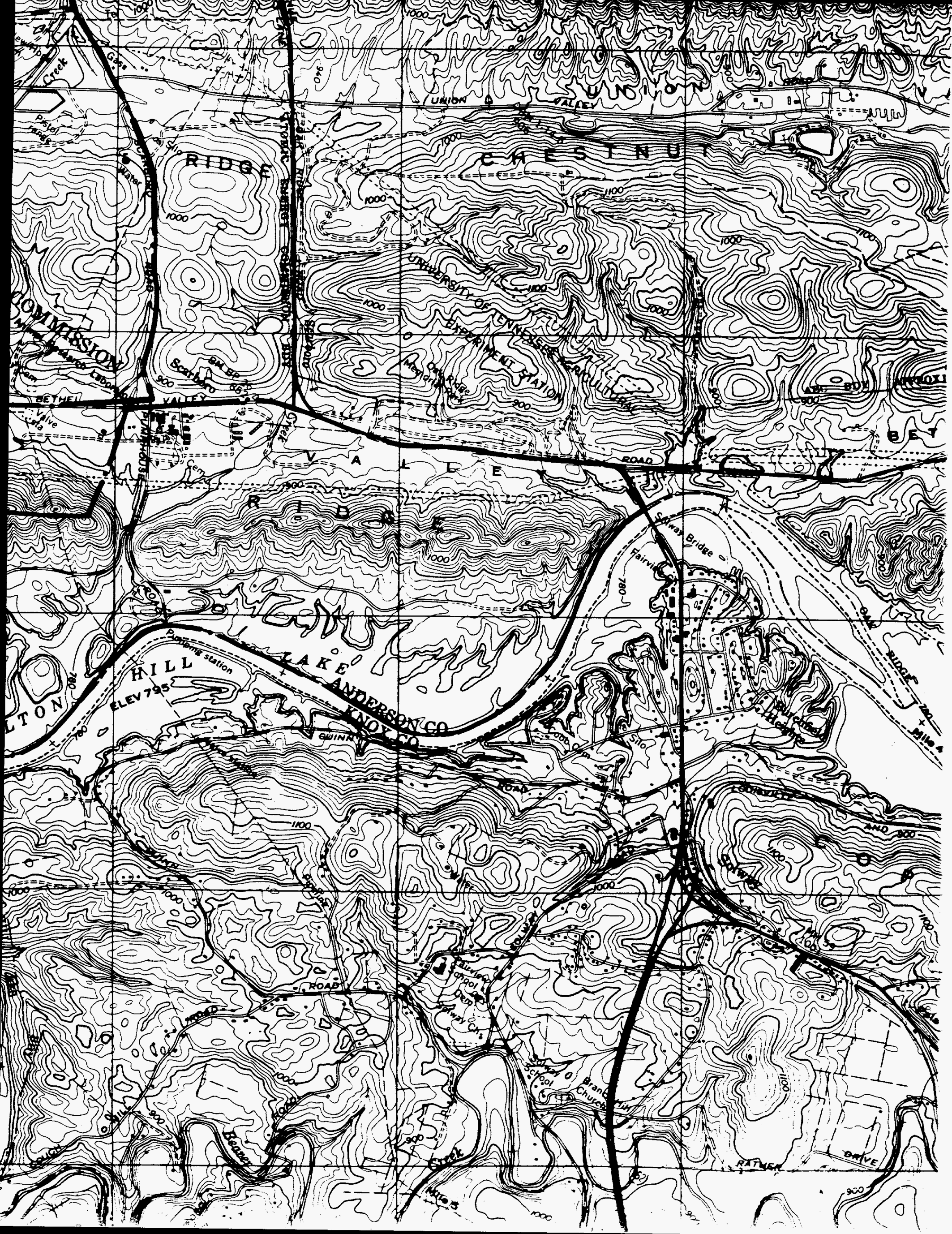




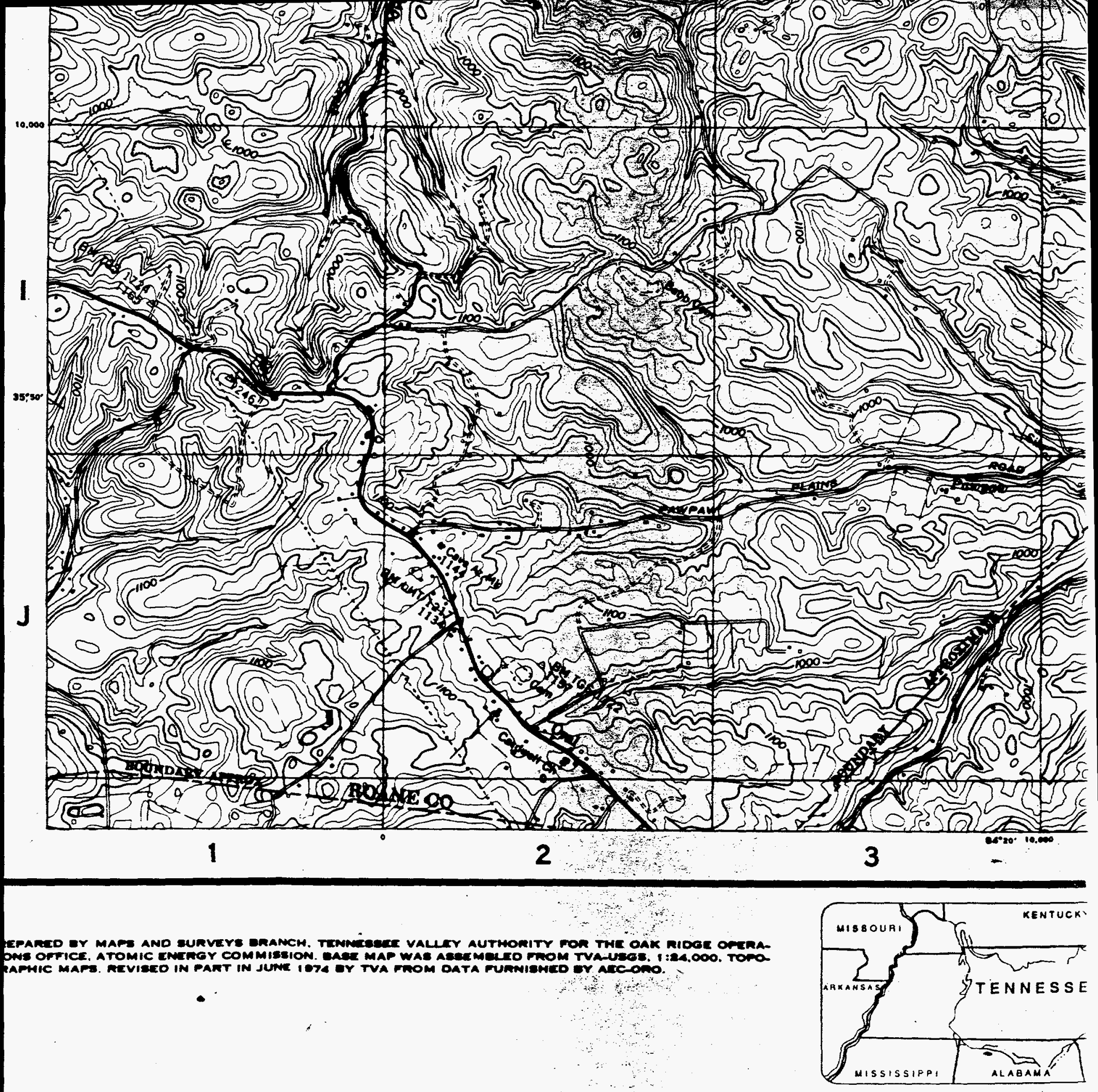



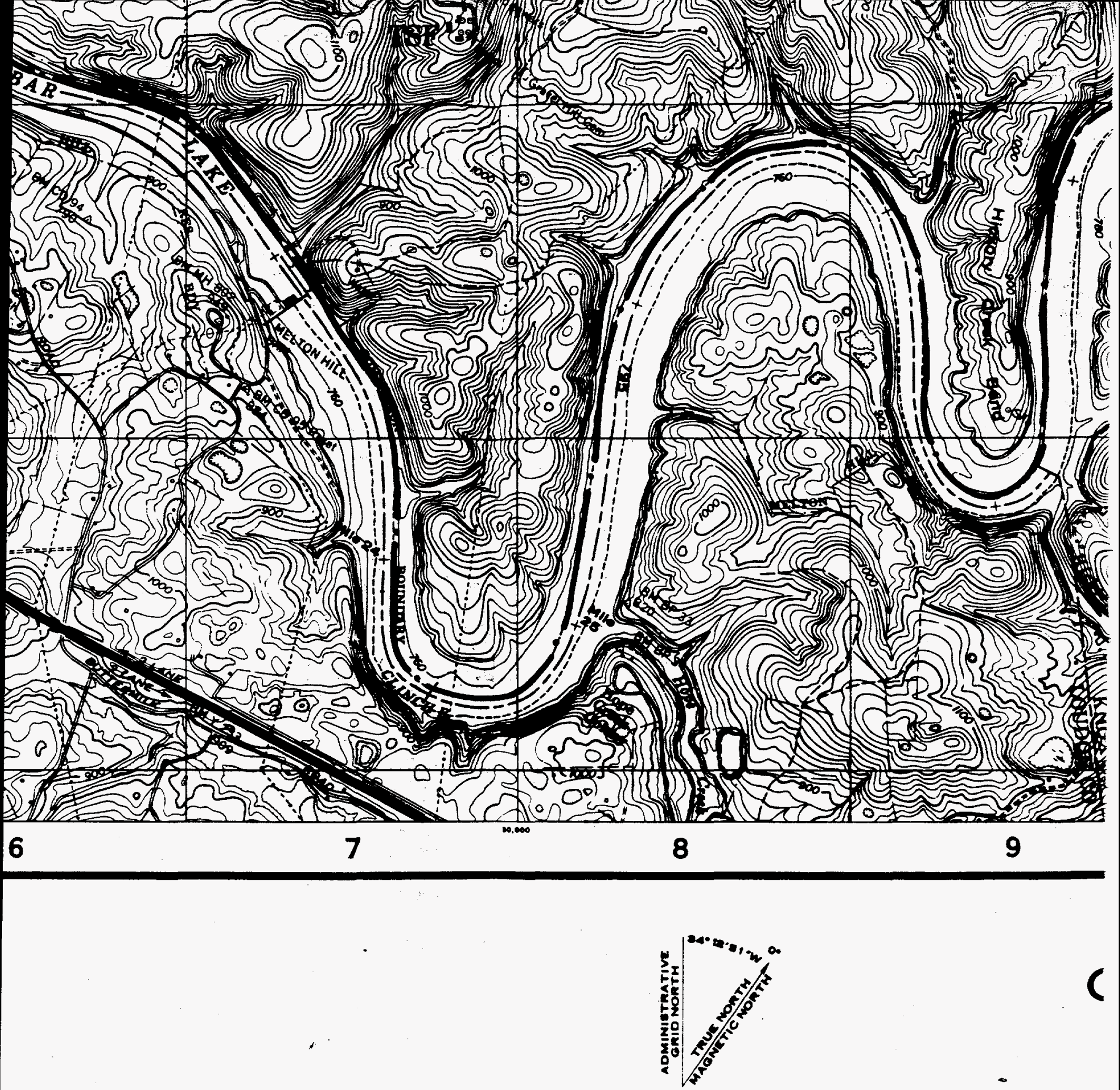


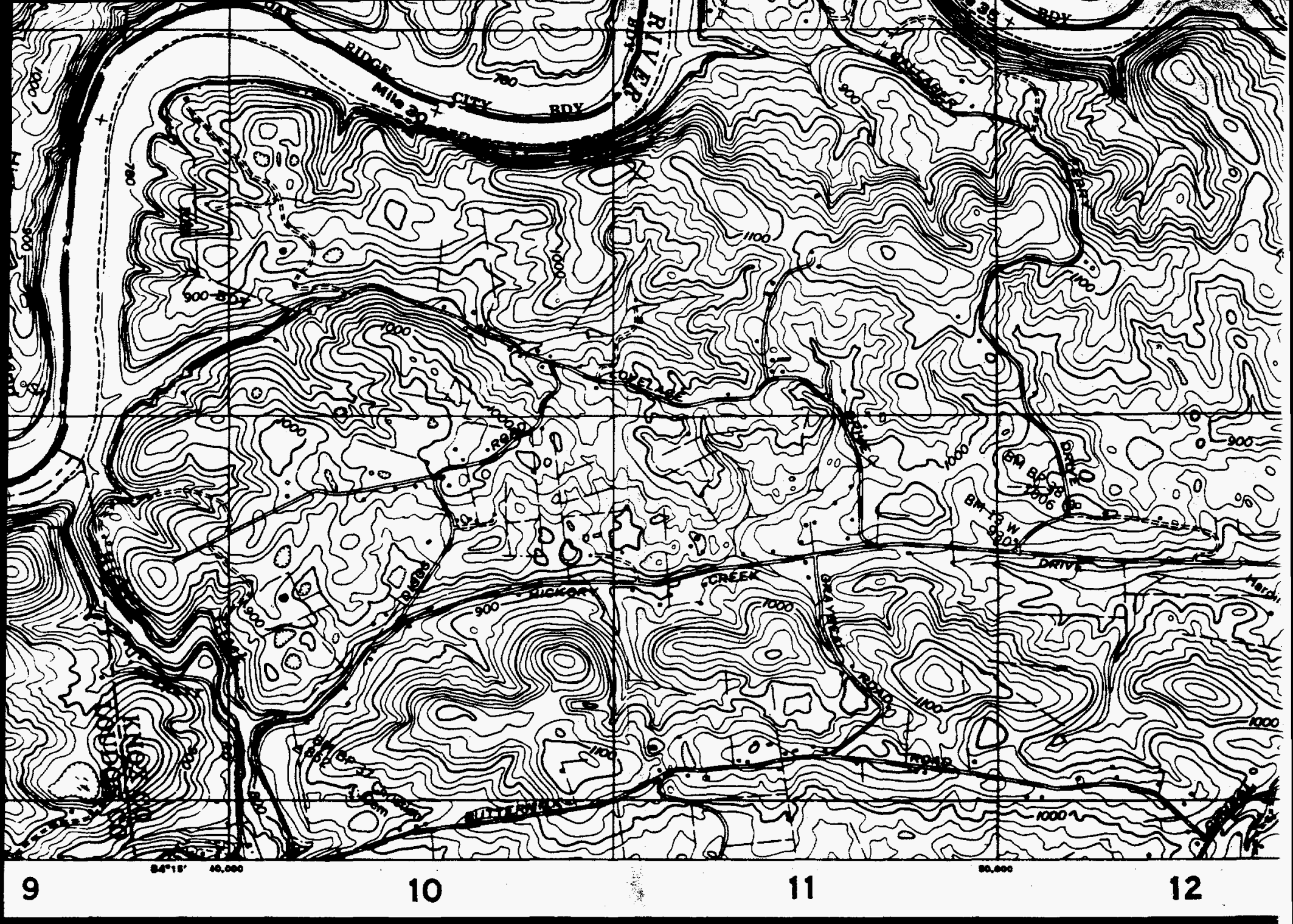

\section{OAK RIDGE, TENNESSEE}




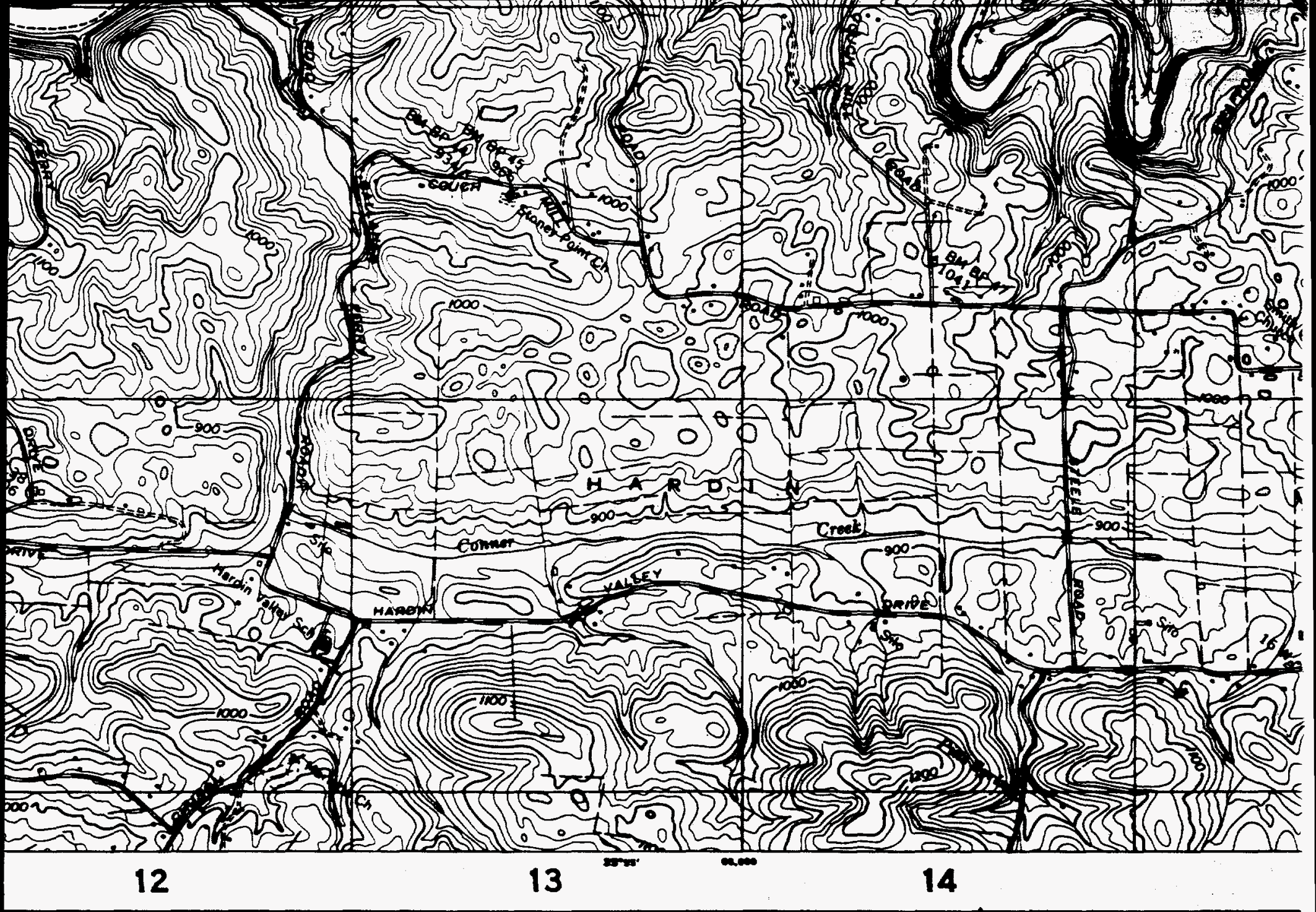

SCALE 1:2

NIC mousction

a amenican datum

1 1000

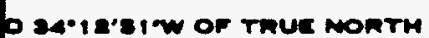

com roun mintem unval $0000 \mathrm{met}$

oarum to mean 


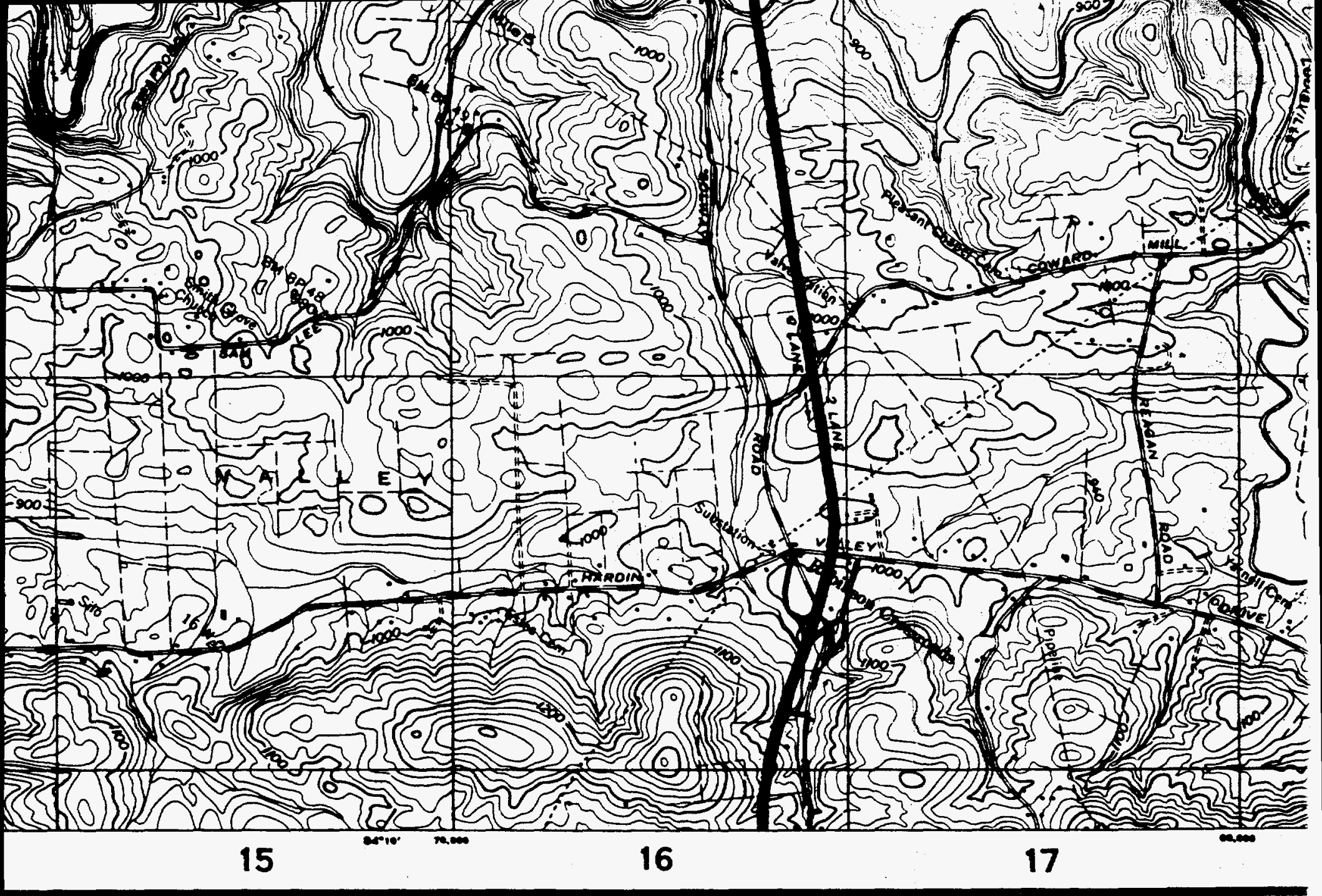

SCALE 1:24,000

(1000




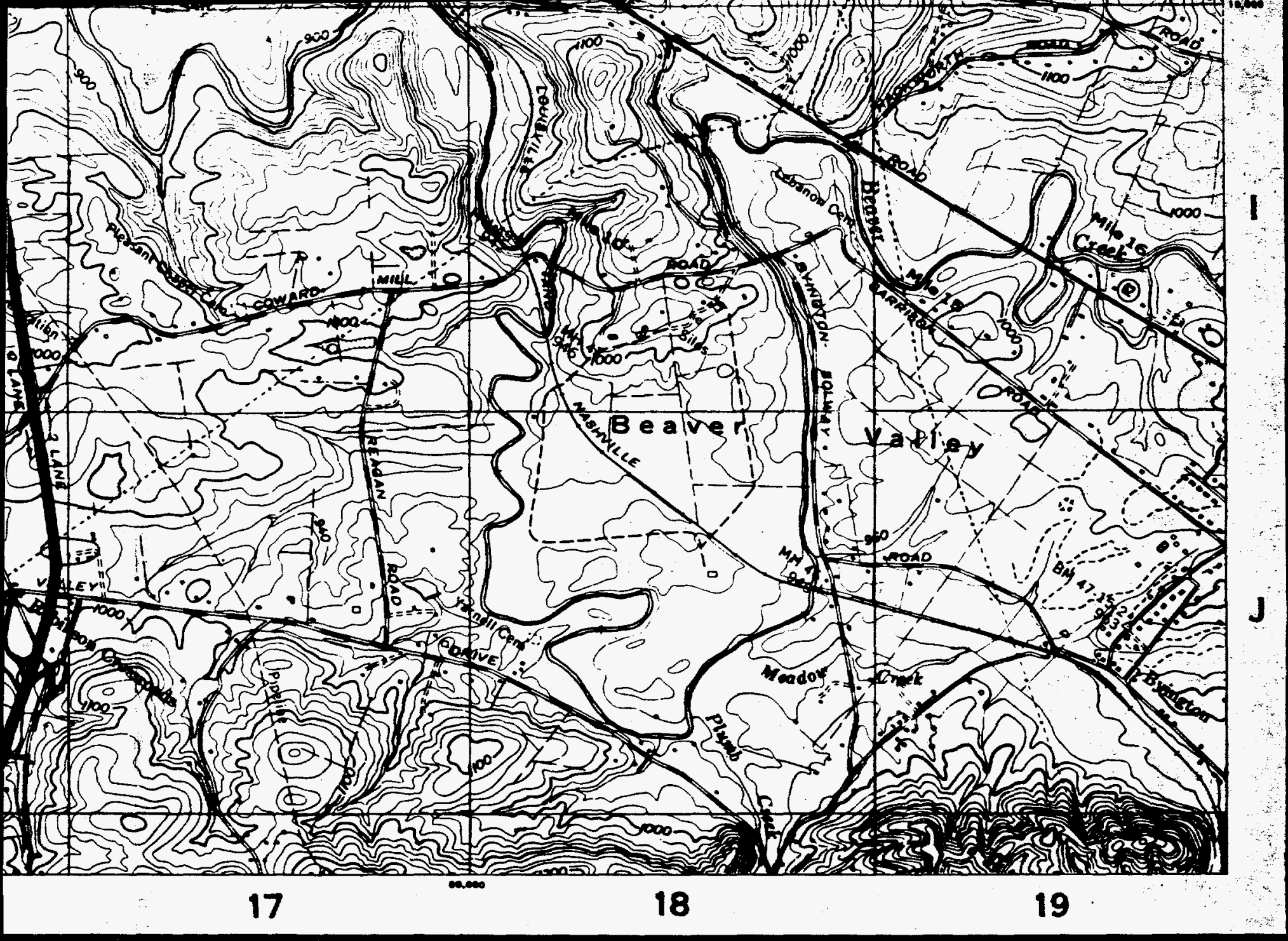

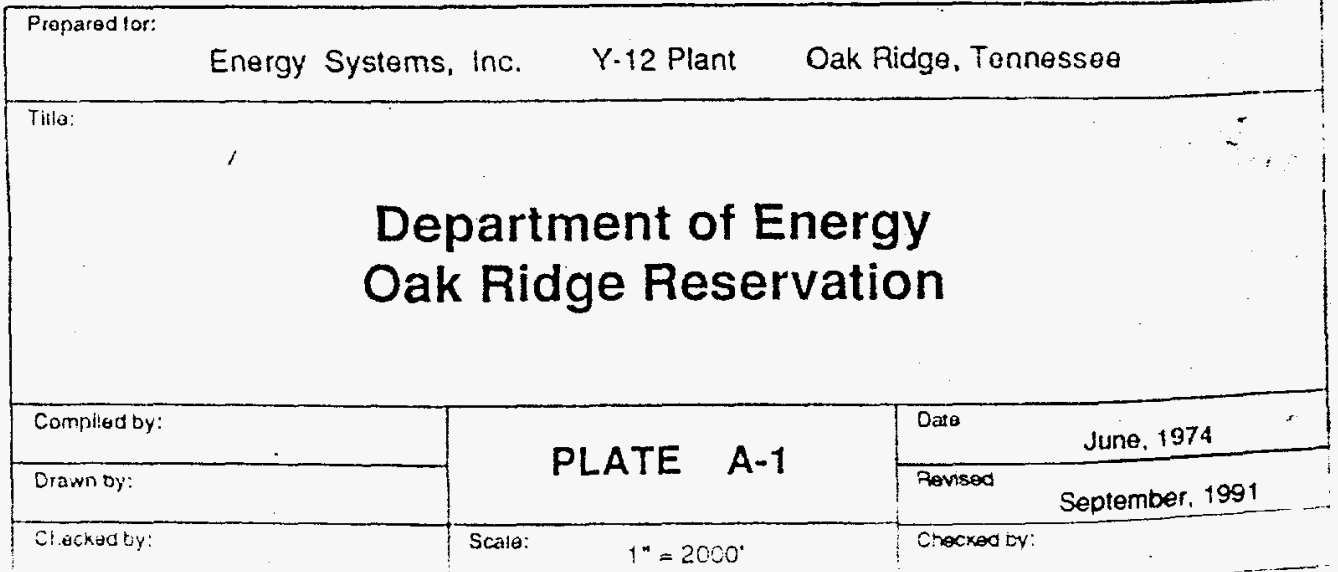



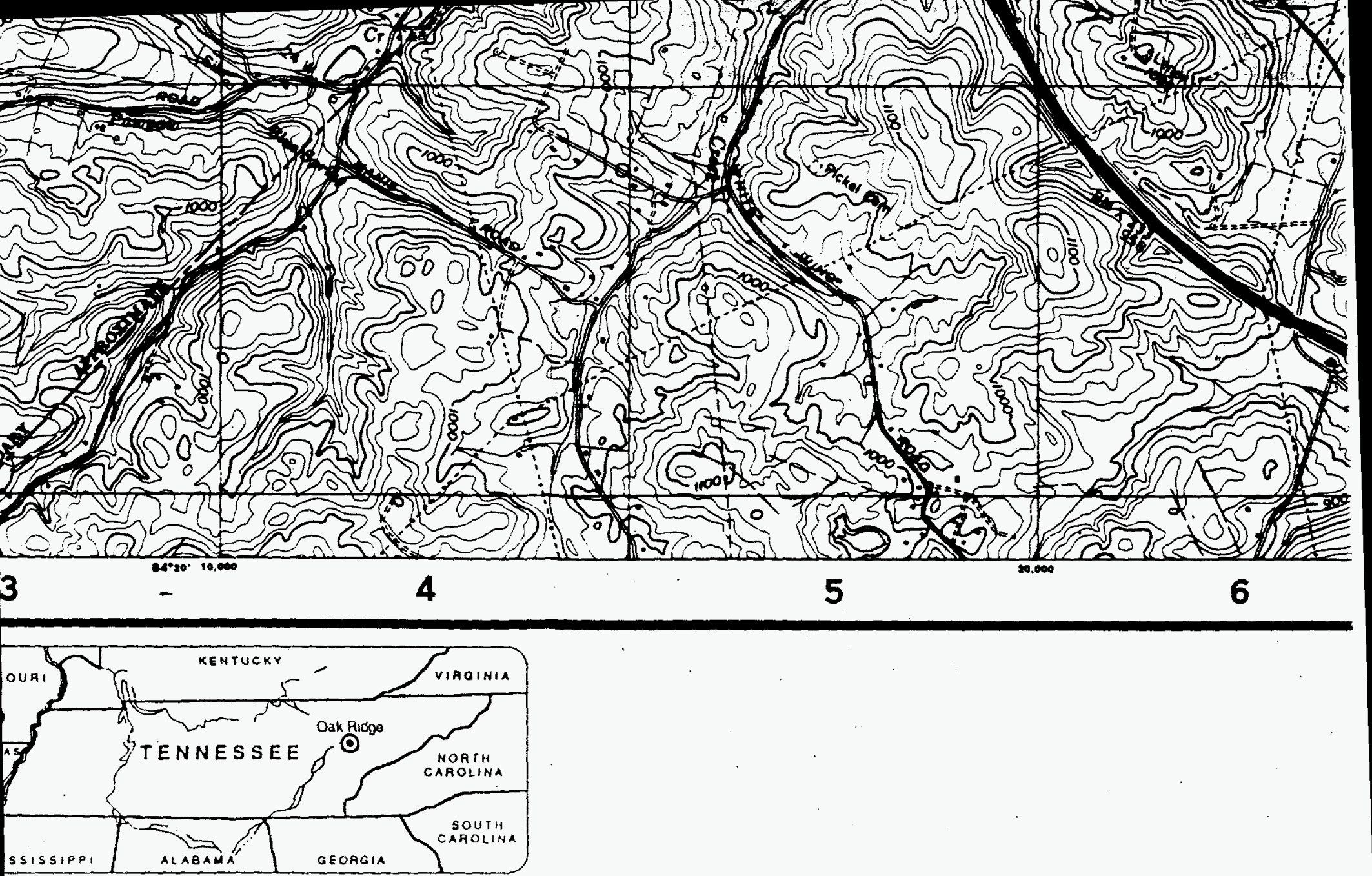

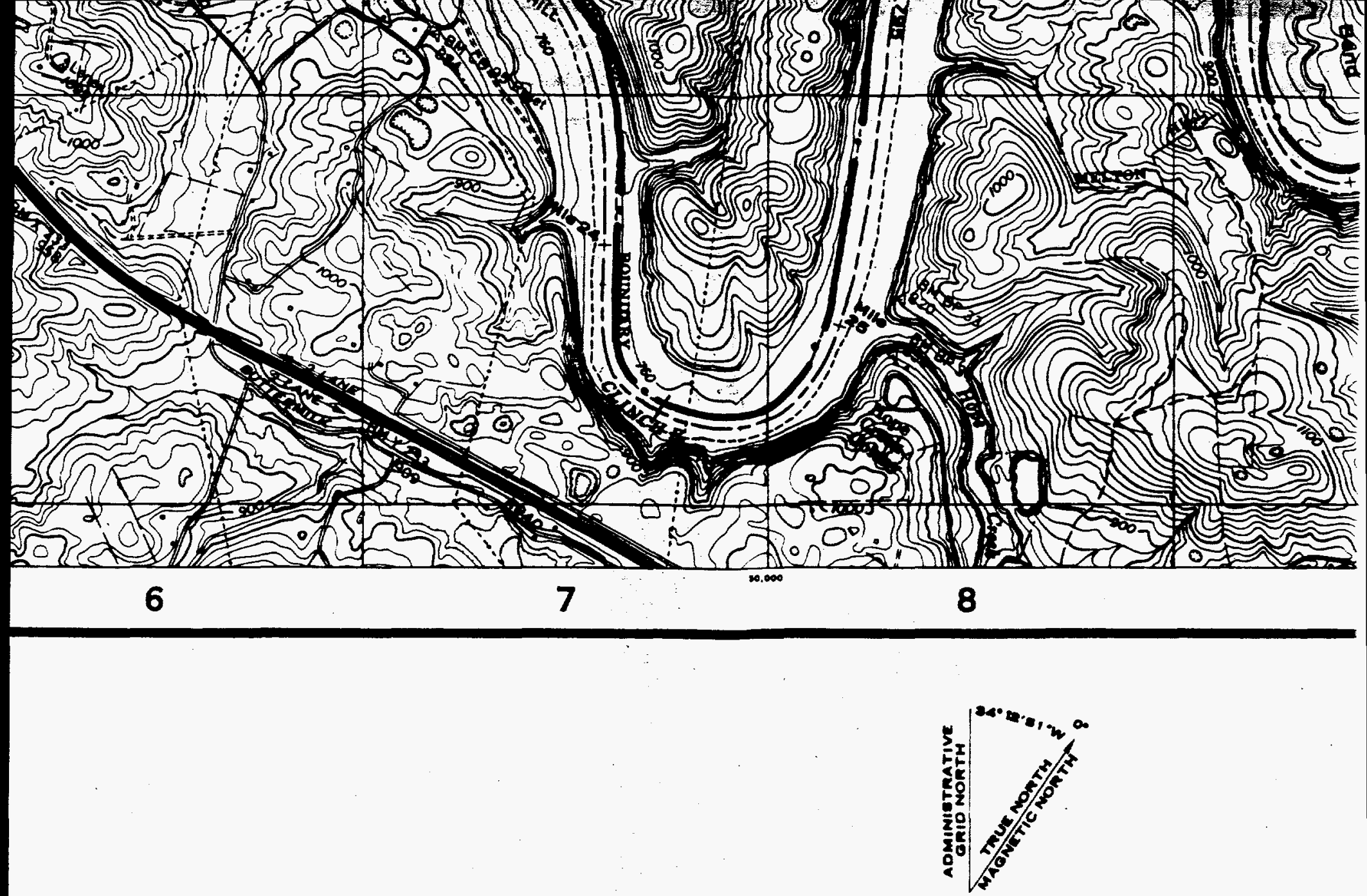

APPnOXIMATE MEAN OBCLINATION. 1074 ammual chanot ó of 


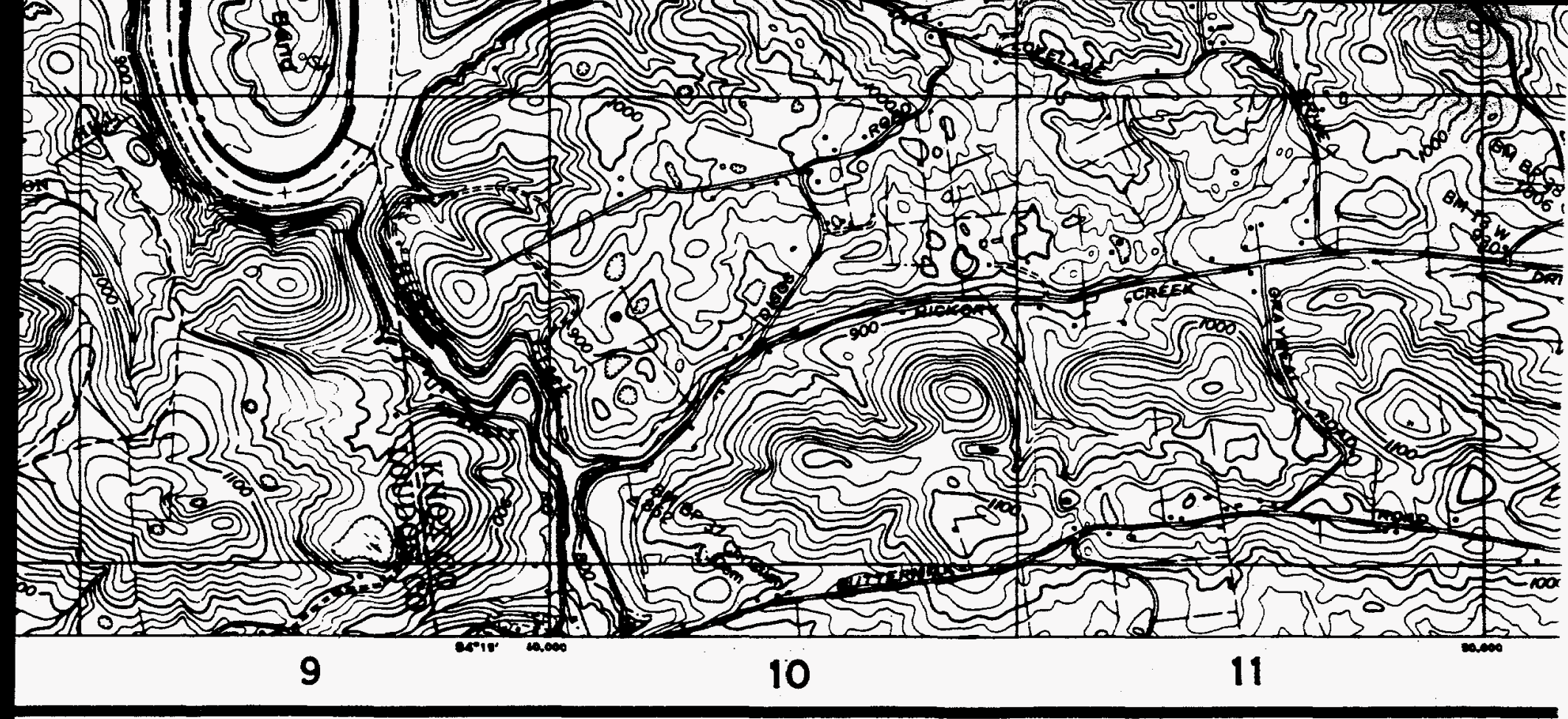

\section{OAK RIDGE AREA}

nolreowi

OAK RIDGE, TENNESSEE

DECLINATION OF ONIO

onio inte 


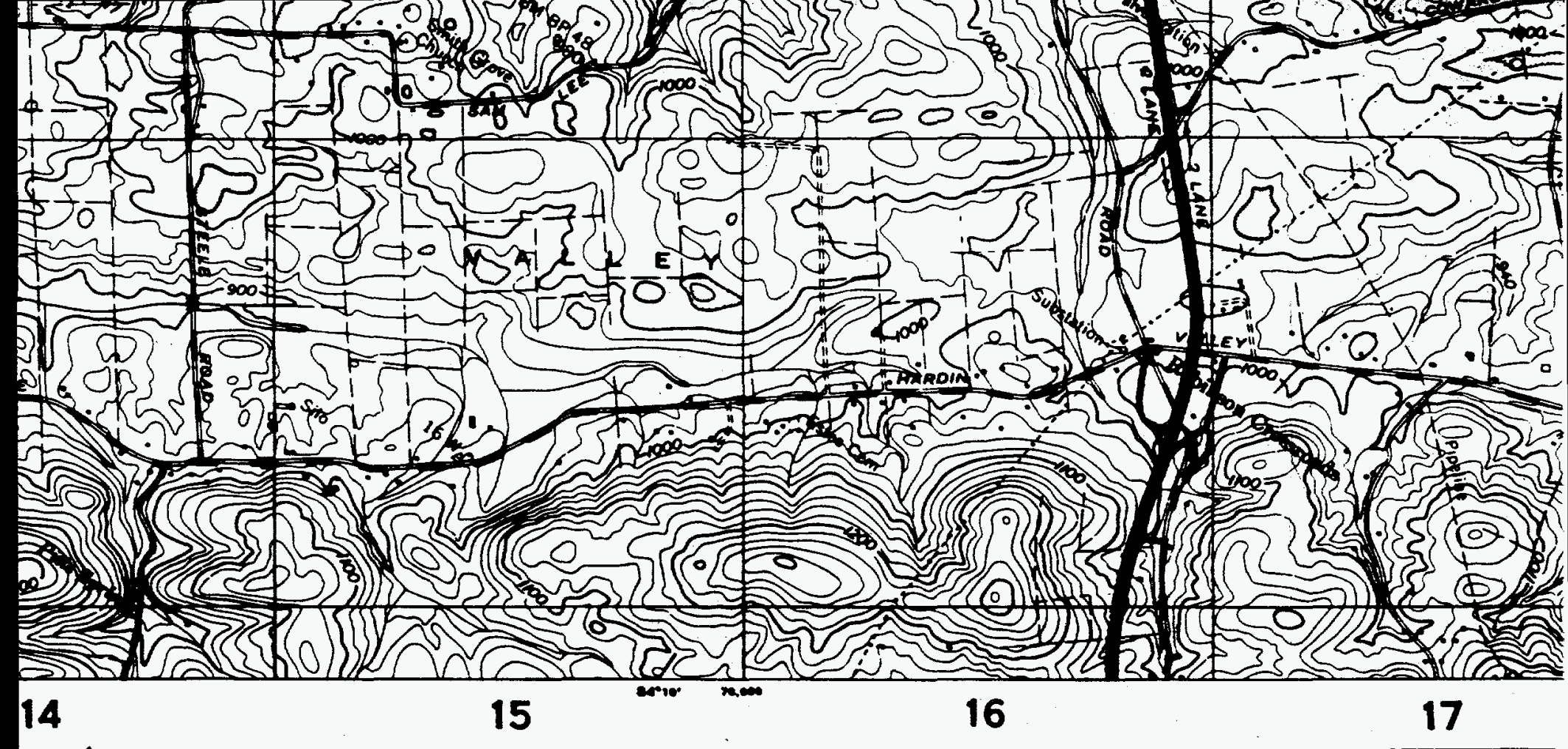

SCALE 1:24,000

2

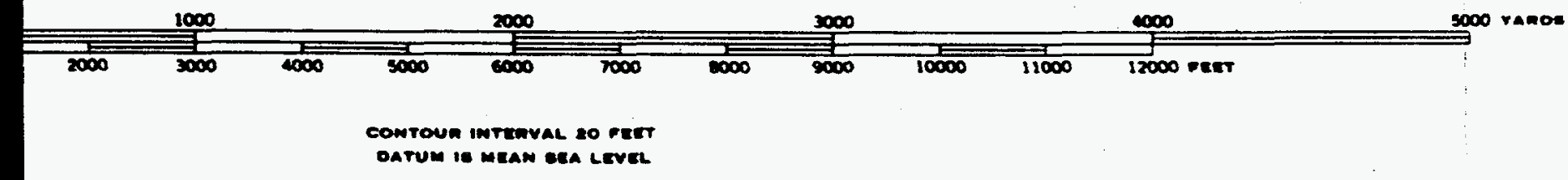




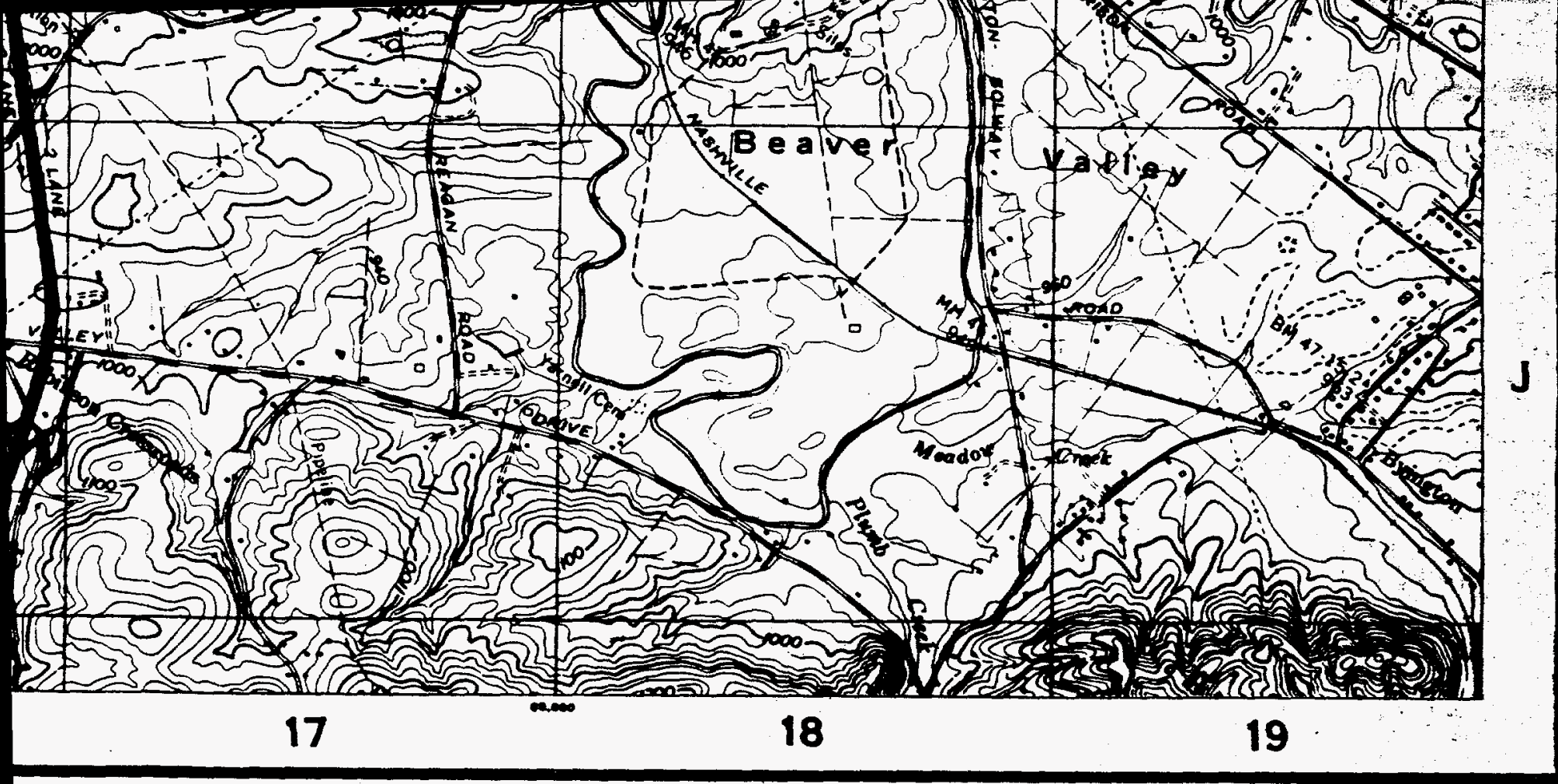

3 แnะ

son ramos

S-16A

JUNE 1074

\begin{tabular}{|c|c|c|c|c|}
\hline Prepared tor: & \multicolumn{4}{|c|}{ Oak Ridge, Tonnessee } \\
\hline \multicolumn{5}{|c|}{$\begin{array}{l}\text { Department of Energy } \\
\text { Oak Ridge Reservation }\end{array}$} \\
\hline Compllea by: & & \multirow{2}{*}{ PLATE A-1 } & Date & June, 1974 \\
\hline Drawn by: & & & fevised & September, 1991 \\
\hline Checked by: & & $t^{n}=2000^{\circ}$ & Checredo & . \\
\hline
\end{tabular}




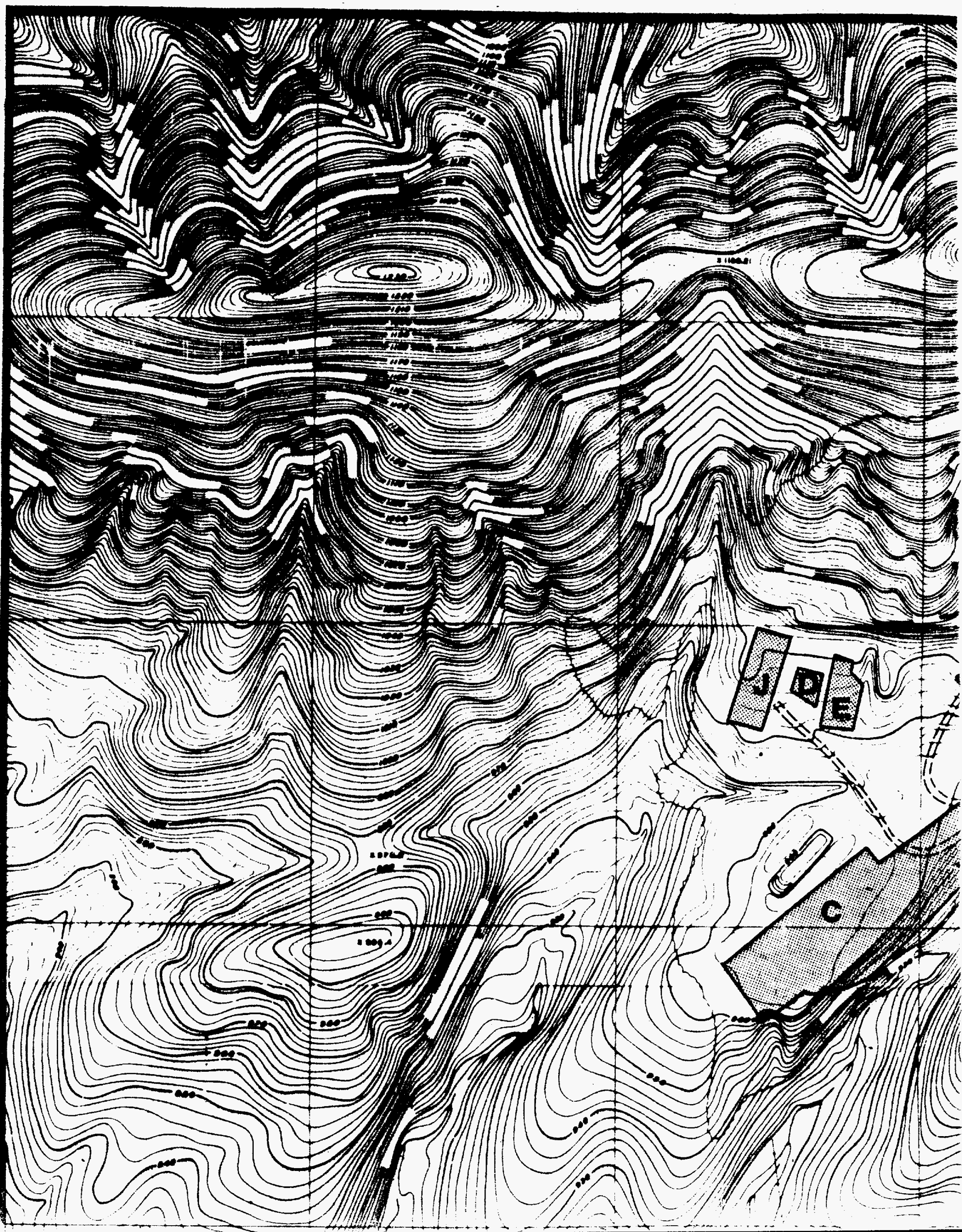




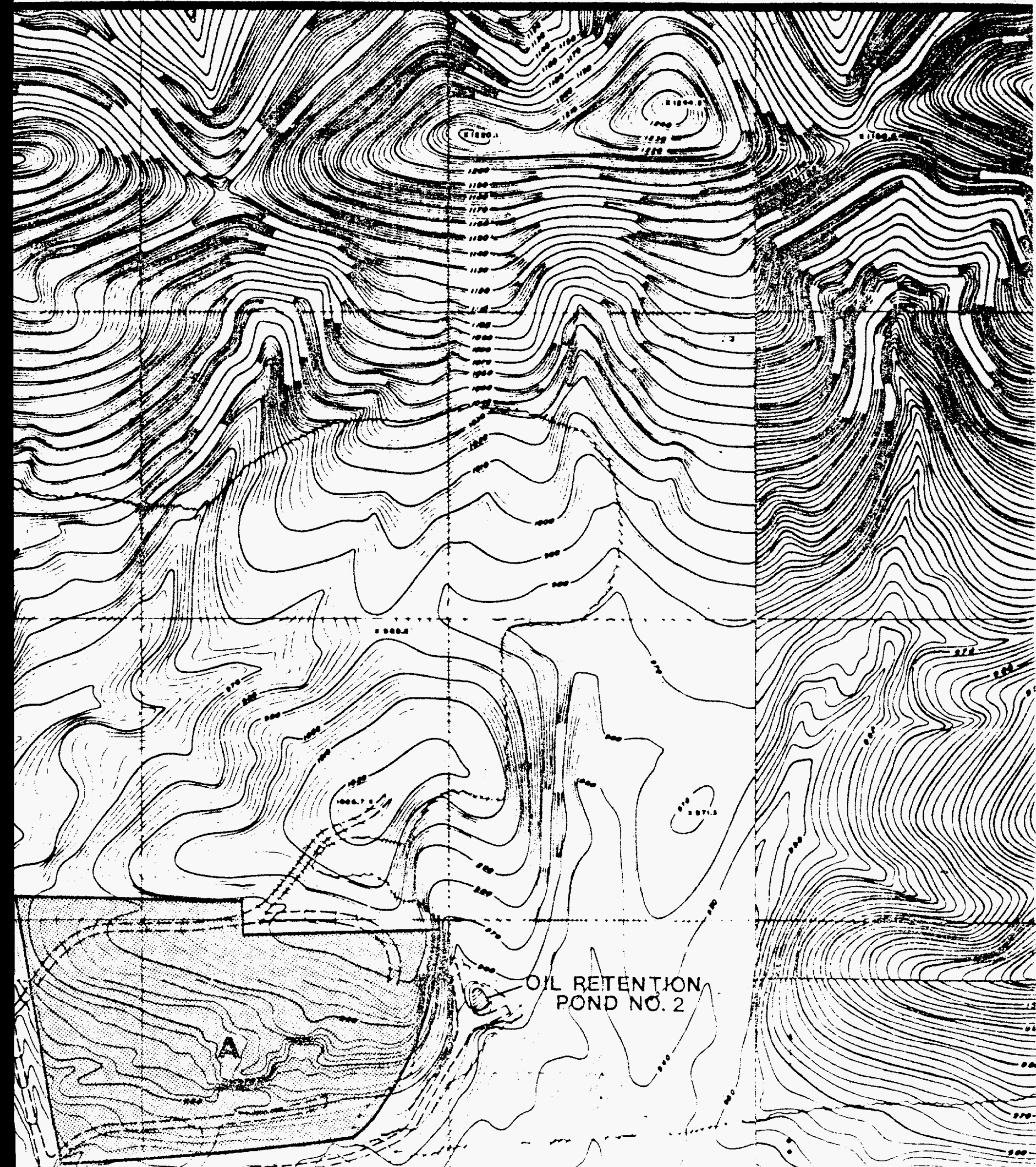




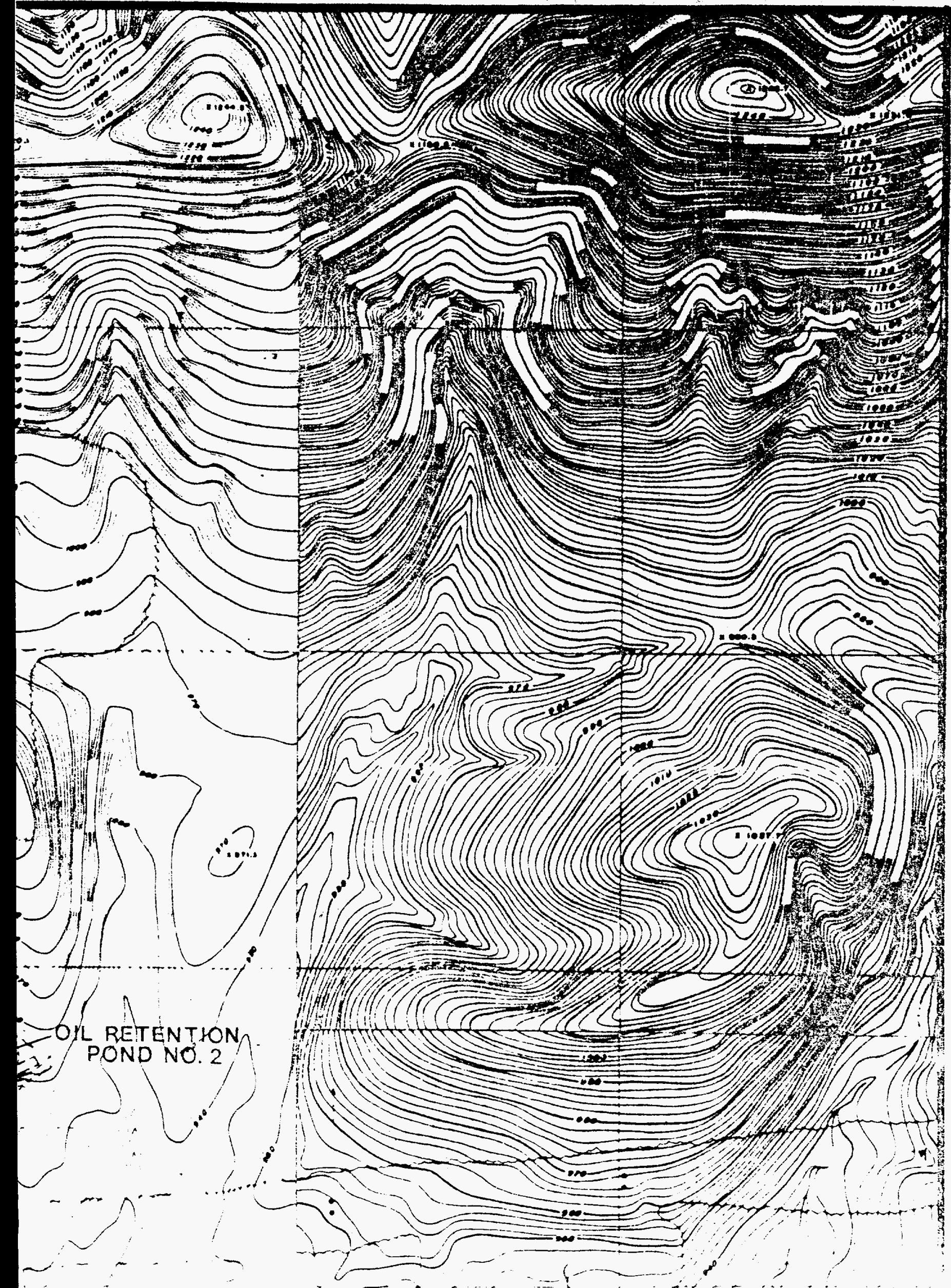

N 31,000 


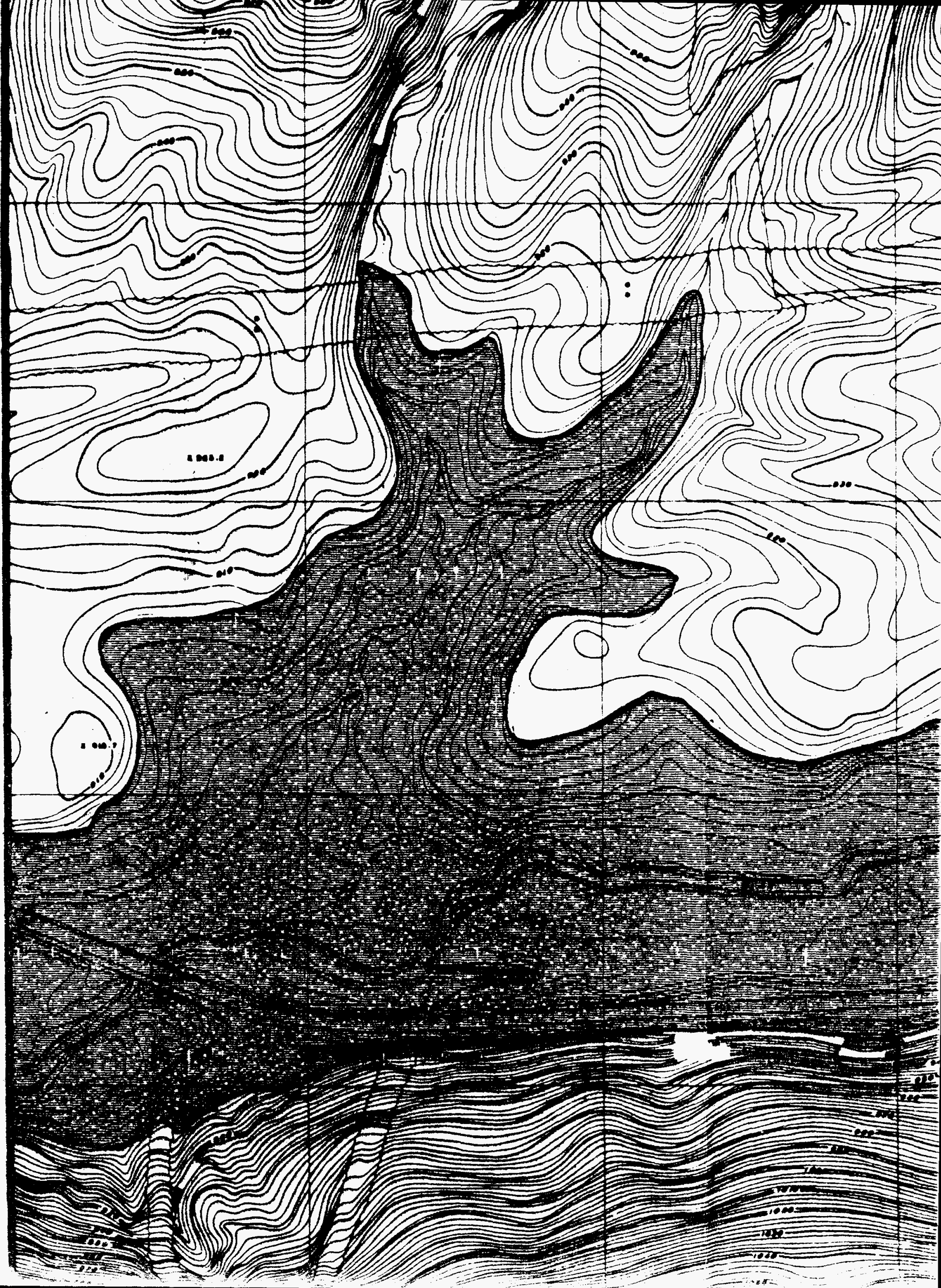



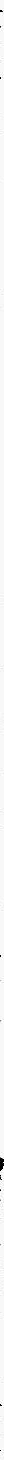

100-YEAR FLOODPLAIN

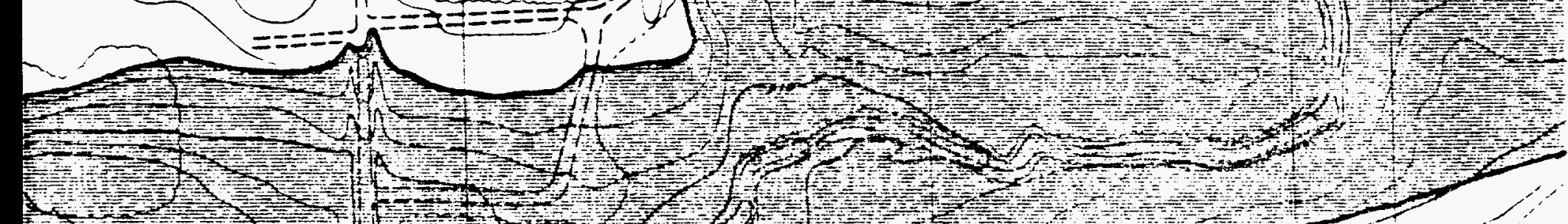

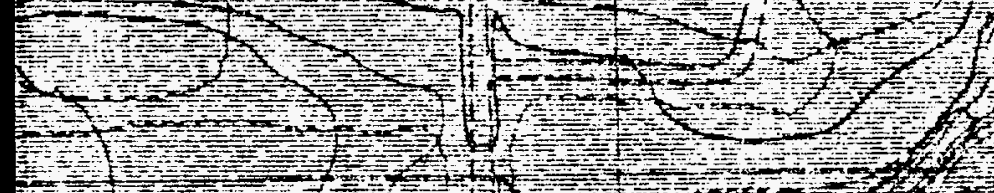

,

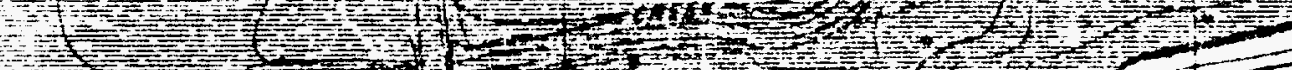

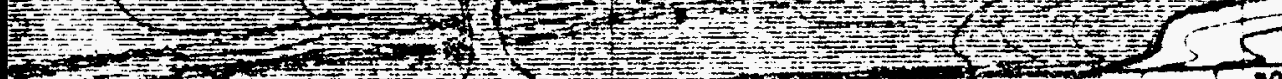

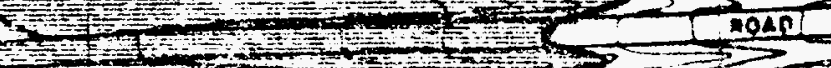

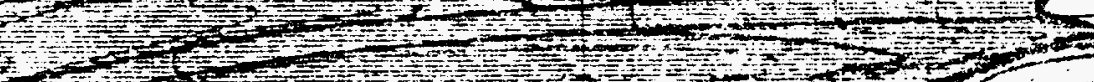

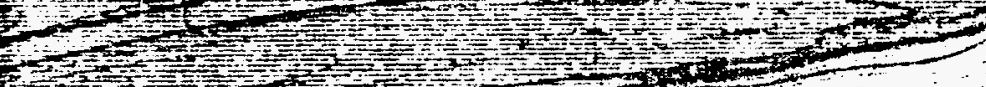

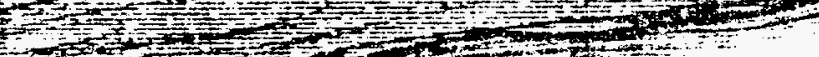

$x=121$

$\leq 000$

$7+2 z^{2}=2$

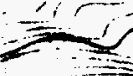

$=$

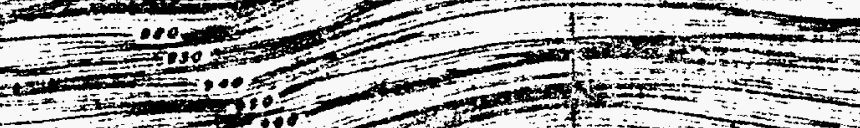

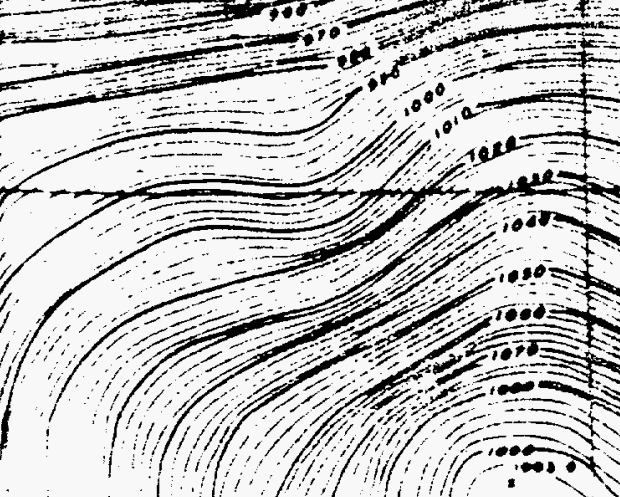




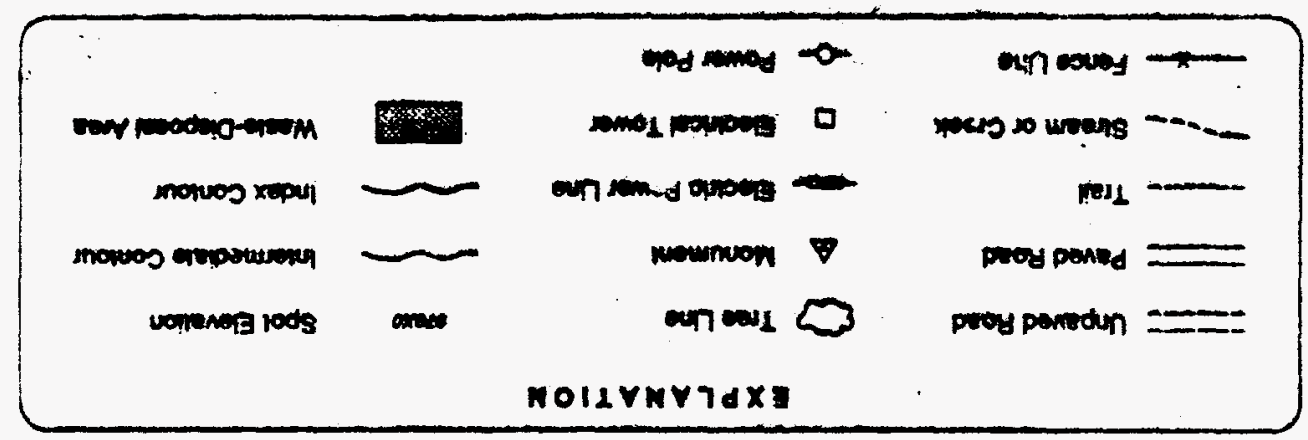

$m$
$\stackrel{0}{N}$
0
0

$m$
\pm
0
0

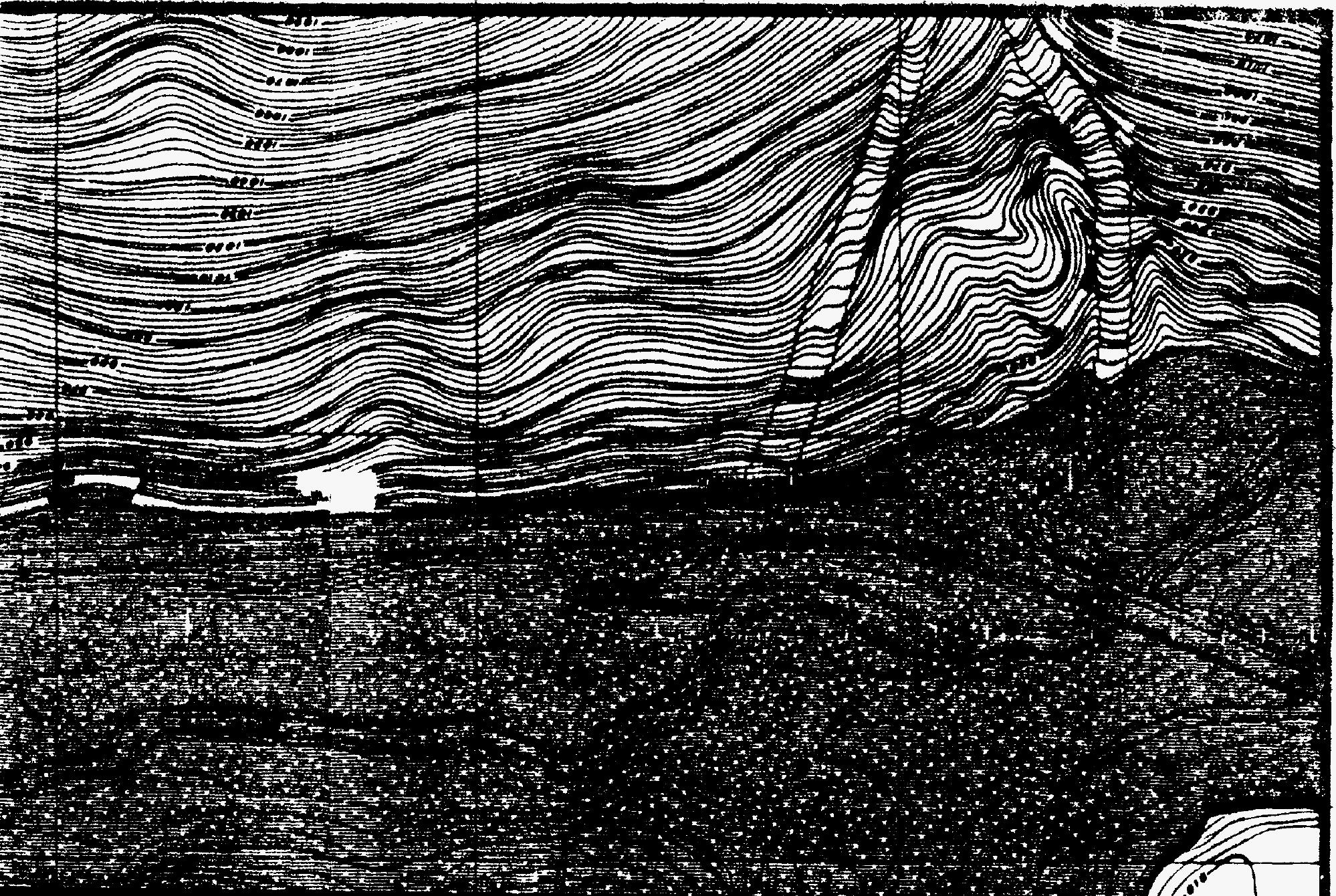




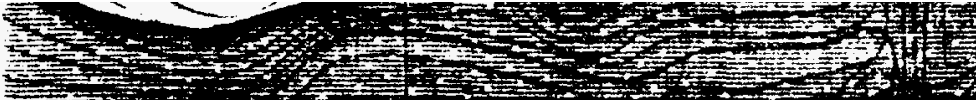

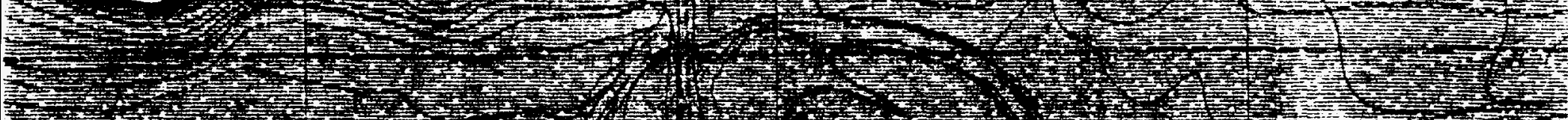
20

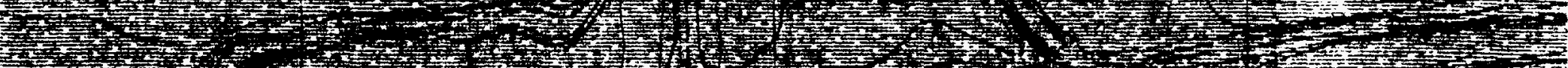

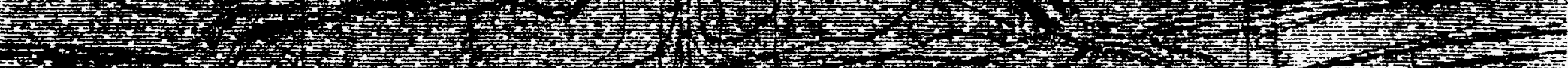

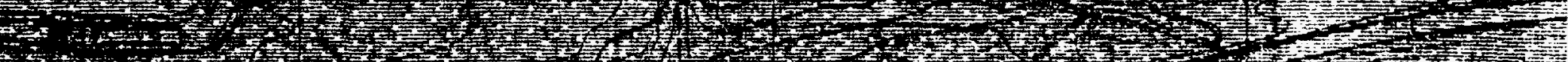

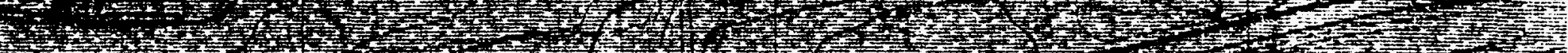

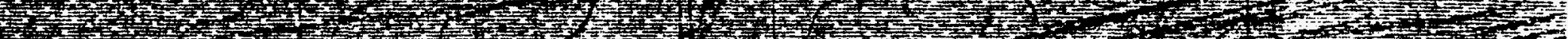

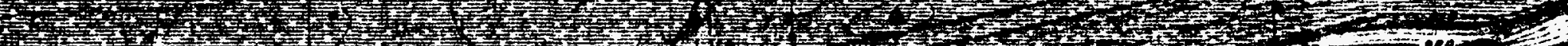

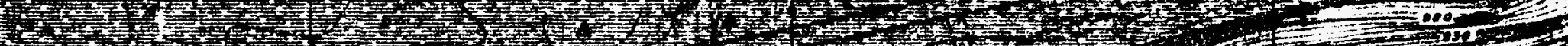

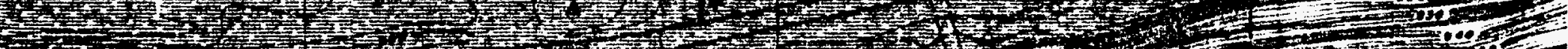

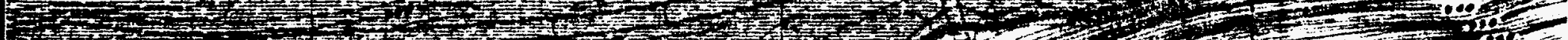

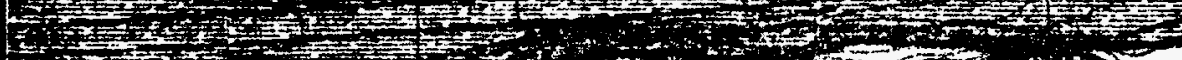

促

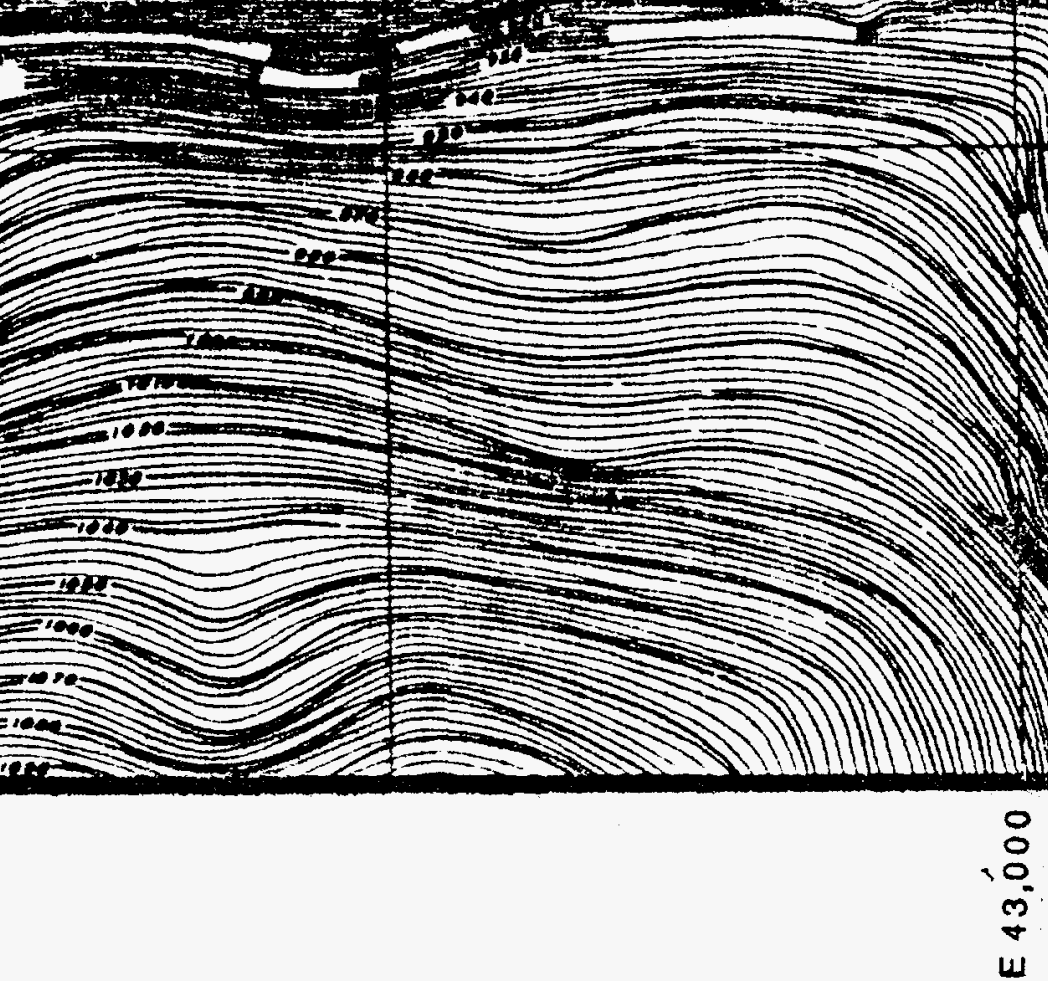

0
0
0
$\pi$
W

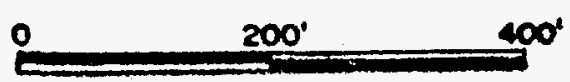

BCALE $1^{\circ}-200^{\circ}$

CONTOUR INTERVAL $2^{\circ}$
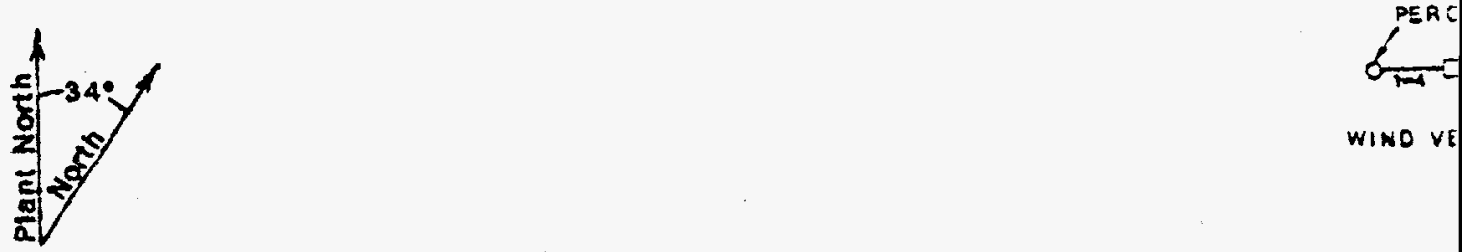

WINO VE 
$\frac{1}{2}$ (1)

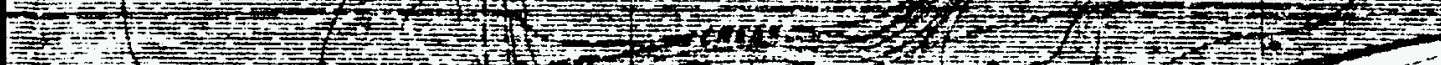

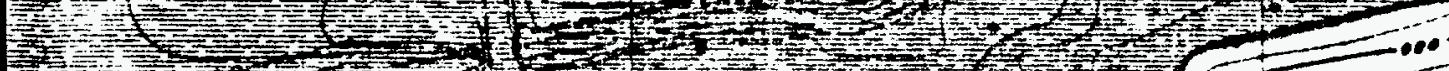

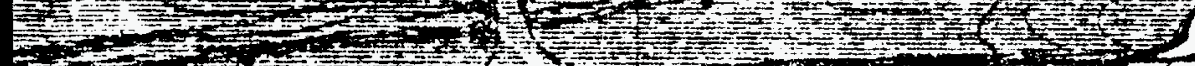

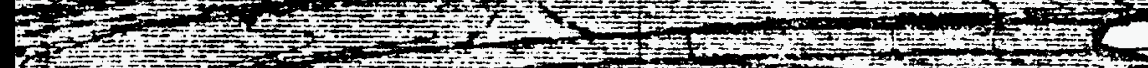

31

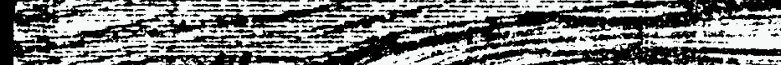

$+2=0$

20

00

$+2+1$

ac

(2)

2
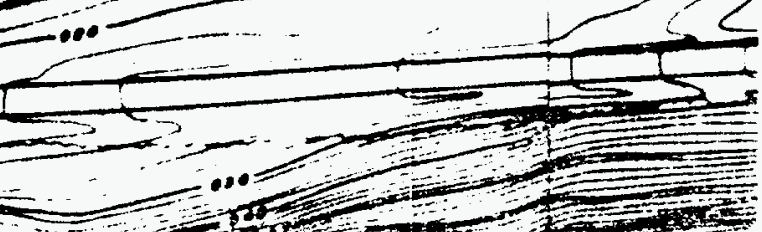

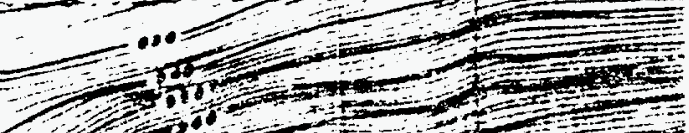

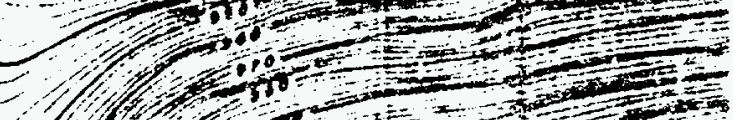
110 $=010$ $-1$

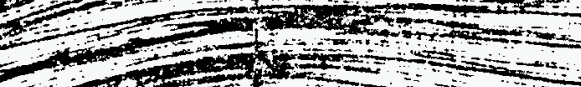
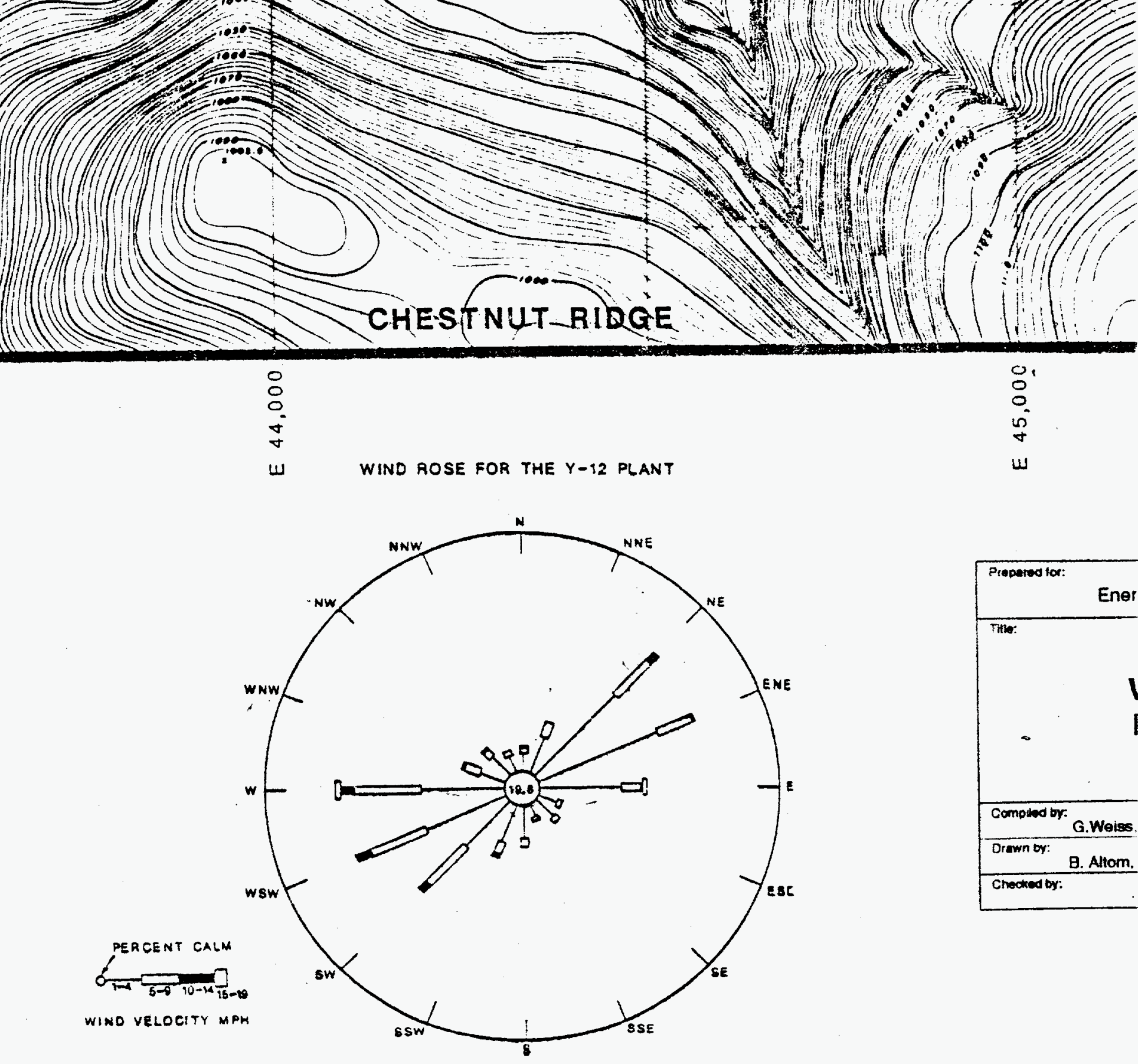


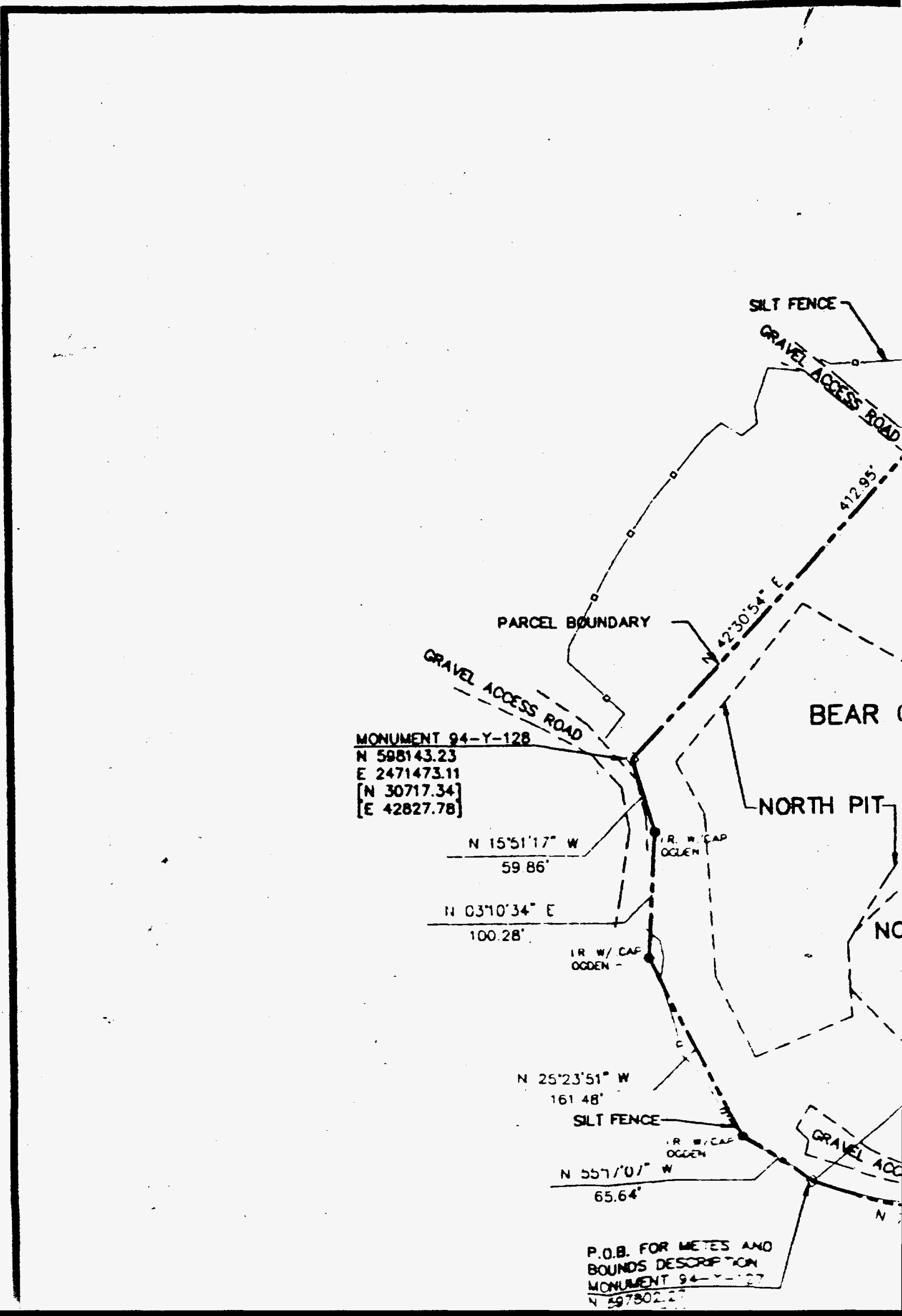




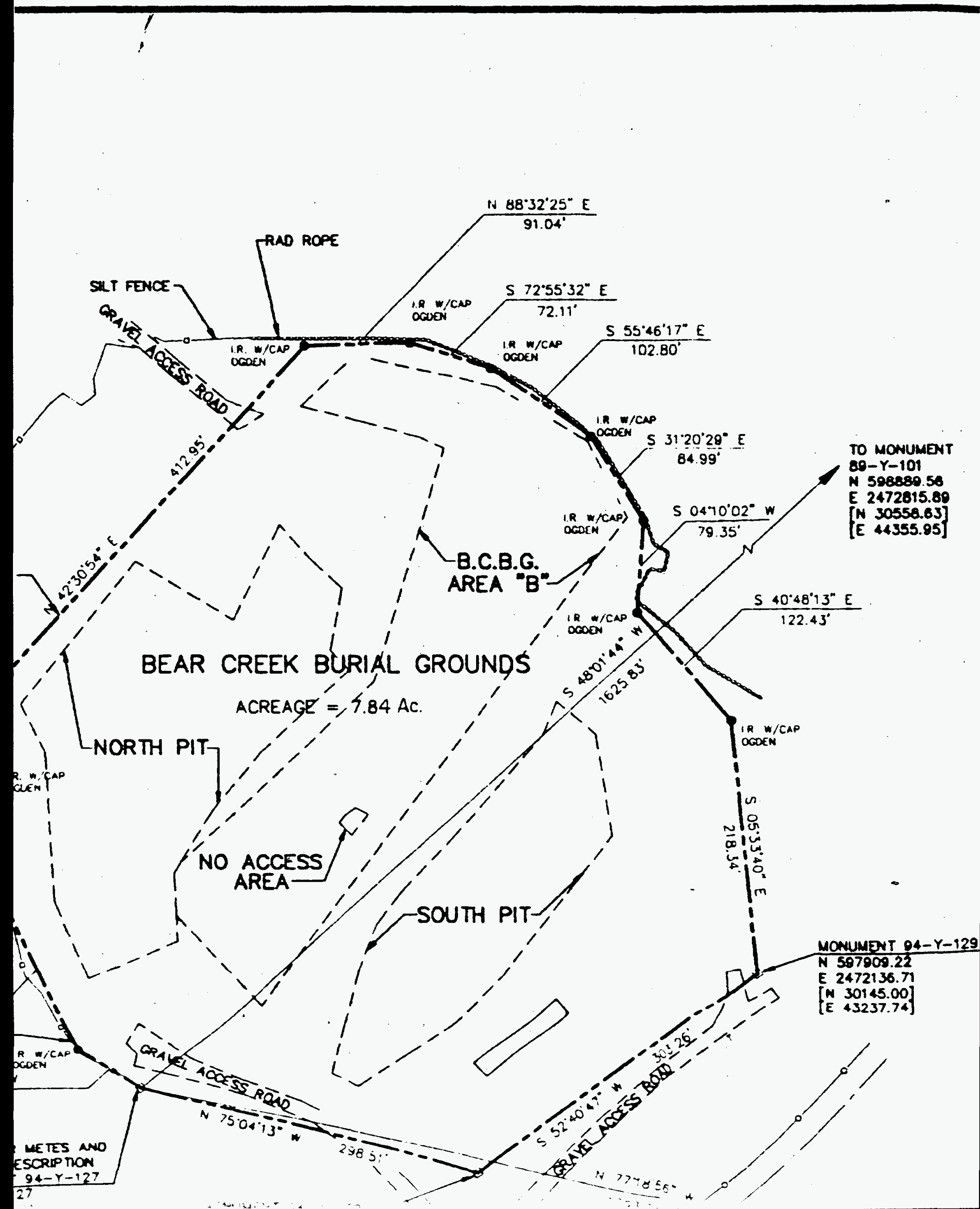


TO MONUMENT

80-Y-101

N 598880.56

E 2472815.89

[N 30558.63]

[E 44355.85$]$

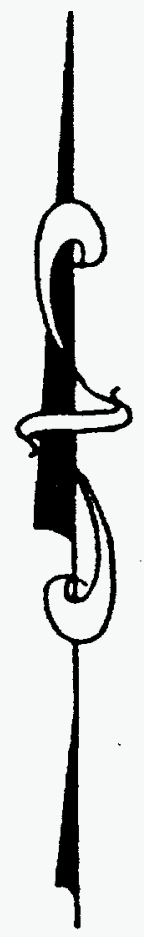

NORTH BASED ON TENHESSEE STATE PLANE COORDMNATE STSTEM NADOS (88). (SEE CENERAL NOTE 2).

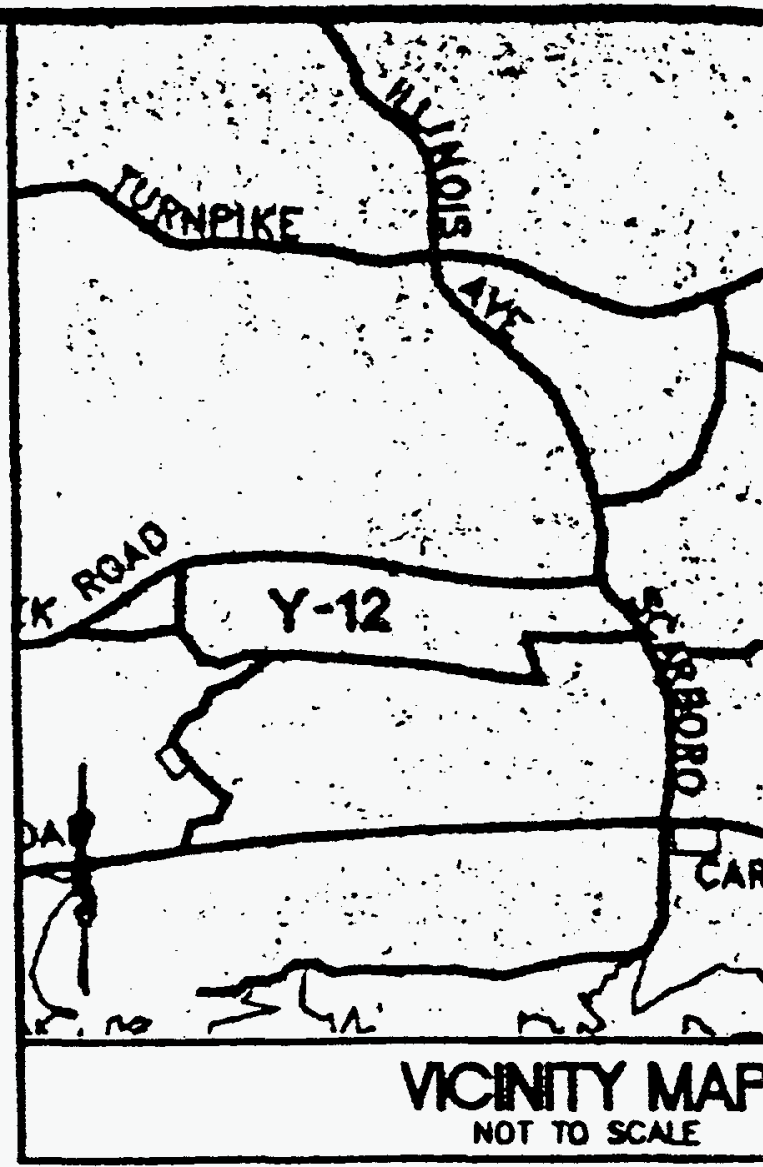

NOIFS:

The OWER OR OPERATOR Of the PROPJPTY CONTAMUnC

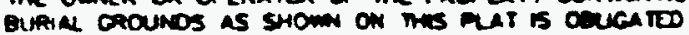

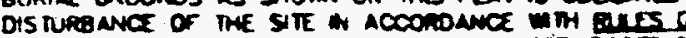

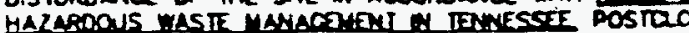
THF PROPFRTY ON OR IN WNCH HAZAFORIS WASITS RFE MUOWD to OSTURS THE NTECOTY OF ME FWM COVE OTHER COMPONENTS OF NHY CONTANMUONT STSTEM OA $n$ FACUUTYS MONITORENG STSTEMS UNUTSS THE OMAER OR APPROVA FROW THE COMWISSONER OF THE TENWESSEI ENMPONMENT NO CONSERVA TION UNOER THE PRE MOUS:

\section{WASTE REPORT}

GEAR CREIX DURA CROUNO'S (BCBC) WAUX-IN-PITS (NW

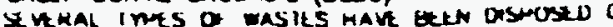
CACUNDS ARCAS. MEUDWE THE FOLOWHC (NOT L CEMERATIO VOUUE)

- terRous retuss mo uRamear

- OLs no coOnnts.

- surs.

- DEBRIS

- savoirs.

CDIRENCOAMUNC $\pi$ RAACETC ACO (COTA) - asarstos

- material comiaminated min Radocasotor

- wor vater ano

- kera hollow ouatar resoue.

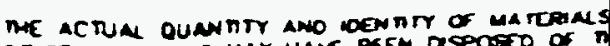

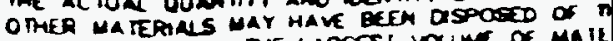

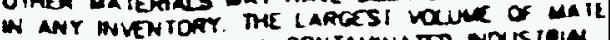

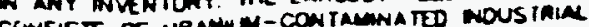
CUNSISTS OF URAMU RuEQLS)

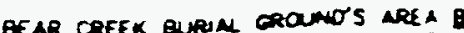

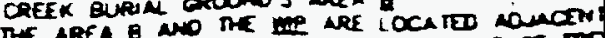

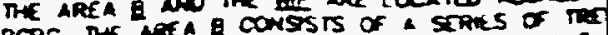

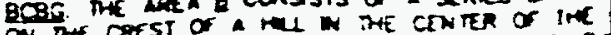

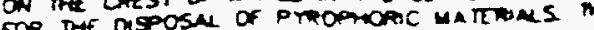
for $T$

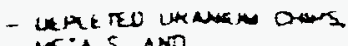




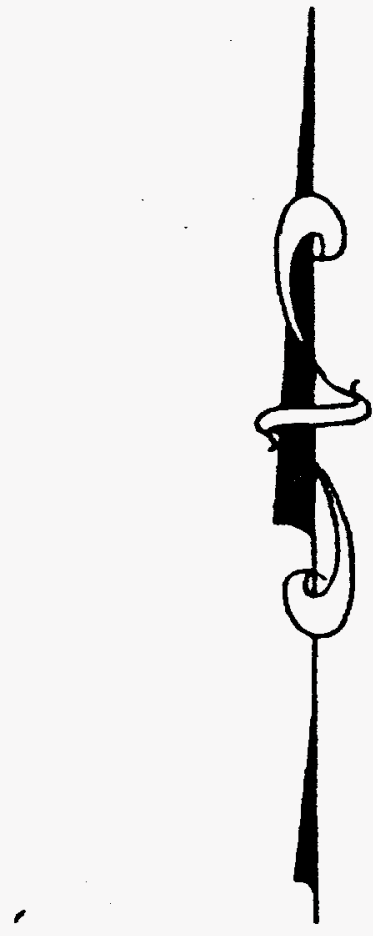

NORTH BASED ON TENWESSEE STATE PLANE COORDWNATE STSTEM NADO3 (88). (SEE CENERAL NOTE 2).

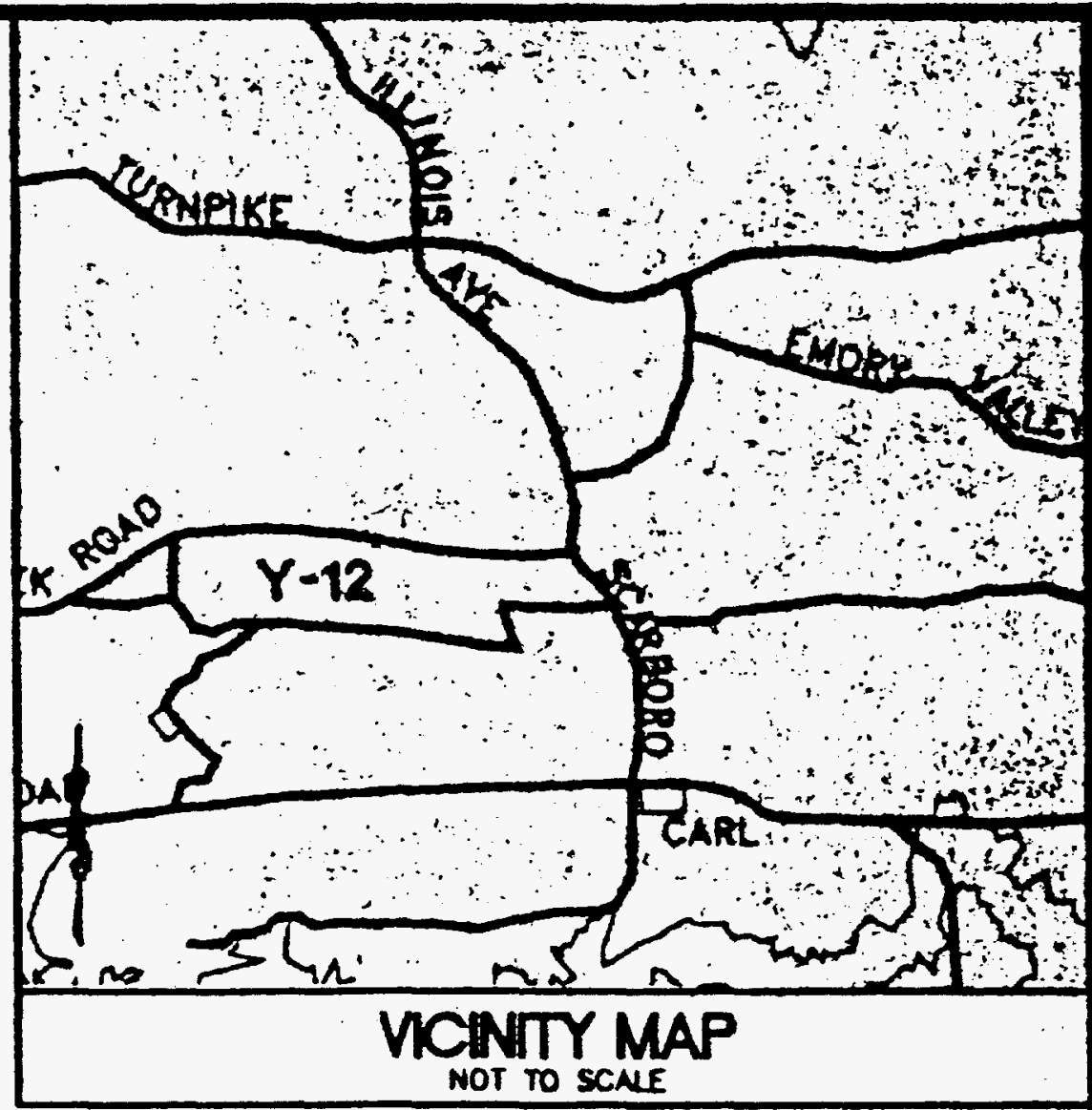

\section{NOIES:}

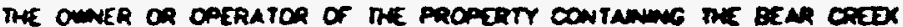

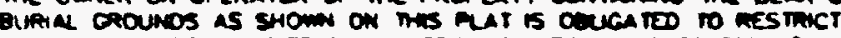

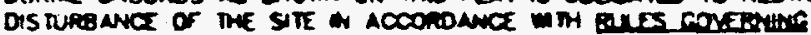

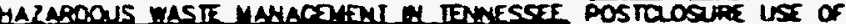
TAF PROPFRT ON OR N WHCH MAZAROMIS WASTIS RFMAM WUST NE VER ES

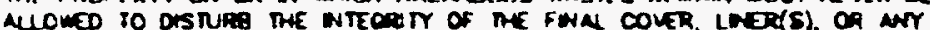
OTHER COMPONENTS OF NY CONTANAENT STSTEM OR NAE RNC RON OF THE

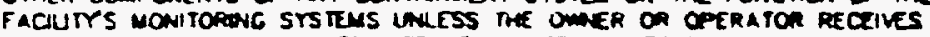
APPROVAL FROM THE COUMSTONER OF THE TENWESSE OEPARTMENT OF

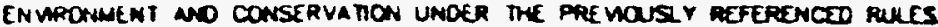

\section{WASIE REPORT}

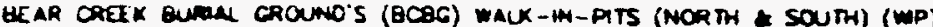

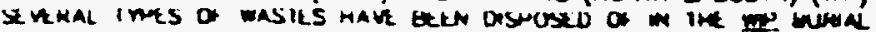

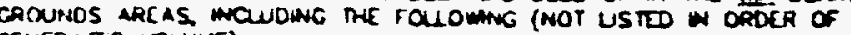
CEMRRATLO VOUHE)

- EERrous metas no URAmem

- OLS MD COOANTS

- Sers.

- Debars.

- savers

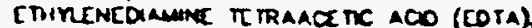

- asacstos

- haterial contameteo win Raocasotopes.

- mo water ano

- kerr hollow ouarar resoue

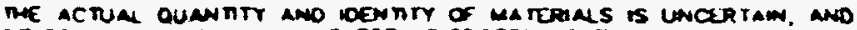

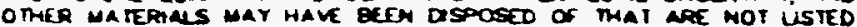

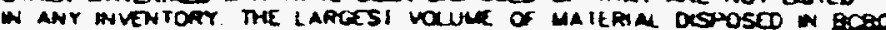

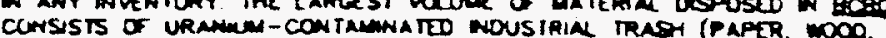
STEL Cass. AND pueary

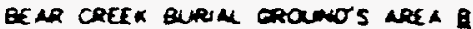

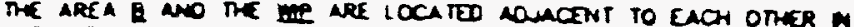

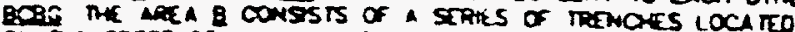

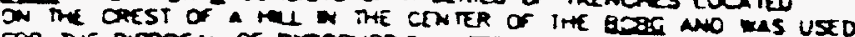

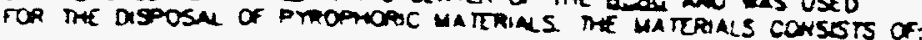




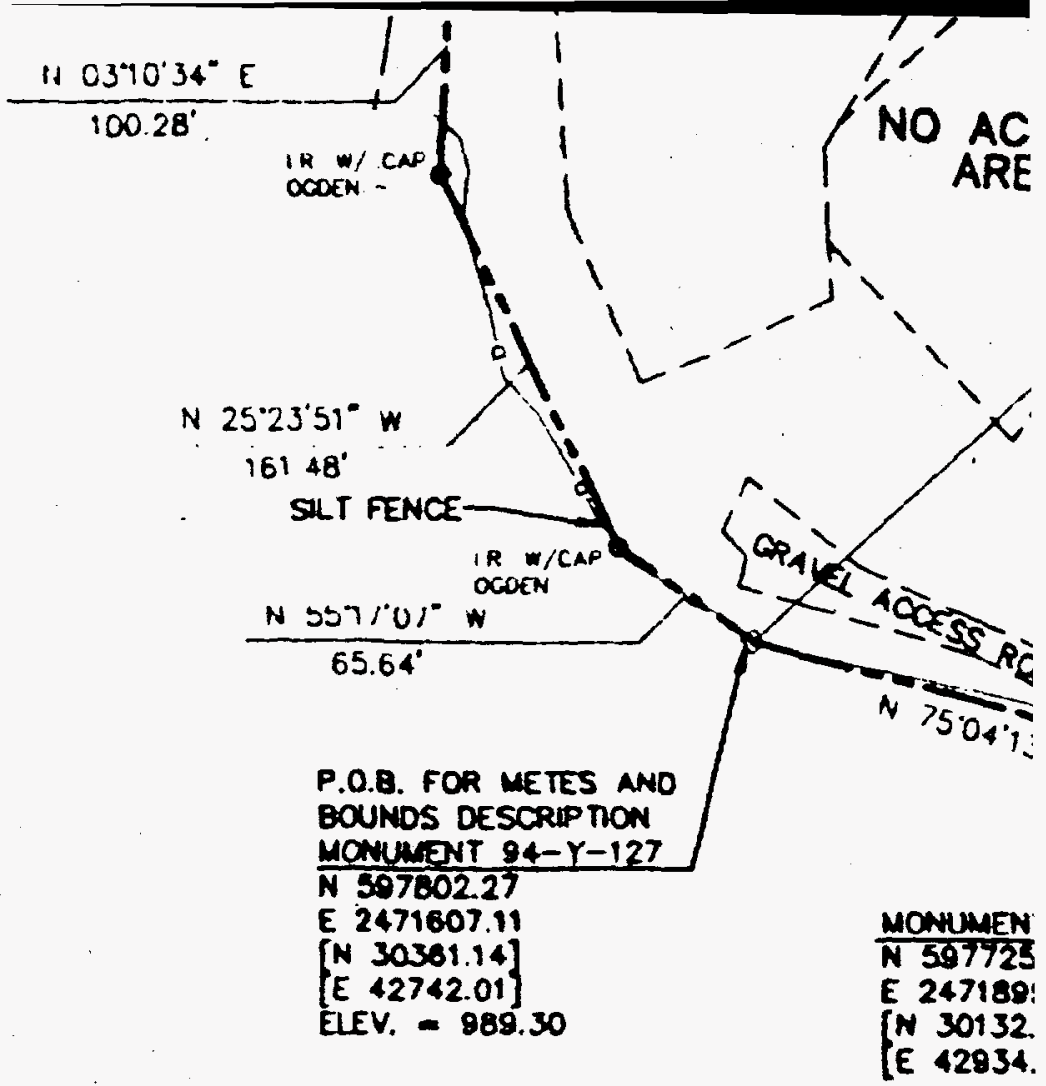

\section{DEED REEERENCE MEORMATIOA}

TE BCM OEEK BUPAL GRONO WNX-M-MIS MORM, SOUTM AMO AREA $B$

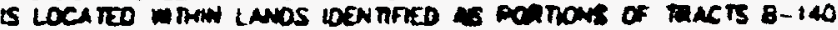

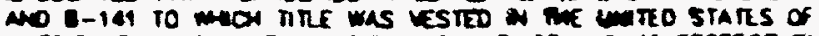

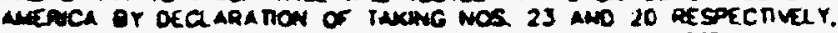
of CIV ACnON HO. 420 FILD FED. 2 1043 W TE UN TEO

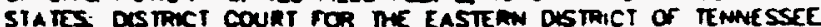

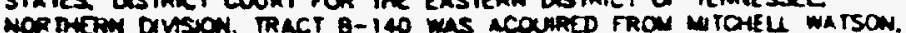

ET. UX. NOO TRACI O-141 was ACOUIRED FRON W. B. PETERS. EI UX

\section{CERTFGADON}

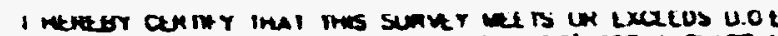

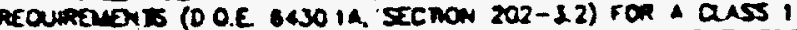

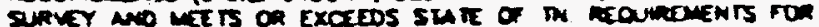

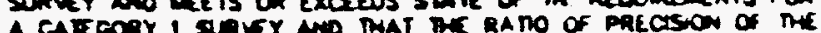

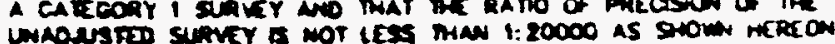

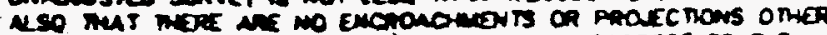

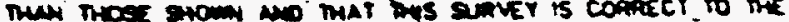

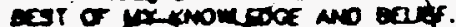
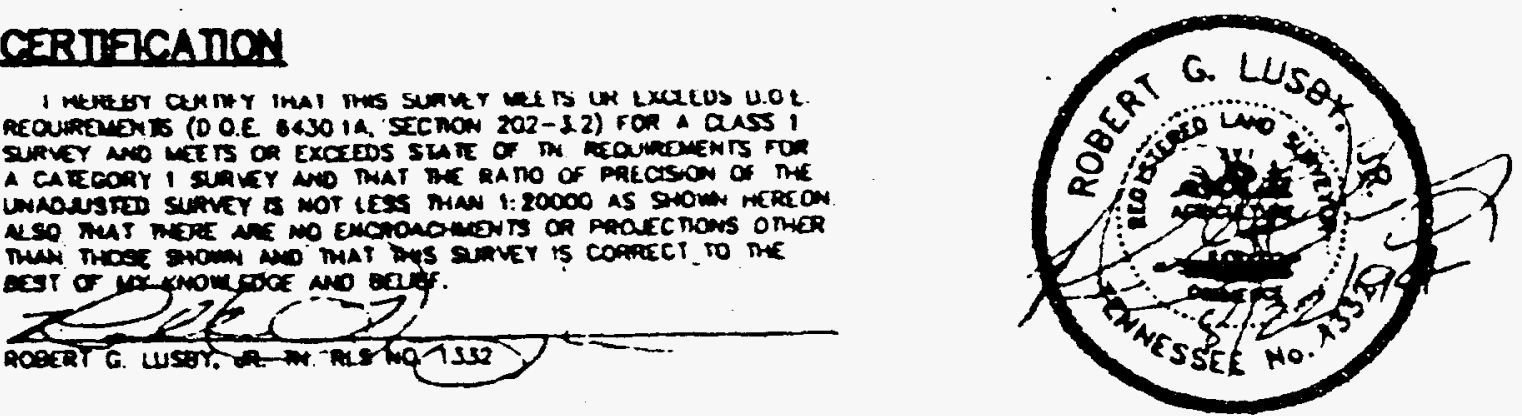
MONUNENT $94-Y-129$

N 597909.22

E 2472136.7

[N 30145.00$]$

[E 43237.74]

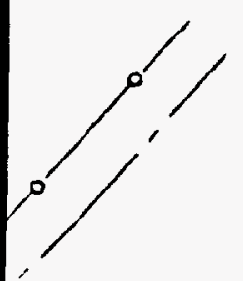

N 597582.22

E 2472673.69

[N 29552.73]

[E 43478.15]
TO MONUMENT

$09 / / 102$

BEAR CAEKK BUAN CROUNO'S (BCBC) WaLX-HYrukal ines o wasits mane beth ons CAOUNOS AREAS MCWDONC DE FOLOWM CINERATID VOUAKE)

- terrous metals ano uramer

- OLs no coovaris.

- surs.

- ospars.

- savors

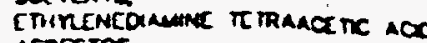

- asperstos.

- materiar contamina deo mim rivo

- mop vater ano

- Kerar hollow cunarar resoue

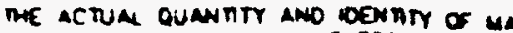

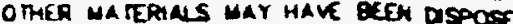
W ANY MNVENTOAY. TME LARGESI VQUNK CCANSISTS OF URAMUMAM-CONTAMMNATED MOU STEL. QNSS. AND RuBQUS?

QEAR CREEK GURM GRONO'S NREA

THE AREA Q wO TE WE WRE LOCA TED

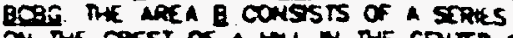
ON THE CAEST OF a HUL W THE CONTER

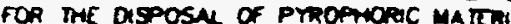

- Meple teo unanim ontr.

- Mins, aND

oxpoes.

\section{GENERAL NOTIES:}

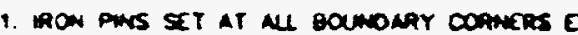

2 Ml coOronates Dastances ano deanungs

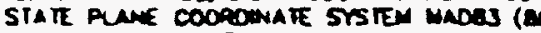

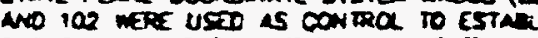

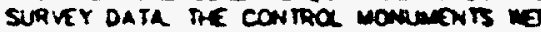

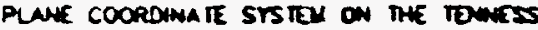
AOrF. (a) Referes to me rin in whe ENERCY STSTEMS (MANES) ESTABUSSED MOCE RESERVANON USENC valuES PUEUS

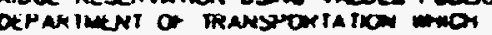
NUO LOCN PLANT GRTO MONUMENTS TO I Ne TMOOK (ICON)

3. COOROMATES SHOW W BAACKETS WAE W

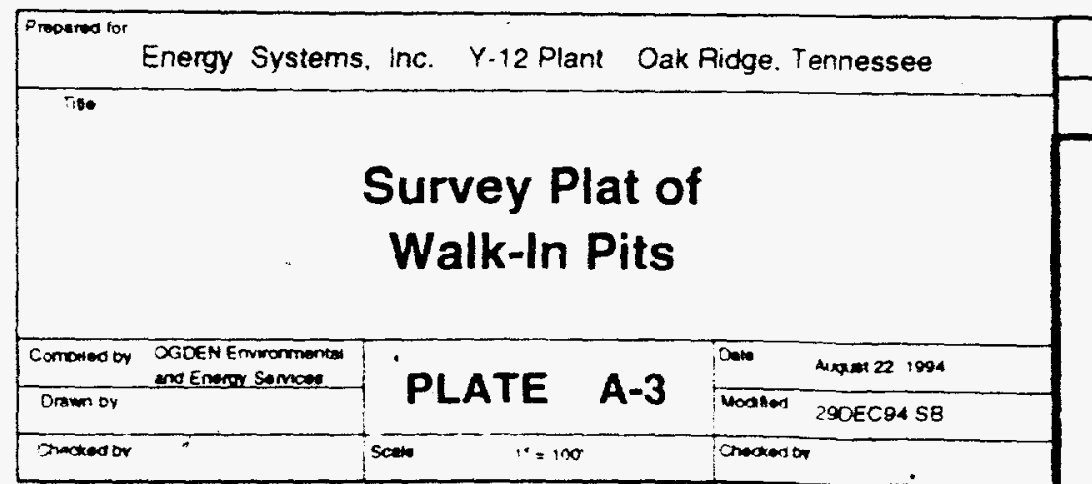

\section{GRAPHIC SCALE}

$100^{\circ}-100^{\circ} 200^{\circ}$

SCALE: AS SHOMn

PREP ARED FOR

FOR THE BEAR CREEK BI ANDERSON COUNTY, OAK

\section{DEPARTIENT}

PREPARED BY:

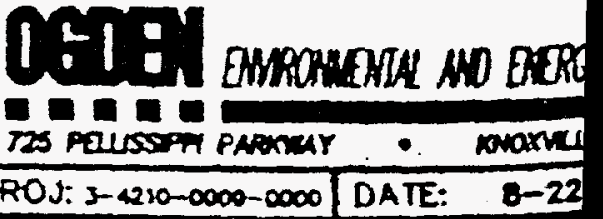




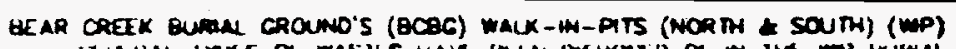

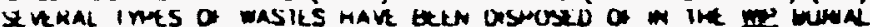

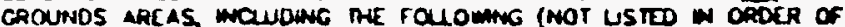
CENERA RLO VOUHE)

- FERROUS IETALS ano URAMIIA

- OUS nO COOANTS.

- SNis.

- Degris.

- savars.

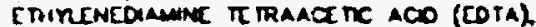

- Aserstos

- haterial contaninated min rapcosotores.

- mop varer ano

- kerar nollón ouarri resoue

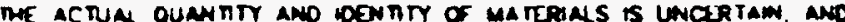
O MER WA TERALS MAY HAVE BEEM DSPOSED OF MAT ARE NOT USTED

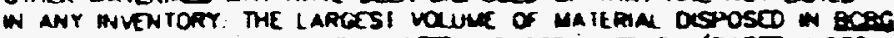
CONSISTS OF URAMUN-CONTALMNATED NOUSIAIAL TRAOH (PAPER. WOOO. STEL. QASS, ND RUBQL).

BEAR CREEK QURA GROWNO'S AREA B

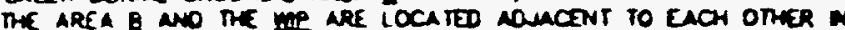

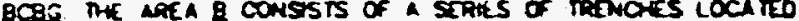

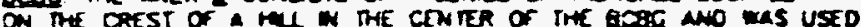

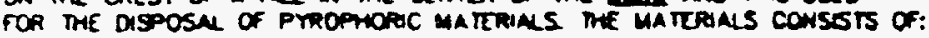

- UEPLE TEO UKANAM COMS.

- HTANS ANO

- oxpers.

\section{GENERAL NOTES:}

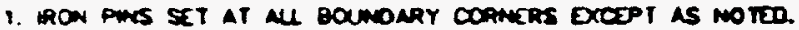

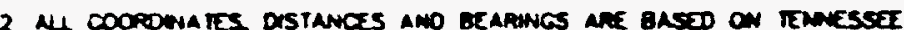

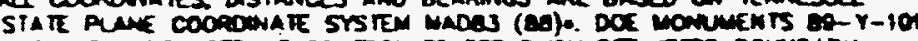

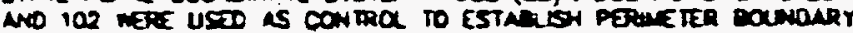

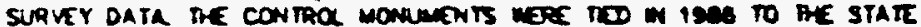

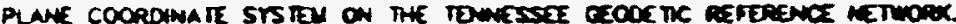

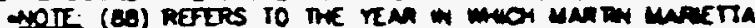
ENERCY STSTEMS (WAES) ESTAQUSTLD EPS WOMUMENTS on The ON

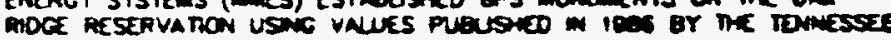

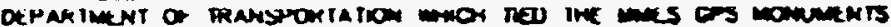

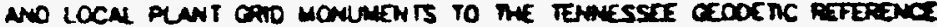
NET TOON (ICON)

3. COORDWATES SHOWN W BRACKETS ARE W TE Y-12 COAO STSTEM

tems. Inc. Y.12 Plant Oak Ridge. Tennessee

\begin{tabular}{|l|l|l|}
\hline & & \\
\hline DATE & REVSIONS & BY \\
\hline
\end{tabular}

Survey Plat of

Walk-In Pits

FINAL STE CLOSURE PARCE PLAT

FOR THE BEAR CREEK BURIAL GROUNO STE ANDERSON COUNTY, OAK RIDGE, TENNESSEE

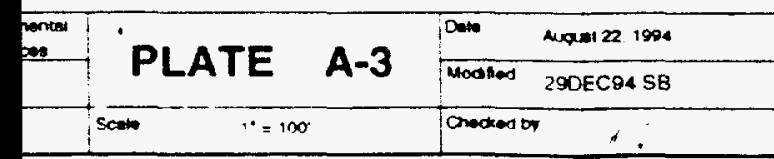

